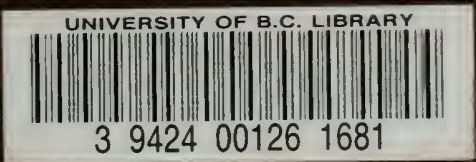

SICRAGE ITEN

FROCESSING-CNE

I P 1-F $19 \mathrm{E}$

U.B.C. LIBRARY 


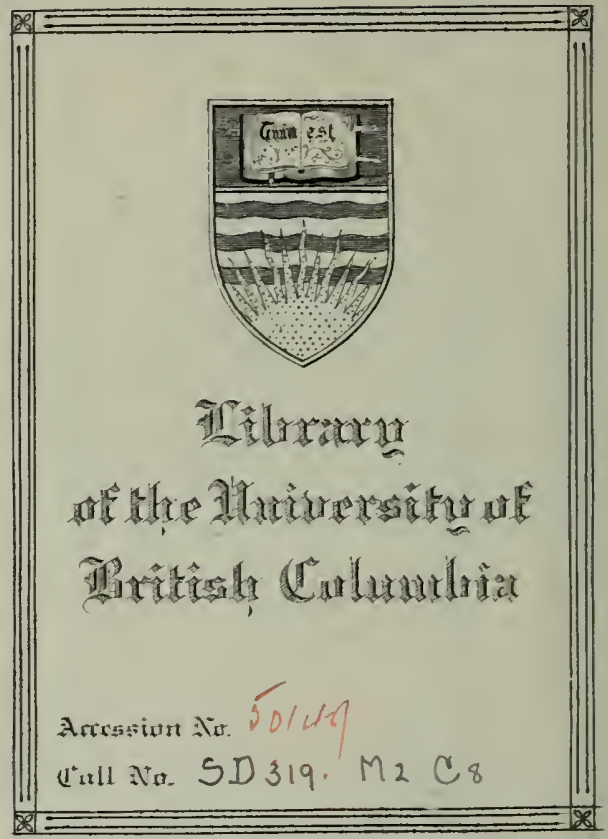




$S C H O O L$

$$
\text { FOREST EN GINEERS }
$$

IN SPAIN. 



\title{
$S \mathrm{CHOOL}$
}

or

\section{FOREST ENGINEERS}

\section{N S P A I N,}

\author{
INDICATIVE OF A TYPE FOR A
}

\section{BRITISH NATIONAL SCHOOL OF FORESTRY.}

\author{
COMPILEI BY
}

JOHN CROUMBIE BROWN, LL.D.,

Formerly Lecturer on Botany in University and King's College, Alerdeen; subsequently Colonial Botanist at Cape of Good Hope, and Profes:wor of Botany in the South African College, Cape Town; Fellow of the Linnean Society; Fellow of the Royal Geographical Society; and Honorary Vice-President of the African Institule of Paris.

EDINBURGH :

OLIVER AND BOYD, TWEEDDALE COURT,

LOXDON : SIMPKIN, JARSHALL, AND CO,

1886. 
- 


\section{P R E F A C E.}

Is the spring of 1877 I published a brochure entitled : The Schools of Forestry in Europe: a Plea for the Creation of a School of F'orestry in Connection with the Arboretum at Edinburgh, in which I submitted for consideration the opinion that with the acquisition of this Arboretum, and with the existing arrangements for study in the University and in the Watt Institution and School of Arts, there are required only facilities for the study of what is known on the Contiuent as Forest Science to enable these Institutions conjointly, or either of them with the help of the other, to take a place amongst the most completely equipped Schools of Forestry in Europe, and to undertake the training of foresters for the discharge of such duties as are now required of them in India, in our Colonies, and at home.

On the 15th of May, 1885, it was ordered by the House of Commons that a Select Committee be appointed to consider whether by the establishment of a Forest School or otherwise our woodlands could be rendered more remunerative. By this Committee valuable evidence was collected, and on the 24th of July they agreed to the following report:- "Your Committee are of opinion that at this late period of the session it will not be in their power to conclude their investigation; they have there- 
fure arreed to report the evidence already taken to the House, and to recommend that a Committee on the same subject should be appointed in the next session of Parliament." And this was done; but in like circumstances, and with like result. Meanwhile, at the meeting of the British Association for the advancement of science held in Aberdeen in the autumn of the year, the general Committee of that body adopted a resolution that Sir A. Taylor, Professor Bayley Balfour, Dr. Crommbie Brown, Dr. Cleghorn, and Sir John Lubbock, be a Committee for the purpose of considering whether the condition of our forests and woodlands might not be improved by the establishment of a forest school.

I was called to give evidence before the Committee of the House of Commons appointed last summer to consider this matter. In reply to a query then put to me I stated, amongst other things, that I could not name any School of Forestry which I could propose as a model for a Schnol of Forestry which would meet the wants of Britain, but that the School of Forest Engineers in Spain was one of a type which might be followed with advantage in the organisation of a British National School of Forestry if it should be determined to establish one in Edinburgh, which offered special facilities for the establishment of such a School.

The following compilation has been made to illustrate what is implied in the opinions which I then expressed.

I adhere to these opinions, but I consider that valuable suggestions which might be utilised in the organisation of a British National School of Forestry may be derived from a knowledge of what arrangements exist in other Schools of Forestry on the Continent of Europe than 
that specitied; and I have prepared for the press a companion volume on the Schools of Forestry in Germany, the Fatherland of Modern Forest Economy, and the land in which Schools of Forestry originated. In this I have given accounts of the Schools of Forestry in Saxony, Prussia, Hanover, Saxe Weimar, Hesse Darmstadt, Baden, Wurtemburg, and Bavaria; with notices of an exhaustive discussion of the relative advantages of having a School of Forestry in the country in immediate proximity to a forest in which the students might be exercised in forest operations, or of having it established in connection with a University, or some similar seat of learning; and of stations for experimental research and observation established at the sites of Schools of Forestry.

In connection with this intimation I may mention that in the Plea, \&c., to which I have referred, I have given notices more or less extended, of the existing Schools of Forestry in Russia, Saxony, Hanover, Hesse Darmstadt, Wurtemburg, Bavaria, Austria, Poland, Russia, Finland, Sweden, France, Italy, and Spain.

In the Journal of Forestry information is given in regard to the course of study followed at Hohenheim, in Wurtemburg, vol. i., pp. 81-87 ; at Carlsruhe, in Baden, pp. 394-398; and at Evois, in Finland, pp. 545-551, $701-$ 707. In regard to this last, details are also given in a volume entitled: Finland: its Forests and Forest Management. In a similar volume entitled: Forestry of Norway, information is given in regard to instruction in Sylviculture given in the Agricultural School at Aas; and in one entitled Forestry in Poland, Lithuania, and the Baltic Provinces of Russia, are given the code of regulations 
prescribed for the institution of Agriculture and Forestry at Novoi Alexandra.

It is my belief that a light will be found thrown upon any or all of these notices of Schools of Forestry if the reader have, previous to the examination of them, glanced at a volume published by me entitled: Introduction to the Study of Modern Forest Economy; and in connection with this, another entitled French Furest Ordinance of 1669 , with Historical sketch of Previous Treatment of Forests in France.

\section{JOHN C. BROWN.}

Haddingtox, 10th September, 1886. 


\section{CONTENTS.}

\section{PART I.}

Chapter I.-Origin of Corps of Forest Engineers in Spain,

Chapter II.-Origin and Development of School of Forestiy,

Origin of Schools of Forestry in Germany (p. 9); and in other Countries (p. 11); Spanish Ordinances regarding Schools (p. I3); Opening of School at Villaviciosa (. . 15); Derelopment of Programme of Instruction (p. 17) ; Removal of School to the Escurial (p. 22).

Chapter III. - School of Forestry in the Escurial,

Entrance Eramination (p. 25)-First year's Studies : Topography (p. 2S); Applied Chemistry (p. 2S)Second year's Studies: Applied Nechanics (p. 30) ; Geodesy (p. 31); Meteorology and Climatology (p. 33); Constructious (p 34)--Third year's Studies : Applied Geology and Mineralogy (p. 35); Applied Botany (p. 3i); Applied Zoology (p. 41); Sylviculture (p. 42)-Fourth year's Studies : Xilometry (p. 44): Forest Ordenacion (p. 14) ; Forest Industries (p. 45); Jurisprudence (p. 16) ; Political Economy (p. 47); Drawing (p. 47).

Chapter IV.-The Library, . . . . 48

Section I.-Books appropriate to Studies of First Year,

Sub-Section I.-Applied Mathematics (p. 49).

Sub-Section II,-Anplierl Chemistry (p. 49). 
Section II. - Pooks appropriate to Studies of Second Year, .

Sub-Secticn I.-Metcorology, Climatology, Stations of Observation and Experimental Research (p. 51).

Sub-Section II. - Construction (p. 59).

Section III.-Books appropriate to Studies of I'hird

Year

Sub-Section I.-Mineralogy and Geology (p. 64);

Sub-Section II.-Applied Zoology (p. 66).

Sub-Section III.-Applied Botany (p. 69) ; Excursion into the Field of Botany (p. 70); The Temperature of the Tree (p. 77); Topical Botany (p. 84).

Sub-Section IV._-Sylviculture (p. S6).

Section IV.- Looks appropriate to Studies of Fourth

Year, Xilometry and Forest Ordenacion,

Section V.-Boolis relative to Forest Industries,

Sub-Section I.--Preparation of Timber, Firewood, and Charcoal (p. 101).

Sub-Sectiou II. - Collection and Manipulation of Resin (p. 103).

Sub-Section III -Collection and Manipulation of Bark and Cork (p. 113).

Section VI.-Boolis relutive to Jurisprudence and Political Economy,

- Organisation of the Guvernment of Spain (p. 120).

Sectios VII.-General Forestal Literature, .

Cinpter V.-Forest Excursions,

Excursions (p. 145) ; Excursion to Gerona (p. 153); to Austria (p. 155); to Scandinavia (p. 155); to America (p. 156); to Algeria (p. 158); to Naples (p. 160).

Chupten VI.-Corps of Forest Engineers and Staff of Teachers, 


\section{PART II.}

Practical Arrangements in accordance with those in the School of Forest Engineers in Spain, suitalle for a British National Schoal of Forestry, . .

Chapter I.-Appropriate Site for a British National School of Forestry, . . . . 170

Advantages offered by Edinburgh (p. 1;1); Additions required (p. 173) ; Facilities for Practical Training (p. 175).

Chapter II.-Scholastic Arrangements,

Section I.-Conditions,

School nnder Science and Art Department of Committee of Council on Education, (p. 178) : Professorship of Forestry in University (p. 180); or in connection with Watt Institute (p. 183; or in connection with some Public Body (p. 1S4).

Section II.-Curviculum of Study, .

Object aimed at (p. 186); Teachers (p. 187); Students

(p. 189); Suggested Programme (p. 190).

\section{Section III.-Expense,}

Expense of such Schools on the Continent (p. 195); Expense of Royal School of Mines in London, and of Royal College of Science in Dublin (p. 198); Scholarships for Students in connection with these (p. 198); Expense of British Students of Forestry at Nancy (p. 200), and at Cooper's Hill (p. 201).

Chapter III.-Relative Importance to a School of Forestry, of Scholastic Surroundings, and of Adjacent Forests,

Prevalent Feeling in favour of Adjacent Forests (p. 205); Opinion of Dr James Brown (p. 206); Extent to which a different feeling prevails on the Continent (p. 212); Exhanstive Discussion of the Subject at Congress of German Forestal Authorities (p. 214.) 
Chapter IV.-Forestal Lilerature,

Limited Forestal Literature in Britain in Comparison with that of the different Countries on the Continent (p. 218); Late Increase in the Publication of such Works in Britain (p. 220); Reason of past want of Interest in Moderu Forestry ( $\mu .230)$; Notices of Pecuniary Returns (p. 232.)

E R R A T A.

$\begin{array}{cc}\text { PAGS } & \text { LINE } \\ 2 & 12 \\ 5 & 9 \\ 7 & 11 \\ 7 & 37 \\ 14 & 19 \\ 19 & 9 \\ 21 & 27 \\ 55 & 14 \\ 55 & 23 \\ 58 & 26 \text { and } 27 \\ 58 & 28 \\ 58 & 38 \\ 67 & 17 \\ 69 & 32 \\ 84 & 9 \\ 86 & 18 \\ 87 & 15\end{array}$

ror
de
Ley La
Arices
Francesco Goercia
los Horas
jardine
unsabo
Frederico de Botello
Torea
Jldefonsa
Fomenta
Guadalajara
adeocuardos
Seriex
Sciencas
des
Pamāgua

REAB

Don.

La Ley.

Arias.

Francisco Garcia.

las Heras.

Jardin.

no sabe.

Frederico de Botella.

Teoria.

Ildefonso.

Fomento.

Segovia.

adecuados,

Sereix.

Ciencias. del.

Paniagua.

Page 167.-By later information, I learn that now the allowance for travelling expenses is to students $40 \mathrm{reals}$, or $8 \mathrm{~s}$, and to professors 100 reals, or fll a-day, when on excursions. 


\section{SCHOOL OF FOREST ENGINEERS I N S P A I N.}

\section{CHAPTER I.}

\section{ORIGIN OF A CORPS OF FOREST ENGINEERS IN SPAIN.}

THE treatment of forests in Spain for many ag's seems to have differed little from that of the treatment of forests in other countries, differing chiefly in this: for while in many other lands the disposition to practice a wasteful destruction of forests was to some extent held in check by measures adopted by kings and nobles to secure for themselves what are called the pleasures of the chase, and this leading them to punish unmercifully the destruction by others of trees which afforded covert for their game, - this loes not seem to have been the case, or the case to the same extent, with the successive rulers of the Peninsula, who were all of them of different races from the later conquerors of Central Europe.

The present encteavour to secure the conservation,economic exploration, improvement, and so far as practicable and rxpedient the replenishing and extension of existing forests in Spain may be said to have originated, or taken a fresh departure in the issue of General Ordinances in reference to these in 1833. There had been previous legislation in regard to the forests; and some of the laws and official instructions which had been issued were not unimportant. Among those deserving of notice are such issued by Don Fernando and Donna Isabel in 1496, and others by Don Carlos 1, and 1)onna Juana in 1518. And a memoị on 
the then state of agrarian law by the illustrious Jovellanos, published towards the close of the last century, made manifest the necessity which there was for a development and improvement of the agricultural capabilities of the country, and arrest of the bad administrative management to which were being subjected the extensive but fast disappearing masses of the public forests. It was published originally in 1796; successive editions appeared in 1814 and 1820, and yet another edition followed in 1834. It is entitled Informe de la Sociedad Economica de Madrid, al Real y Supremo Consejo de Castilla, en el Expediente de ley Agraria Extendido por su Individuo lle Numero de Melchor Gaspar de Jovellanos a N'ombre de lu Junta Encargada de sa Formacion y Con Arreglo a Sus Opiniones.- Statements of the Economical Society of Madrid to to the Royal Council of Castile in regard to the Agralian Law, prepared by one of their number in the name of a Committee charged with the work, and in accordance, with their views.'

The edition of 1820 is considered the most trustwor thy of the earlier editions, as it was prepared nurler the auspices and direction of the Economical Suciety, following most scrupulously the original, corrected by the author, so as not to reproduce inaccuracies which hail appeared in other editions.

Amongst points discussed, which relate more immediately to forestal matters, are those connected with commons, lands belonging to communal cuuncils, and public forests, which, with some trifling exceptions, it was at that, time considered would be best protected from destruction by their passing into the hands of private proprietırs.

It is a prevalent opinion amongst students of forest science that while coppice woods may be exploited by private proprietors, without detriment to public interests, timber forests, and more especially timber forests from which are expected trees of very large growth, can only be satisfactorily administered by the State. It has thus come to pass that importance has been attached as a point of 
some interest, to what were the views of Jovellanos on this matter.

In a Catalogue Raisonné prepared and printed for private circulation, by Ilno Sr. Don Jose Jordana y Ilorera, of upwards of eleven hundred books, MSS. and charts in Spanish, original or translated, bearing upon forest science, the author writes thus of a treatise included in a collection of published works by Don Gaspar Melchor de Jovellanos, entitled Kepresentacion de la Villa de Gijon para que se prorogue el arbitrio de vino y sidra para Fuentes, Calles y Plantios:- For this work we are indebted to the illustrious author of the Informe Sobre $L a$ Ley Agraria, which, notwithstanding its unpretentious appearance, is one of the greatest importance in determining precisely what were the opinions of that enlightened patriot in regard to the nature, the advantage to the country, the utilisation, and the possession or temure by the State of the public forests, in regard to which many, misled it may be by the brevity or conciseness of his statements, have supposed that he spake doubtingly, rather than with certainty, in regard to the question of the absolute and entire alienation or sale of the forest possessions of the country. From the text of the Representacion it is apparent at least that his opinion did not go so far as this, but rather that on the contrary he assigns to public forests advantages, aud a utilisation of a national character impossible to be obtained from forests held only in the interest of a private proprietor.' And he remarks in regard to the Representacion:- 'One of the most noteworthy paragraphs in it is the following:-Nor is less certain the necessity of creating on the approach to this town a plantation of pines on the extensive sand plain stretching away to the east and the south, the sand composing which is kept in continuous movement by the wind, enters the streets and accumulates in them, obstructing and embarrassing the public way to the great trouble of passengers, and the great discomfort and annoyance of the inhabitants. 
'It is the case that with a view to remedy this evil there have been constructed protective banks, in regard to which this town addresses a separate representation to your Highness; but much more important would be such a plantation of pines as has been spoken of which would be productive of two great benefits-one arresting and breaking the force of the winds, and the other clothing and solidifying the ground, delivering this beantiful town for all time coming from an enemy which has been destructive to it in many ways, and proportionally producing an abundance of wood so necessary at the entrance to a port which has its little shipbuilding yard, where are being constructed continuously boats, pinaces, launches, and other vessels used in fishery and commerce.

'This is the more desirable because it would lead the town to extend other plantations in its immediate vicinity, for which it holds lands more extensive and well adapted for the purpose than may be imagined, affording protection to the new highway which is being constructed by orders of his Majesty; anıl giving shade to the new promenade and canals of the Humedal, made by permission of your Highness; and crowning with trees the forest of Santa Catalina, which protects this coast town on the north.

'All of these plantations, and many others which might he marle in the vicinity of this town, were proposerl to onr Town Council by our compatriot D. Gaspar Melchor de 'Jovellanos.'

It has heen for many years past a subject of kcen controversy, I may say of bitter dispute, between the Government and the students of forest science in Spain, whether it would tend to the saving or the ruin of the country to alienate the State forests, which, it is alleged, would almost rertainly issue in the destruction of them; and it supplics to the opponents of alienation a sentimental satisfaction to find that Jovellanos, to the pullication of whose Informe solve ley Agraria is attributerl the modern develnpment of forest science and forest economy in Spain, of whom it had heen alleged thathe was opposed to their views, was 
really at one with them. What however chiefly interests us is that this work of Jovellano's marks the rise of the present interest in forestry manifested in Spain.

In a work by Sr. Don Francisco Garcioa Martino, entitled Los Montes y el Cuerpo de Ingenieros en las Cortes Constituents - the Forests and the Corps of Forest Engineers in the Cortes and Legislative Assembly, the author, having referred to the work, proceeds :- The well-remembered luforme Sobre ley la Agraria of the distinguished Jovellanos produced a profound sensation in the beginning of the present century amongst the illustrious men of the country who realised the necessity of developing more fully the productions of our soil. The doings denounced in that celebrated document, with impreguable proofs of the vices inherent in the administrative management of our public forests, led to the serious consideration of that department of spontaneous products, which, with the abrogation of certain ordinances relative to the marine trade, were left abandoned and at the mercy of interested persons, and the ever-increasing pecuniary necessities of the municipal proprietors. Under the inspiration of the views of Jovellanos, they broke the fetters which preveuted liberty being enjoyed by agriculture. Thus was cxtended its sphere of action; but under the pretext of couvenient, useful, and even necessary forest clearings, there were committed such abuses in the forests, and our best forest masses were felled in such a way that the Guvernment saw itself under the necessity of legislating anew in regard to forest property, and of doing so iu accordance with the prevailing views of the day. Reformed France and cultured Gerinany set the example of restraining and repairing destructions which ignorance and administrative errors on the one hand, and wars and political confusion on the other, had produced in their furest riches.'

Sr. Martinos, in his introduction to this work, having 
alluded to the iraportant measures which had been previonsly adopted with a view to the development of the agricultural capabilities of Spain, to the good service which had been done by the several corps of engineers, and to what more might have been done, writes:- The law of the 22nd December, 1833, promulgating the general ordinances relative to forests, recognised the fict of the progressive destruction of these, and to meet them created a General Directory, to the charge of which were committe $f$ all those denominated public forests. The Admiralty lost then all the privileges it had previously exercised in regard to inspection, markiug and appropriating trees. This was a reasonable and just arrangement; but on the other hand the interests of the State were doomed by the limitation in Art. 24 that no other proofs will be admitted beyond authentic titles of proprietorship and uninterrupted possession for more than thirty years; which is a period far too brief in a matter pertaining to lands without fixed boundaries, and abandoned from remote times. Moreover, while there is mauifesterl an interest in the proper regulation of this branch of the service in these ordinances, comprising in all $\mathbf{2 3 6}$ articles, of arrangements in regard to administration, conservation, sales, felling, ntilization, policy, legal proceeding:s and penalties, there is apparently a lack of sound doctrine and of special knowledge of the matter in hand. It is a collection of practical :ules, some of them contradictory and others impracticable, but they tended, beyoud all doubt, to restrain abuses by imposing severe penalties for these. It is an almost literal translation of the French code, applied without sufficient study to our country; it opened the door to great abuses; and it was the occasion of no small destruction of the riches, the conservation of which it was designed to secure.'

What was now felt to be of imperious necessity was that those employed in this department should possess the requisite special knowledge. 'Io meet this it was there 
were issued special decrees on the 30th April and on the 1st May, 1S3.. It was said in Art. 7 of the former: - There shall be created in the corps of the civil engineers other two bodies (besides those of roads and of mines), geographic engineers and woodland forest engineers, so soon as the formation of primary schools of both shall admit of their being established.' 'The second postpones till the 1st of October following the creation of a special school for forest or woodland engineers, under the direction of the inspector of forests, Don Sandalio de Arices; and in Art. 7 it says:- When it shall be the case that there shall be created a corps of woodland or forest engineers, the director of the school shall be assigned rank and position in this, with due consideration of the services which up to that time he may have rendered.'

The civil war, and other matters of greater importance demanding attention, prevented the realising of this patriotic purpose at this time. But subsequently both purposes were carried out; and in studying the general question of forestry in Spain we find that the development of the School of Forestry, La Escuela especial de Ingenieros de Montes, and that of the corps of forest engineers, Cuerpo de Ingenieros de Montes, were collcurrent, each reacting upon the other, the instruction and training received in the school qualifying the members of the corps to make a progressive advance in the discharge of their professional functions, and this making new demands on the teachers of aspirants for such appointments. Thus, in marked parallelism, may be observed what is stated in regard to the development of the School of Forestry in a work by Sr. Don Carlos Castel y Clemente, entitled Noticia Sobre la Fundacion y Desarrollo de la Escuela Especial de Ingenieros de Montes: Notice of the Foundation and Development of the Special School of Forest Engineers, and in the arguments of the treatise by Sr. D. Francesco Goercia Martino, entitled Les Montes y el Cuerpo de Ingenieros en los Cortes Constituents. 


\section{CHAPTER II.}

ORIGIN ANU DEVELOPMENT OF THE SCHOOL OF FORESTRY.

Tне C'uerpo de Ingenieros de Montes, or Spauish Corps of Forest Engineers. is recruited exclusively from the Schnol of Forestry, Escuela Especial de Ingenieros de Montes.

Such a school was instituted by decree of the 1st May, 1835 ; but unany modifications were subsequently marle in the arraugements and organisation, more especially in 1843 and 1846, when the school acquired something of the development which it tiow presents as a State institution under the Minister of public works aud the Director General of public institutions. It was for a considerable time located at Villaviciosa d Odon, near Madrid ; but in 1869 it was transferred to one of the buildings pertaining to the palace of the Escurial, not far from the Sierra Guadarama, alsout two hours' distance by rail from Madrid. To Sr. Don Carlos Castel y Clemente we are indebted for much information in regard to the early history of the diffusion of forest science in Spain by schools of forestry. In the lattcr end of 1876, in accordance with instructions given to him, he undertouk to collect information which might serve as the basis of a memoir on the subject; and in the fullowing year the substance of this was published by bins in a brochure entitled Noticia Sobre la Fundacion y Desurrollo de la Escuelu lispecial de Ingenieros de Montes, in the introduction to which honour was done, as was most inect, to Sr. D. Bernardo de la Torre Rojas, fuunder, and fur many years Director of the first school of forestry in Spain, the acknowledged 'father of the Spanish School of Furestry.'

After sketching kriefly the reckless destruction of forest 
wealth in Central Europe in byegone times, to arrest which was again and again attempted by legislation in France and other countries, but with little effect, he refers them to what was done in Germany :-

'In the seventeenth century originated in some of the States of Germany the application of technical science to the treatment of forest masses. T'he rules, the aphorisms, and the whole of the directions which are compressed in the forestal knowledge of the ancients, are principles indefinite, olsscure, micertain, unconnected, destitute of method or systematized relations. Moser created in 1757 the tirst body of systematic teaching on the subject; and to the impulse given to this by him, and the weighty energy of Langen, Laspar, Zanthier, and others, are we indelted for the formation of the first plans of scientitic treatment of forests begun in $173 \mathrm{~L}$ in the forests of the Dukedom of Brunswick. He, in his time, Langen baving been the first to do so, perceiving the necessity of entrusting the management of the forests to a specially educated and trained body of officials, possessing all necessary knowledge and information, with a view to raising up a body of such men, established the first school of forestry in Wernigerode in the year 1772 . But others consider as the first school that founded by Zanthier in Ilsenberg, which was followed some years later by the establishment of that by Haase in Lanterberg, that which G. Hartig founded in Hungen in 1791, that founded in Zillbach by $\mathrm{H}$. Cotta in 179.5, and various others, all due to the efforts of individuals, and manifesting that essentially practical character which was so requisite to meet the requirements of the time and the conditions in which the distinguished founders were placed, but they lacked means which would allow of there being given to them the influence and development which became needful.

'Contemporaneously with the schools there were produced also new methods, or systems of exploitation; and the names which have been cited are those of men who proved authorities of the highest rank, who have opened 
up new paths in forest study. For me it is impussible, nor does space permit me, to produce a chronological and critical narrative of the principal phases through which the newlorn forest science passed in its evolution and successive development; fresh in the memory of many in Spaiu must be the remarkable articles written under the title, Sistémas Forestales, by the erudite Forest Engineer, His Excellency Sr. D. Agustin Pascual, the first Spanish writer on dasanomy, and formerly professor in our Schoul of Forestry, to whom it is enough that $I$ thus refer while passing on to state succiuctly the new form, and report the multiplication and general organisation of forestal schools which occurred in Germany and in some other countries in Europe.

'The primary organisation of the schools fuunded in Ilsenberg, Wernigerode, Lauterberg, Hungen, Zillbach, Walterhausen, Rottenhaus, Castell, \&c., in the period from 1766 to 1805 , was that of several other private centres of iustruction, which died out with their founders, or suffered the fate which befell these in the course of their existence. All these made themselves remarkable by the great impulse and development which they gave to the diffusion of forest seience, and by their having raised up a numerous and distinguished body of men to assist and direct at a later time the work of bringing into order the forests of the districts in which they were situated. There stands ont promiuently amongst all these the school founded by Cutta. He, being charged with the reduction to an orderly condition of the forest of Fishbach, spent some years in the execution of this work, during these years giving theoretic and practical instruction to the young men who assisted him there: thus was instituted the new centre of forestal instruction of Zillbach. Such reputation was acquired by this establishment of modern times, that in 1795 there was granted to it a subvention from the State, by means which Cotta was enabled consirlerably to augiuent the means available then for the prosecution of study. In 1810 Cotta was appointed 
Director of forest management in Saxony. $\mathrm{He}$ at once perceived and pointed out the lack - which existed of a skilled staff of officials, who should execnte and assist in the execution of his projects, and with a view to meeting this desideratum the forest school of Zillbach was transferred to Tharand in 1811, and was ceded to the Government on the 12th of May, 1816. Converted into a Government academy, and furnished with all necessary resources, the school of Tharand, devoted to the instruction of the forest cngineers of the State, very soon flourished beneficently, attracting to study there the studious youth of many different countries, and serving as the sharp edgre of a wedge for the general diffusion of those truths which, spreading themselves a little latter in different countries, proved the occasion of there being opened other schools which take pride in calling themselves daughters of the Saxon academy.

'In their turn, in Austria and Russia-nations which, if they did not take the first step, followed at once the advancing march of the States of Gerinany - there had been organised Schools of Forestry ; those in A ustria having the character of a private establishment in the beginning, but those of Russia being Government institutions from the first. Amongst those, the first established - that founded in 1770 by Ehrenwerk in Rotherhaus, in Bohemia-continued till 1791. This was succeeded by another, established in the beginning of the present century in Kruman; aud coincident with its appearance we meet with the schools of Eisgneb in Moravia, Eisgenstadt in Hungary, and Gratzen in Bohemia.

'Passing from private seminaries to public and Government institutions, there were founded the schools of Datschetz in Moravia, and that of Plass in Bohemia, opened in 1823 and 1880, in which there is some Government intervention, but this is very limited. When the Government was once convinced-as was the case likewise with the Government of Germany-of the urgent necessity there was for entrusting the administration of 
forests to a staff of officials cndowed with special scientific knowledge, they arranged in 1805 the opening of a cuurse of practical instruction in sylviculture in Purkersdorf, near Vienna; and subsequently, in 1813, increasing the staft of professors, and with a well-considere' plan of instruction, this school was transferred to Mariabrun, not far from the capital of the empire. In 1897 the plan of study was changed, and the suljects of study werc divided into four semestres, or half-year sessions; ultimately, iu 18.5., this was reorganised by distributing over three years the study of the different prescribed subjects which comprised the course followed by forest engineers.

'Other schools exist in Austria, due-some to the initiation of private individuals, others to the action of provinces, and most to the exertions of forestal associations, which have increased in that country. Such, for example, is the school of sylviculture in Weisswasser, that in Aussee, that of Kreuz, and others.

'A faithful imitator of Germany, and endowed with a great amount of practical spirit, Russia in the beginning of the present century introduced the forestal instruction imported from the academies which were founcied years before by those who well merit the name of Fathers of the present forest science. The schools of Zarsko-Selo anl Kafelskoy, created in 1803 and 1804, propagated the movement which was being initiated by the successful scholars of the German schools. These being reorganised in 1813, the school was removed to St. Petersburg, where, in 1829, the new school received the name of Forest Institnte, and was some time later made more complete by the establishment of a school of practical forestry at Lissenoy. Russia has now additional schools, which may be reckoned amongst the means available for forestal iustruction. These are callel schools of the Steppes, amongst which, deserving special mention, is that opened in 18.2 in Analol, the highest lying and most barren spot in the Steppes of Ekatherinoslav; the primary object of which is to educate and train sylviculturists for the 
management of steppe lands of that extensive district.

'In regard to France, into which the ideas prevailing in Germany penetrated without difficulty, they then perceived also the necessity of entrusting the administration of public forests to a staff of officials possessed of a knowledge of the several departments of forest science; and, to secure this, they instituted in Nancy, in the year 1824, the school where the forest engineers thenceforward have received instruction. The first director of this school, M. Lorentr, having been educated at T'harand, the school was formed after the inodel of the earlier schools of Germany, and its organisation was accordingly similar to that of those schools; and it has long inaintained a well-deserved consideration for the ztal, and energy, and work of its professors.

' Such, in rough outline, is a sketch of the history of forestal instruction in Europe, reflecting the dominating ideas of different nations in which schools of forestry had been established, when first there was heard in Spain a voice with authority proposing to open for her also a road which might lead to the consideration and restoration of her diminished forest riches.'

Sr. Castel, in his treatise on the origin and development of the school, writes, in accordance with what has been stated in the preceding chapter in reference to the General Ordinance of 1833 , cited in the preceding chapter, as issued to prevent a progressive devastation and destruction of forests in spain. In reference to the General Ordinance of 1833, he says: "While these General Ordinances put an end to some vicious practices and privileges which could not be sustained, and created a General Directory, to the charge of which were committed all the forests now designated public, they did not break with the traditions and proceedings of established usage coming down from the olden times, manifesting a lack of special know. ledge of the matter in hand, and great if not absolute 
ignorance of the good doctrine which found its birth, some fifty years before in the schools of Germany, and had cast its dawning light upon the northern slopes of the Cordilleras of the Pyrenees.'

'I'wo years later, by Royal decree of 30 th April, 183.5, it was established, that within what was called the corps of civil engineers, there should be established a department designated Inspector of Woods, so soon as the creation of the necessary school should admit of this being efficiently organised; and next day (1st May), there was prepared a Royal decree, according to which the said school of forest engineers was established in the capital of the kingdom, in October of the same year, under the direction of Don Antonio Sandalio de Arias.

The year, however, closed without the project being realised, and the subject might seem to be furgotten. But some years later a son of Cotta, who with Hartig founded the original school of forestry in Saxony, was invited by Senor Don Martin de los Horas, Intendente de la Real Casa y Patrimonio, to come and organise a scientific management of the forests of the Royal patrimony. He could not come: and to meet the more pressing requirements of the case two young men were sent, at the charges of the Royal treasury, to the forest academy at Tharand, to go through the course of study required of them as furest engineers; and on 16th March, 1S43, there was issued by the Regent of the kingdom a decree ordering anew the establishment in Madrid of a special school of forest engineers, and practical schools of sylviculture, land surveying, and mensuration, in the provinces of Cuenca, Huesca, Jaen, and Santander. Along with this decree there were issued regulations for the schools, but like the first attempt to accomplish the same object this seconil proved abortive.

A Royal decree, issued on the 1Sth Norember, 1S 46 , had, however, happier results, and on the 10th January, 1847, by Royal order, Senor Don Bernardo de la Torre Rojas was appointed Director of the projected sc.iool. 
Regulations were prepared,and professbrs were appointed to give instructions in the school, and befitting premises, worthy of the school of sylviculture was found first in the ancient palace-castle of Villaviciosa d'Odon, a chaste and beautiful building erected in times anterior to the commune of Castile, destroyed partially on that account in 1520 , and restored internally in the year 158t, according to plans by the celebrated Juan de Herrera, honoured of Spain, and the creator of many of her architectural treasures.

By a Royal decree of 18 th August, 1847 , the regulations were confirmed, and the school was opened on the 2 nd of January, 1848, under the director and four professors, with a vice-director and assistant professor superadded. All af these are spoken of in terms of high commendation.

Villaviciosa was situated, as has been stated, some four leagues and a-half from Madrid. Senor Castel writes:-

'If we advert to what has been said elsewhere in regard to the conditions of the place where the school was to be located, it may be remembered that according to the arrangements laid down in 1835 and 1843 , it was required that the school was to be created in the Capital. "ihe Royal decree of 18 th November, 1846, is the tirst public document from which it appears to have been determined that the school of forestry should be established in some lacality near to this-and in consequence-though the statement is but vague-away from Mladrid, the centre of superior instruction in all Government civil career's, ant in many of the military ones. It may be asked-what was it which determined this resolution, which was maintained in the Royal decree of 1847 , and to which practical effect was given in appropriating for the purpose the palacecastle of Villaviciosa, in which the classes were opened on the 2nd January: 1848 ?

'Two principal arguments which suggest themselves at once as fundamental ones which may have weighed with the Government are these: The beliet that a school of sylviculture would find its natural and appropriate place in the 
midst of fields, and near to a forest where the practical application of the fundamental studies might be possible and easy; and the knowledge that there did not exist in the city a property with suitable buildings: this might make the acceptance of the offer of that building more easy for the founder than to take from the general funds an amount, necessarily large, for the construction and fitting up of premises destined for an establishment which in truth owcd its birth more to the personal energy of one resolute person than to any spontaneous and creative interest taken in it by individuals occupying a prominent place in the administrative centres concerned.' And he proceeds:-

- We may here glance for a moment at the primary prerequisites of such an institution, and at the measure in which the castle of Villaviciosa met these, as these had led to the preference being first given to Madrid by Professor Don Maximo Laguna in 1866, and supported in his remarkable menoir, Éxcurcion Forestal por los Imperios de Austria y liussa , he considering that from the particular character of the fields around Villaviciosa and, the insignificant population there, with the absence of all scientific appliances beyond those pertaining to the school itself, that place could not compete with Madricl as a site for a school of forest eugineers, the slight advantage gained by facilities for practical instruction being eclipsed by the immensely greater facilities for scientific instruction presented by the numerous nuseums and libraries which enich the capital of the kingilom.

'More weighty however, and determining, in my opinion, the uiterior decision, was the circumstance that within three leagnes and a-half from the city was a magniticent palace, which cuuld be had by the State at comparatively small expense, and on which necessiry works of repair and adaptation conld be executed at inuch less expense than the rents yielded by it-au immense benefit not easily to he met with elsewhere. And there the school was estabished in 1847, at least temporarily, as said Senor 
Laguna, the most weighty reason being that it was now a question of-'To be or not to be. Before that question all the considerations which have been mentioned, and all others which might have been advanced, had to give way; nor could this be considered in any way a censure on the honoured founder, as the aforementioned Forest Engineer clsewhere remarks: "Bitter vexations always accompany him who initiates or attempts to carry out an improvement; and the noble patrician, together with all the worthy persons who with disinterested patriotisn liave contributed to open the gates of the castle of Odon to the studious youth, deserve for ever the applause and gratitude of those who have any regard for the truc advancement of the country."

Much is attributed to the zeal, energy, intelligence, and influence of the director, Senor Don Bernardo de lia Turre Rojas, of whom mention has already been made, and to the practical experience and knowledge of moderu forest seience of Professor Don Agustin Pascual; and elévé of the Forst-Austalt, of Tharand.

The course of instruction soon became considerably developed and extended. Mucb was done by virtue of inherent energy, and powers given to the senatus and staff of professors. As extended powers were required, these were given or sanctioned by successive Royal orders. Besides those which have been referred to, there are inentioned by Senor Castel a Royal order of 2d July, 1848 ; one of 24 th November, 1849 ; and one of 29 th November of the same year; one of 18th January, 1850, and of 4 th April of that year. By these alterations, aduitions and corrections were made in the regulations which were originally issued. And again, additions were made to the studies prescribed, ard modifications in the arrangements for the prosecution of these, by a Royal ordinance issued 31st January, 1858.

Additional and greater changes were introduced by a Royal decree of 20 th September, 1858, which greatly 
modified the programme of study. On the 31 st Octuber in the following year (1859), arrangements were made for the establishment of a school of practical forestry, in which instruetion might be given in furest work uuder the direction of a forest engincer ; and these were curried unt in the institution of such a school by Royal urder of the 9th December of that year, in the forcst of Espiuar, a village in the Province of Segovia

About the same time, in consequence of the flourishing condition of the School of Forestry at Villaviciosa, a scheme was formed for raising still higher the character of that school by increasing the number of sciences in which instruction should be given there to candidates for appuintments as forest engineers, su as to make it equal to other special schools of the highest estimation in the countryif not also to the most distinguished schools of forestry in other lands. This was carried into effect in accordance with a Royal decree of 18 th May, 1862; and at the same time the school of practical forestry at Espinar was given up, after a year's experience, under the direction of the Forest Engineer-in-Chief in charge of the service in the Province.

In no other respect was the course of study greatly changed, but this has been considered as marking the close of the first, and the commencement of the second stage in the development of the school.

In that first stage of this development very great inportance was attached, and not improperly, to training in practical work in the forests. In the second stage now commenced, without detriment to such practical work, more atteution than had previously been given was given to education, and instruction, and study, during the school session, and practical training was prosecuted away from the school in forest districts; and at this time the several museums attached to the school received great additions : they then eutered upon that development which has secured for them the full equipment which they have now attained 
by additions obtained on the occasional and annual excursions of the students, and otherwise.

A campo forestal, created in 1850 in connection with a leafy wood of elms in the immediate vicinity of the school, which, with some adjacent ground, was planted with pines and beeches, and served for the practice of students in sylviculture, and the acclimisation of trees from other countries, now took more and more the form of an arboretum, or jardine forestal.

In the spring and autumn, to supply lack of practice in forest work, excursions were made sometimes to the piueries of the Sierra del Guadarrama; at other times to the oak and beech woods of the Liebana; also to the pineries of Cocat to study the collecting and manipulation of rosin; and to the magnificent forests of Valsain and the Espinar, and to those which form the great mass of the Serranias of Cnenca and of Segura, in the province of Jaen. In these excursions the students were accompanied by some one of the professors, who, to quote from Senor Castel, 'in one place finds what suggests the explanation and discussion of matters pertaining to botanical geography, in another records of geognostic and mineralugical knowledge already acquired in the school, and always spots suitable for exercising the students in fixing forest cornpartments, in determining the ages of different kinds of trees, in calculating the pussible yield of produce, and the many other problems which go to complete the questions embraced in the systematic arrangement of a forest.'

In the year 1866 there was published by Royal order, a report of a Tour of Observation of Furestry in the Empires of Austria and Russia, made by Royal order in the spring of 1864 by Sr. D. Maxima Laguna y Villanueva, Forest Eugineer-in-Chief of the 2nd class, and Professor in the School of Forestry, Excursion Forestal, \&c., to which reference has already been made. In this there is given the Royal order, communicated by the Minister de Fomento, under date of 30th May, 1864, requiring Senor 
Lagurra to undertake the tour of observation in question, and give his attention to the state of information and mode of instruction, the administration of the forests, anl] the cultivation and improvement of the Steppes in the Empires of Austria and Russia.

The report treats also of the instruction given in Austria in the schools and academies of Mariabrunn, Schmnitz, Weiswasser, Ausee, and Krenz, comparing it with that given at Villaviciosa, and proposing certain useful modifications in this. It then discusses the forest services of Austria and Bohemia, Hungary and Saxony, together with the instructions in forestry given in Russia, in the School of Practical Forestry in Lissino, and in those of the Steppes, and the general administration of forests in Russia.

From 1862, the programme of study then instituted, with such modifications as have been iudicated, was followed for six years. But by Royal order of 22 nd July, 1868 , approval was given to a new programme of entrance examination to the so-called special schools of the kingdom; and on the 2:3rd October of that year there was issued a decree reorganising the special schools of roads, canals and bridges, of mines and of forests. By this the number of studies required in each school was reduced, and there was substituted for instruction in these in elementary and higher mathematics, and a good many of the physical science, entrance examinations on these subjects; and on 24th October, 1870, there was issued the regulation completing what was then begun. The reformation ultimately effected, which arose out of the Acts of 2:3rd October, 1868, and of 24th Octoler, 1870, is what is now in operation, modified only in one or two points by Royal order of 25th May, 1877. By the decree of -3rd October, 1868 , the prescribed course embraced a period of three years; by the decree issued luder date of 24 th October, 1870 , it was so extended as to embrace a period of four years; but by a temporary or provisional arrangement it is at present compleied in three year's. 
The first year embraces the study of topography, geology, cubic mensuration, and applied mathematics; the second year-chemistry, mineralogy, botany, zoology, and geology; the third year-construction, sylviculture, forest economy, political economy, and administrative law; and of late years a private preparatory school for students has been organised and conducted.

Students on leaving the school are attached, in the character of candidates, to forest districts ; and it is only after passing through this stage of training that they receive appointments as Forest Engineers of the second class.

By His Excellency Senor Don Bernardo de la Torre Rojas, founder of the school of Forest Engineers of Villaviciosa de Odon, there was published in January, 1880, an autobiographical pamphlet entitled Ingeniéros de Montes-Recuerdos de la Fundacion, in the concluding note of which the author expresses bis desire that it should be considered as part of his last will and testament recommending the treatise to the Forest Engineers that they should see to the preservation of it, as a family memoir, and as the last evidence he could give to them of his unchanging affection.

In the treatise itself, is declared, the philosophical sentiment adopted by him, and embodied in the institution to the effect that productive work must be founded on knowledge saber es haser, el que no hace unsabo. He traces cursorally the history of the creation of the school, states certain ruling principles which served as a guide to him in what he did in founding it, and in giving to it the practical character impressed upon it; he comments on these, and enlarges ou the bearing of them ou the creation and maintenance of an esprit de corps, and the importance of this, together with self-negation, of high moral character and conduct, of discipline, and of other fundamental requirements in every professional institution designed for the service of the state. 
A third stage in the development of the school commenced with the removal of it from Villaviciosa to the Escurial. Of this change Senor Castel writes:-

- At no great distance from the Court, and in this respect not otherwise than in accordance with the text of the decree of 18 th November, 1846, there was in possession of the State a valuable jewel, the bequest of the piety of our kings, and a superb manifestation of the genius of our artists. In this, among its numerous adjuncts, there were buildings abundantly spacious, and in conditions equally adequate to lodge worthily a school, though it should have to come thither from an ancient palace, the property then of the Counts of Chinchon.

'The first building of the adjuncts to the palace, one erected for the lodgment of attendants on the Royal Court, was the building appropriated in 1869 , with necessary alterations, as a site for the school which still occupies it.

'It may be asked what were the considerations determining this arrangement? On the one hand there was the desire to save the money, which, under the head of rent for the palace school and the experiment ground, hacl annually to be paid to the proprietors; and, on the other, aII 11 rent neressity existing for enlargerl accommodation for the muselums and cabinets, for more numerous and more viluable oljects counected with the instruction given, which had been presented to the institution, than conld he procured in the buildings originally assigned to them; and in fine the appropriate forestral situation of the Royal palace of San Lorenzo, and the facility which existerl there for enriching the school with an experimental forest, a garlen in which culture might be tried, and spacious gromuls tor the varions forms of practice which the instruction of the students might render desirable. Without inaterially exceeding the distance from Madrid, and virtually diminishing this by the superior facility of communication, the new site prepared for the school fulfilled two important conditions: it gave to the school a spacions 
building adequate to its requirements, and it offered to the school certain facilities for the praetieal study of science, in which respect the town of the Escurial compared advantageously with that of Villavieiosa, which were inereased by the greater facility for communicating with Madrid. To such an extent was this the case that amongst the opinions expressed by parties best qualified to form a judgment in regard to the expediency of the remoral of the school from the one place to the other, there appears an approval expressed by the founder of the School of Forestry, His Excellency Senor D. Bernardo de la Torre Rojas, who, after the removal, visiting what he always ealled his dear school, declared with the utmost cordiality the satisfaction which he felt in seeing it located in a situation more appropriate to the requirements of the institution.

"The alterations, rapidly executed with remarkable skill under the direction of Professor Don Ignatio Maeias allowed of the iransference of the sehool during the vacation at the end of 1870 , and the eonsequent opening of the classes in the new premises on the 7 th of January, 1871, and thus, in so much that it coincided with the decree of the 24th October in the preceding year, may be said to have completed the second period, and commenced the eurrent period of instruction in this school.'

In the transferred school the previously existing regulations continued in force for years, being only modified by some slight alteration in the entrances and examinations made by Ruyal order of 2.5 th $\mathbf{J a y}, 1877$; and while it had been the case that there were two classes of students, one resident within the school desiguated Interior, the other being outside designated Exterior, but in every other respect enjoying the same advantages, privileges, an 1 status, - this was altered, and only one class was now rocognised the Interior, though, in consequence of the removal of the school to the Escurial, while the designation was retaiuend all the students lived outside the school. 


\section{CHAPTER III.}

\section{THE SCHOOL OF FORESTRY IN THE ESCURIAL.}

IN the School of Forestry in the Escurial, as was the case in the School of Forestry at Villaviciosa, for some years previous to the removal of the school to the Escurial, the curriculum of study embraces two periorls-that of preparatory studies; and that of what are more strictly reckoned professional studies.

The so-called preparatory studies are classified, and are arranged in two sections, the first of which may be attesterl by academic certificate; the second comprises matters on which the aspirant must pass an examination at the School of Forestry. The former comprises Spanish grammar, latin grammar, geography, and general history, with special knowledge of the history of Spain. The latter comprises arithmetic, elementary, and the higher algebra, plane and solid geometry, rectilinial and spherical trigonometry, analytical geometry of two or three dimensions, natural philosophy, chemistry, natural history, lineal, topographic, and landscape drawing, French and German.

'The second period of study embraces four years spent in the school. The studies pursued during the first of these years comprise topography, integral and differential calculıs, applied mathematics, applied cheinistry, and drawing.

The studies of the second year comprise theoretic and applied mechanics, geology, meteorology and climatology, construction, including luilding and hydraulic engineering, and drawing.

In the third year are studied mineralogy and applied geology, applied zoology, applied botany, sylviculture, and drawing.

In the fourth year silometry, or measurements of wool 
of every kind ; forest ordenacion, or partition and exploitation on scientific principles ; forest industries ; the administration of law; political economy ; and drawing.

This summary, however, can convey to one unacquainted with the programmes of studies followed at such schools a very inadequate conception of what is comprised under the heads stated as has been intimated.

In order to gain admittance to the school, the applicaut must be accredited by certificates or diplomas of having passed an academic examination in the following subjects - Spanish grammar, Latin grammar, geography, and the general and detailed history of Spain; and he is admitter, after passing with approval, an examination in the school on the elements of natural history, the elements of the theory of mechanics, descriptive geometry and its application to projections and to perspective, physics, chemistry, lineal, topographical, and landscape arawing, and his knowledge of the French and German languages.

The attainments made in the latter preparatory studies are determined by personal examination at the school. Every year there are issued programmes specifying the subjects on which applicants for admission must be prepared to be examined. According to the progranıme for the year 1877 , the only one I happen to have at command, the preliminary entrance examination through which applicants have to pass embrace amongst others the following subjects: - Theory of mechanics, the general principles of statics, and their application to the determination of the centre of gravity; the general principles of dynamics, including inertia, momentum, reaction, vital force, movements of points and movements of bodies under varied conditions, and the establishment of equilibrium. Descriptive geometry: its application to projections and perspective, embracing points, straight lines, circles, and planes, triangles, polyhedrons, sections and intersections of these, tangents, cylinders, cones, lines of revolution, involution, plane and conic sections, the projection of 
shrdows, and the geometrical laws of perspective. Physic: : properties of bodies, gravity, specific gravity peculiarities of solids, of liquids, capillarity, gases, atmospheric pressure, elastic force of bodies, flotation, and temperature. Acoustics : propagation of sound, and distinctive character of sounds. Heat: expansion of bodies in a solid, a liquid, and a gaseous state, and operations by which it is effected; hygrometry: and transmission of heat. Optics: propagation of light, pbotometry, reflection from plane and curved surfaces, refraction and dispersion of rays, structure of the eye, optical instruments, double refraction, and polarization of light. Electricity and magnetism: static electricity, distribution by conductors, measure of electric force, magnetism, dynamic electricity, electro-magnetism, electrotelegraphy, thermo-electric currents, electric induction. Meteorology : thermonetrical observations, winds, aqueous phenomena, electric phenomena, luminous phenomena. Chemistry: chemical notation, combining proportions, theory of chemical equivalents, specific heat, atomic theory, metalloids, and their nore important compounds, other elementary bodies, the more important coinbinations of hydrogen, combinations of oxygen with other quasielements, fluorate of silica, carburetted hydrogen, cyanogen, general properties of metallic and other salts, special study of the more important metals and their compounds. Natural history: distribution of existing bodies in groups and kingdoms, distinctive characteristics of species, of organs, apparatus and functions, mode of studying minerals and determining their production, composition, and importance, crystallography; classification, nomenclature, and chemical properties of minerals. Botany : structure and forms of vegetables, organs of vegetation, roots, stems, leaves, with their variation and arrangement, and effect.s of this on ramification ; flowers, inflorescence, calyx, corolla, stamens, pistils, and ovary ; fruits, seels, vegetable physiology, nourishment and growth, reproluction, classification, and specification of properties common to classes of plants. 7oology: difference between animals and vegetables, 
animal structure, organography, and physiology ; classification proposed by Cuvier and modified by Milne Edwards; characteristics of mammiferæ, with description of the principal families of rodents, of pachydermata, and of ruminants; characteristics of birds, and description of the principal families of gallinaceons, of wading and of wehfooted birds; characteristics of fishes, and description of the principal families of soft-finned fishes; characteristics of the principal families and the more remarkable genera of the coleoptera, of the orthoptera, hymenoptera, and lepidoptera; and the geographical distribution of animals, with causes influencing this.

On such subjects the candidate for admission is examined before he can enter the school. He is free to pass through these preliminary studies when and where he pleases; and there are specified works on the several subjects from which information preparatory to examination may be obtained.

It is stated that in the examination in drawing there will be required manifest facility in copying correctly an order of architecture, or a machine; some model drawing of a landscape in Les Etuds d'aprés N'ature, by Calamé, and a pen-and-ink representation of mountains, sands, rocks, and arable land, according to the method of Rindavets; and in French and German, correct translations from these languages into Spanish.

Application for admission must he made previonsly to the 1 st of September in any year.

It is not requisite that the applicant should be examined in any one year on all of the subjects embraced in the entrance examination, and he is required to specify those on which he desires to be examined. If he pass any examination with approval, this will be certified, anı when he has been examined in all with approval he will be admitted, and enter on the special studies of the school.

After admission the first year's course of study, as has 
been stated, comprises among other subjects, topography, applied mathematics, and applied chemistry.

The programme of studies under the head of Topography comprises 1 . The determination of the object of topography and the difference between this and Geodesy. 2. General rules in regard to triangulation, and methods of giving a graphic representation of the ground. 3. The selection of a system which should be followed, and methods which should be employed according to the cases in the preparation of a chart or plan; and methods to be adopted in the case of lands covered with woods. 4. A theoretic and practical knowledge of the instruments and apparatus employed to obtain the data required; and of instruments more adequate to meet the necessities of forestral topography. 5. Calculations to be made with the data obtained. 6 . The constructions of plans; horizontal projections; and scales. 7. The resolution of partial problems, such as tracing lines of the same altitude or level; valuation or determination of areas and volumes: the division of superficies, and the finding or training of proper divisions in the forests, in order to the separation of quarters, sections of the forest for successive operations, and limits of fellings.

With regard to Applied Chemistry, it may be remarked that amongst the preparatory studies, a satisfactory knowledge of which is required as a preliminary to admission into the School of Forestry is the general science of chemistry. In the school studies, under the head of applied chemistry, is comprised the study of the objects and the rivisions of analitic chemistry, mcluding: 1 . With regard to a laboratory, the instruments and apparatus which it should contain, and the use and manipulation of these. 2. Reactions and general chemical analysis. 3. Quantative analysis, and the volumetric methoil of procedure. 4 . Qualitive and quantitive analysis oi rocks. 5. Analysis of earths in general, and in particular that of those which constitute the soli of the forests. 6. Different methods of 
reducing plants to ashes, with a special regard to that of liguous plants, and the qualitive and quantitive determination of the fixed elements in the same. 7. General analysis of the waters and the elemental constituents of organic sulustances. 8. Application of chemistry to vegetable physiology and to sylviculture, to the preservation of woul, and to the carbonization of wood, and the determination of its caloritic poteney. 9. Dosification or determination of quantity of tannin in materials containing this.

In the cabinet and laboratory of chemistry provided for the instruction of the students in chemistry, there is in the school an extensive and well-equipped laboratury, with various furnaces, water-pipes, and four tables covered with zinc. Crucibles, capsules, retorts, mortars, retort stands, lamps of different kinds, and other accessory utensils are there in no stinted numbers; and pneumatic troughs, water and mercurial glass jars of different sizes, permit of the collecting and study of gases.

A varied collection of reactives to facilitate analytical experiments are contained in a case of great value, together with the more indispensible apparatus, which, in virtue of its small volume, is contained in the chest of Platner, made with admirable perfection.

Amongst other articles and apparatus deserving of special notice may be mentioned eudiometers of Volta and of Hitscherlich; different delicate balances; the apparatus of Donovan for filtration without access of air; that of Marguerite for the dosification of oxygen; that of Guy-Lussac for the analysis of potash ; that of Pelouce for the analysis of copper ; that of Mohr for the extraction of cther; the sulphi-hydrometer of Dupasquier; the saccahrometer of Mitscherlich; the apparatus of Bunsen and Bischoff for spectral analysis; and various others not less important for the aualysis of earths, of chlorine, of lead, and of other bodies.

Amongst the material pertaiuing to analytical chemistry the school possesses the elements necessary for volumetric 
analysis, by means of specified liquids and for the qualitative and quantitative analysis of organic substances.

In the studies of the sccond year arc comprised those of applied mechanics; geodesy or land surveying ; meteorology and climatology and construction, under which are comuprised works of hydraulic engineering and furest buildings.

The programme of study in Applied Mechanics comprises: -1 . The general ideas and principles and genera! laws of forces and mution. 2. General ouservations on inachines, and the study of their essential organs. :3. Chauges of motion of most frequent application in unachines, moderaturs an 1 regulators, passive resistances. 4. Transport in general ; forestal transports. j. General priuciples of hydrology water gauge of natural aud artiticial currents; the distribution of waters; modules or appliances for securiug uniformity of delivery; and partidors for securing the same in dividing currents; units of measurement in the gauging of waters. 6. Calculation of resistances, thickness of dykes of conducting pipes and of steam boilers. 7. Motors: hydraulic motors, steam motors, wind motors. S. Machines employed for raising liquids, machines employed to transmit gases. 9. Forestal tools and instrumeuts : hammers, machines, mills, cutting tools, and saws.

In the Cabinet of Mechanics there are various levers and balances; pulleys, single and convined, and in blocks; models of simple and differential wheels, and wheels with a catch ; capstans ; cylindrical and conical accumulators; cog-wheels; elevator; fixed crane, and moveable crane; inclined plane, wedge, shears, circular eccentric ; expandiug eccentric; spiral of transformation; vertical and circular saw ; Atwood's and Morin's machines; apparatus to demonstrate the parabolical movement in the fall of solids and liquids; pendulums, simple \& Kater's; endósmo. meter of Ducrochet; Vènturi's apparatus; apparatus of 
capillary tulues, that of Bolnnénberger ; syphons, ordinary double syphon, and that of Porta; float of De Prony; funnels, gasometer, spherical float, hydrometric pendule, tube of Pilot, rheometers of flat paddles, and of Polellu; Wolturau's mill; different parts of pumps; pistons and valves of different kinds; suction pumps, forcing pumps, suction and forcing, aud combiued rotary pumps of different kinds; water-wheels with cords, and with chain pumps and buckets; archimedian screw ; drum ; hydraulic ram ; water-wheels with flat floats, with boxes, with buckets, and that of Poucelet; turbines of Fournevion, and of Koechlin; wicd mills; distributors fixed, and oscilating cylindrical ; Leroy's spring' dynamometer; steam engrines, differeut models; Krampton's locomotive.

The programme of study, under the head of Geodesy, comprises :-1. The determination of the object of geodesy or land surveying. 2. The necessity of a network it triangles, in order to the determination of the distauce of given points un the ground, and the projection of these on the area of the ground. 3. Stations and signals; a general idea of the superficial figure of the ground; geographical maps; a knowledge of the geodesic iustruments required in the calculations of the angles of the triangles, different modes of procedure, and causes of error which it is necessary to avoid or to correct in each case. 4. A basc line and apparatus for the measurement of it; the connection of this, the base, with the triangles of the network, and calculation of the sides of each triangle. $j$. Determination of the longitudes and latitudes of the vertices and azimuths of the sides of the triangles, and the distance of the meridian and its perpendicular. 6 . Geodesic determination of altitudes; and barometric levelling, or determination of altitude by barometric observation. 7 . Necessity of triangulations of the second order; difference between this and the first in respect to operations and calculations; convenience of triangulation ut the third order, in order that a connection may thus be 
obtained between the operations of geodesy and thuse of topography. 8. Construction of geographic maps.

For instruction in topography and geodesy, and for use in practical exercises in loth departments, the schuol contains, writes Signor Castel, abuudant material, acquired for the greater part with funds supplied by the State: Grouping the articles with a view to a brief description of them, they may be classed together in the following order :-

Apparatus for use in the divect measurements of distance.Chains, tape ineasures, similar measures made of elastic steel, levels, and graduated rulers.

Apparatus for , ase in the indirect measurement of distances.A Lugeol micrometer, Ertel's telemeter, longimeter, eycglasses of the tacheometer, and of the olometric theodolite of Porro; mobile estadias; Groetar's apparatus.

Angle-determining instruments. -Quadrants, pantometers, graforneters, box compass, Burnier's compass, level with vertical are, Ladois' level, Linglaé's level; sight, with reflection by Porro; Kater's compass, Cugnot's planchette or cireumferenter, French planchette, German planchette of Lehman, planchette perfeeted by Ertel and Starke; quadrant with sights, with eye-glass, with eye-glass and level, with an are of a circle; declinator used in dialling, copper compass, reflecting mirror, quadrant with two eyeglasses; graphic sextant, another with two eye-glasses, pocket sextant; Porro's sextant, refleeting by prisms with water-level; the same, with sights and one eye-glass; Porro's octant of reflection and graphic prism; Douglas's circle of reflection; artificial horizon; theodolites on system of Richer, Spanish theodolite, German theodolite of Breithaupt, theodolites of Troughton, Pastorelly, Evererest; Troughton's repeater; Brunner's theolodite of the third order, Brunner's of the second order; Troughton's great zeni-azimutal circle; Gaus's heliotrope.

Instrumunts used in levelling.-Mason's level, water level, level with prism and perpendicular, clisimetres of Burel and of Mayer, levels of Chairgrasse, levels with sights, 
level of mercury and eyeglass, Porro's simple level, Porro's level with compass, simple level with eye-glass, levels of Ertel, of Grairats, of Casella, and of Lincke with eye.glass, eclimetric level of Chezy, great level of Dollon; miras, or sight knobs of different kinds.

Instruments used in constructing Plans.-Case of large mathematical instruments; pocket case of instruments; graduated scales of wood, white metal, and platinum; rulers and squares, gruduated squires, compasses; semicircular transportador, with scale; another with scale and nonius, one with entire circle and nonius, that of Trongton with two nonii ; pantograph.

Determination of areas.-Planineters of Elliot, and of Beuviere and Starcke.

l'arious instruments.-Eye-glass of prism, nt Porro, if whervation and delineation; astronomic telescope, spherometer, Focometer,chronometer,D. Carlos Ibannez's apparatus for measuring hases; rule, stands, microscopes, levels, eycglass for delineation, eye-glass for references, tracer, \&e.

The programme of study in meteorology and climatology inmprises-1. The sturly of the atmosphere, and its principle properties. 2. The nature and laws of light, heat, magnetism, and electricity, and phenomena presented by each of these agents. 3. Winds: their origin, laws, and different characters which they present. 4 . Aqueous meteors, and theories and hypotheses advanced in explana. tion of them. 5. Theoretic and experimental study of apparatus used to measure the intensity of meteorological ptsenomena. 6. Connection and dependence of some meteors on others. 7. Climates : facturs which determme the origin and classification of different climates. \&. Action of the atmospheric agents and of meteclological phenumena on the life of plants. 9. Relations betiveen the factors of climate and the orography, nature, and vegetation of an exteusive district.

The Cabinet of Meteorological apparatus and a Meterrological observatory contain an anemometer by M. Osler; 
and another, that of Dr Robinson; a Larometer of Newman, a large specimen; a well barometer, of the English pattern, with the scale in inches; two of Fortin's barometers; a barometer of Gay-Lussac; an aneroid barometer; a barometer of M. Bourdon ; a hygrometer of Regnault, a hygrometer of Daniel; an English psycrometer, by M. Casella, on Masson's system; ordinary thermometers; also maxima and minima thermometers; also that of Walferdin, \&c.; and a pluviometer.

Of the arrangements made at the Escuria to facilitate the study of forest science, that which proved nost interesting to me was the observatory, partly because of the importance of the oljects which it was designed to subserve, partly because of the know?edge I have of work done by students in the prosecution of researches connected with them after they have left the school; and partly because of the simplicity and inexpensive character of the arrangements made.

The meteorological observatory is in the campo forestale of the school. It is a building of less than twenty feet square, and of similar height. On the flat stone roof of it are arranged the instruments employed. To them all the students have access at any time. Of these, from time tr time, two are appointerl to make and record observations.

The observations made by the students are published every fortnight in the Revista de Montes, in a tabulated inrm. In this are stated in regard to every day the height of the barometer at 9 ...M. and at : P.M, the average or medinm height of these, and the variation found by substracting from the greatest height at 3 P.M. the Inwest at ? 1.M.; the maxinum and minimum temperature; the variation and the modium temperature of the ground; the relative humidity at the same hours; the rainfall; the direction and the force of the wind; and observations in regard to the clourls in ennnection with the state of the winds.

The studies comprised under the head of Constructions 
are-1. The general conditions of a good construction, and the materials enployed, including an examination of the qualities, extraction, preparation, and fabrication of these materials. 2. Foundations, and operations relative to the establishment of these in different cases; sinking wells; raising piers. 3. Construction of walls, partitions, and roors. 4. Stables, sheds, bridges. 5. Hydraulic works: tracing and locating confining walls and dykes; arrangement and construction of leading canals, and of canals of derivation. 6. Application of principles of construction to seed-drying stores, and stores of timber and tirewood, pitch kilns, and saw-pits or saw-mills. 7. Road-making: highways, for est wood tracks, and forest bridges.

In the studies of the third year are comprisedMineralogy and Applied Geolingy, Applierl Botany, Applied Zoology, and Sylviculture.

The programme of study in Applied Geolngy comprines -1 . Definitions and divisions of geology, and specifications of its relations to the other sciences, and especially to sylviculture. $\because$. General geography, which treats of mountains, and in particular the geograply of Spain. 8. Physical gengraphy. t. Petrography, or natural history of rocks aud stones; origin of rucks, their characteristies and analytical decomposition. .. Natural decomposition if rocks, natmre and forestal conditions of the lawd this ponduced. 6. Ceologic periods, natural history of stratiiiation. 7. Description of the different geognostic formations which constitute the terrestrial crust, and their forestal applications. \$. General notions of palæontology, and description of the principal fossils characteristic of each formation.

Instruction in what is desiguated Applied Mineralogy comprises-1. Fundamental irleas, and the characters and chemical and physical properties of minerals. ‥ Chrystalography, systematic mineralogy, different classifications of minerals. :3. Analysis of minerals. 4. Description of the more important kinds of minerals, with special attention 
given to those which enter into the composition of the rocks and the soil found in forests.

For use in the study of geologic mineralogy the school possesses two collections : one chrystalographic, the other mineralogical.

The chrystalographic collection is composed of 336 models in plaster of Paris, formed and arranged aceording to the system of Naumann, and containing in each chrystaline system representatives of its typical holoédric and hemiédric forms, and of the more remarkable combinations of one form with another, \&c.

Double erystals, or hemitropes and anomolous and imperfect forms : there are in this collection crystals and models representative of the fundamental forms of the recognised systems of these, and of their primary derivation.

The mineralogical collection contains 770 specimens, each of which is representative of a type, a variety, or a different locality. It comprises 175 distinct species, amongst which are representatives of the 15 classes of Naumann, on whose system they are arranged; there being largely represented the classes -1 , metallic oxides; 3 , haloids; 5, geolites; and 6 , anfoterolites: these heing considered the most important for study in the career of a forest engineer.

And for instruction in geology this museum contains, as important auxiliaries, a petrographic, and also a palæontological collection.

The former is composed of 800 specimens of rock, of which the greater number are Spanish, and some are French, representing the most varied types and varieties of the principal species found in the Peninsula.

The collection of fossils consists of 1200 rpecimens, classified according to different characters of gromud, after the method of d'Orbigny, and hringing together types of the most characteristic species of all of these. The total number of species represented is abont a thousand. 
Under the head of Applied Botany, or botany in its connection with the studies and subsequent work of the forester, there are included in the prescribed programme of the class -1 . Definitions and general ideas in regard to organised bodies. 2. Characteristics of plants or vegetables, organography and morphology. 3. Anatomy, physiology, and nosology of plants. 4. Methodology, classitication in general, artificial systems of classification. j. Natural classification 6. General description of the principal families of plants, with a special and detailed description of the roody plants of the flora of Spain. 7 . Geographical botanical association of vegetables, affinities and analogies determining their distribution. 8. Agents influencing the distribution of plants. 9. Distribution of trees and shrubs in the forests of Spain.

In the Cabinet of Botany, in the museum, there were coutained, according to Senor Castel in 1877, the herbarium of the Senores Boutelou, presented to the school by Dona Maria Soldevilla de Boutelou, in the year 1848. In this herbarium there are 9244 species of plants from different countries, a great proportion of them being from America; another European herbarium of 3000 species, the greater part of them being French, but the collection being increased from day to day, chiefly by the addition of Spanish plants ; and a herbarium of 500 species of Spanish lignous plants prepared by the 'Comision de la Flora Foresta' ; ${ }^{*}$ a herbarium composed of plants found in the vicinity of the Escurial, in which are more than 800 species of phanerogans; a collection of 120 species of ferns from the Phillipines, presented by the Ilmo Senor D. Isidro Sainz de Baranda; various collections prepared by Professor Rabenhorst, comprising in all .5030 species of cryptogams, distributed into the following groups: rascular

Amongst works illustrative of the natural history of forest trees and other plants, a nromineut place must be assigned to the works prepared by the 'Comision de la Flora Foresta,' by which was presented to the muscum of the school this herbarium of 500 suecies of lignous plants. Of this, deseriptive of the collection of specinens, and of sinilar worhs from the Phillippines, a n account will afterwards be given. These are made mention of here as supplyiug facilitics for the study of the speciments exhibited. 
cryptogams, 120 ; 111osses, 1200 ; liverworts, 550 ; lichens, 900 ; algae, 2260 ; a collection of transverse sections for the anatomical study of wood of differeut trees, presented by Professor Nordlinger, consisting of 500 species belonging t,o different regions of the globe; a microscope by Oberhamser, with two lenses.

The collection I funud considerably enlarged beyond what it was at the time Signor Castel prepared this ircount of it; but I did not enquire to what extent the specimens preserved in it had been increased in number.

Besides this museum, there are within reach, and of easy access, the trees growing in the botanic garden in Madrid, and those growing in the gardeus attached to the institufion at the Escurial.

In 1877 , the latest year in regard to which I have at cummand any reports, there were growing in the gardens attached to the school specimens of the following trees:-

Abies balsamea. Mill, Abies excelsa. D. C., Abies Norinda. R., Alies Nordmanniana. Spach., Abies pectinata. D. C., Ábies pinsapo. Boiss., Acer monspessulanum. L., Esculus hippocastanum. L., Androsœmum officinale. All., Aratcaria imbricata. Pav., Arbutus nuedo. L., Arbutus uva-ursi. L, Aucuba japonica. L., Berberis vulgaris. L., Bupleumun truticosum. L.. Buxus balearica. Lam., Buxus s.mpervireus. L, Buxus sempervirens, var. aurea. L., Castanea vesca. Gaertn., Catalpa bignonioides. Walt., Cedrus atlantici. Manett., Cedrus Deodara. Loud., Cedrus l,iliani. Barrel., Celtis australis. L., Cephalotaxus peduncul:ans. Sieb.: Cerasus Lauro-Cerasus. Lois., Cerasus lusitanica. Mill., Cercis siliquastrum. L., Cissus quinquefolia Desf., Cistas salvixfolius. I.. Clematis vitalba. L., Cornus san"gıiner. L., Coronilla glauca. L., Cratægus monogyna, Jacq., 1 inpresus fastigiata. D.C., Cupresus glanca. Lamk., Cupresus In mizintalis. Mill., Cupresus pendula. Staunt., Cydonia japmniea. Pers., Cytissus Laburnum. L., Deutzia creuata. -irh. Dentzia gracilis. Zucc-Erica scoparia., L., Eriobutrra japonica Lindl., Fucalyptus globulus. Labill.,

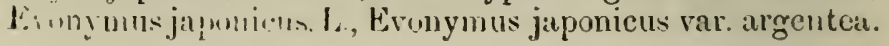


L., Evon ymus japonicus var. aurea. L, Forsythia viridissima. Lindi., Frangula vulgaris. Reichb., Genista florina. L., Gyneriun argenteum. Nees., Hibiscus siriacus. L., Ilex aquifolium. L., Jasminum fruticans. L., Jasmin. nudifloruu. Lindl., Jasminum ofticinalc. L., Juglans regia. L., Juniperus oxycedrus. I., Juniperus virginiana. L., Lavandula spica. L., Ligustrum japonicum Thunb., Ligustrum vulgare. L., Ligustrum vulgare. L., Ligustrum fol. variegatis. L..

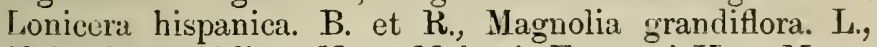
Mahonia requifolium. Nutt., Mahonia Fortunei. Hort., Morus alba. L., Myrtus communis. L., Nerium oleander. L. Paliurus australis. Gaertn., Paulownia imperialis. Sieb., Philadelphus coronarius. L., Phlomis fruticosa, L., Photinia. serrulata. Lindl., Pinus Austriaca. Tratt., Pinus halepensis. Mill, Piuus insignis Dougl., Pinus laricio. Poir., Pinus pinaster. Sol., Pinus pinea. I., Pinus pinea. var. fragilis. Lois., Pinus sabiniana. Dongl., Pinus Strobus. L., Pinus sylvestris, L., Pittesporum chinense. Don., Platanus vulgaris. Spach., Populus alba, L., Populus balsamifera, L., Populus canadensis. Mich., Punicagranatum. L., Punica granatum flore pleno. L., Quercus suber. L., Rhamnus Alaternus. L., Rhus thyphina. L., Robinia pseudo-acacia. L., Rosa bengalensis. Hort., Rosa centifolia. L., Rosa Damascena, Mill, Rosmarinus officinalis, L., Ruscus aculeatus. L., Salix babylonica. L., Sarothamnus purgans G et G., Sequoia gigantea. Endl., Spartium Junceum. L., Syringa persica. L., Syringa vulgaris. L., Thuja orientalis. L., Thuja gigantea. Doug., Ulmus campestris. L., Viburnum opulus. L, Viburnum tinus. L., Weigelia rosea. Lindl.

Besides these, there had been planted during the years 1871-1876, while it was in connection with the school park of the Casita de Arriba, in the vicinity of the Escurial, specimens of the following species of trees :-

Abies pectinata. D. C., Abies pinsapo. Boiss., Acer pseud oplatanus. L., Argania Sideroxylan. Roem. et Sch. Escul us hippocastanum. L., Castanea vesca. Gaertn., Celtis anstralis. L., Cupresus fastigiata. D. C., Cupr. glaueru. 
Launk., Cupr. hurizuntalis. Mill., Cytisus Laburumm. L., Eucaliptus glubulus. Jauill., Fagus sylvatica. J., Fraxinus uxyphy.lla. Biel., Gleditschia triacanthos, Juglans regia. L., Ininiperus oxycedrus. L., Paliurus australi. Gaertn., P. vanarieusis. Buch., P. laricio. Poir., P. pinaster Sol., Pinupincei. L., l'. sylvestris. Is, Robiuia pseudo-acacia. L., Wuercus ilcx. L., Q. robur. L.-V. pedunctulata., Q. robur. L.V. Sexilitiora, Q. suber. L., Q. toza. G, Thuya orientat is. L., Ulmus campestris. L.

In the capital, moreover, there is the valuable Botanic Garden, to which there is free access for all, and in where there are not only umbrageous walks, lined with trees labelled with thcir popular scientific names, but numerous trees so labelled growing freely in the enclosed spaces. It was removed from a situation on the road leading from the palace to the Prado to its present position, by desire of Carlos III., and it abounds in the products of foreign climes.

In the first year of the present century M. J. F. Bourgoing, who had been Minister Plenipotentiary from Erance to the Court of Madrid, wrote thus of the foundation of the present fame of this garden: 'At the commencement of his administration of the Judies Galvez earnestly recommended to all officers-civil, military, and ecclesiastical - within the whole circuit of the colonies, to transmit to Spain whatever appeared worthy of notice in the three kingdoms of nature. His directions were complied with, at least with respect to the vegetable kingdom. Scarcely a year elapses without announcing the arrival from the Spanish Indies of some new plants, which augment the collection of the metropolis, or at least the importation of seed, of roots, and slips, which they endeavour to raturalise in the Botanical Garden at Madrid. Young botanists, whom the Court maintain in Mexico, Peru, and elsewhere, transmit along with their consiguments a description of the plants immediately within their observation, and of the soil and atmosphere which appear most congenial with them, and of the culture 
they require. Conformably with these instructious the professurs of botany deposit the germs transmitted to them in the earth; and attended by their disciples they wateh with the most wistful solitude their different appearinces during growth, in order to compare the propurties of these exotic plants with the description that has been sent to them.'

Such are some of the prorisions made for the study of applied botany.

Mineralogy, geology; aud zoology, with much besides, are all included in the Natural History in which the aspiraut is examined before being admitted in to the sehool; but there the prosecution of the study of each is continued. Under the liead of Applied Zoology is comprised :-1. A statement of difference between the general zoology and that of zoology pertaining to the department of forests ; observations on the organography and physiology of animals; and on organic harmouies, arialogies, and homologies. 2 . The classification of animals and nomenclature adopted; general theory of classifications. 3. General study of the vertebrates, with a description of the indigenous species useful or damaging to the forests. 4. Forestal entomology ; the importance of the study of insects with an application to the department of forests; a description of all the species useful and detrimental to sylviculture; study of preventive and destructive measures employed against those which are detrimental. 5. Geographical zoology, giving an idea of the distribution in the Peninsula of those animals to which pertains a forestal interest.

For the study of Applied Zoolugy there are in the cabinet of zoulogy the following collections:-

A collection of forty-five species of mamifers, in which there are, or were in 1877, when Senor Castel prepured the statement, comprised ninety-two specimens, amongst which predominate the insectivora, carnivora, rodentia, pachydermata, and ruminantia, being the groups most inupor- 
tant in sylviculture, and amougst these are specimens of all the species found in the torests of Spain.

Another is composed of 103 species of birds, of which there are 141 specinieu; ; the most numerously represented being the raptores and the passeres. Another of 37 species of reptiles and bactrians, and some river fishes.

A collection of $16+1$ specimens of insects, distributed under 522 generi and 1000 species, comprising a great part of the foreign as "ell as indigenous species useful and hurftul to forests. 25 picture-frames contain woods attacked by insects; in each of these is a specimen of the wood, with the damage done, and the insects by which it is attacked.

A collection of nine anatomical frames represent in wax figures, on a large scale, the digestive apparatus of certain insects, the ovaries and spawn of the lobster, and the nervus system of the cephalopods, prepared by D. Jacinto Castro, the naturalist preparer of the school.

There are also two collections of shells, composed one of 102 species, and the other of 196 species, consisting of 400 specimens, the latter prepared by Senor D. Luis Urrejola, an engineer-in-chief of the corps. Besides these, there are sundry small collections for use by the professors and in the practical studies of the alumni.

The programme of Sylviculture studied in this the third year of the course, comprises:-1. The natural history, \&c., of different species of trees cultivated. :2. Extent of successive fellings, and duration of cycle or period embraced between sowing and clearing of successive crops; and metheds of explnitation: timber forests, coppice woods, and mised forests. 3. Iethods of felling, and theory of clearings, 4. Sowing, gathering, and preservation of seeds. 5. Preparation of the ground for sowings. 6. Season, and method nost to be preferred in different cases. 7. Plantations, perches, and poles. $s$. Cultivation of wood, and of drift sands. 9. Reboisement and creation of turf on mountains. 10. Pastures and protection against trespasses. 
In the cabinet of sylviculture, writes Senor Castel, for a practical acquaintance with the implements of labour employed in sylviculture, not only in Spain but also in the principal agrico-forestral ceutres abroad, there is located in the school a magnificent collection of 400 specimens of these, of perfect construction, and arranged with great taste. They comprise implements used in turning over earth, such as spades, hoes, pickaxes, two. prouged forks, rakes, weed-hooks, \&c.; together with these are those used in the surveying and treatment of trees, among: which the most important arc axes and saws of at great many different forms.*

There are also an abundance of mattocks, kuives, adzes, hooks, mallets, hammers, rammers, gouges, augurs, gimlets, scrapers, shears, \&c., \&c.; and there are not awariting thosc modest aids in sylviculture-sowers, planters, transplanters, pruners, \&c. Firuit gatherers, tree ladders, resin collectors, scrapers, resin tree openers, hooks tor use in rafts of wood, timber, scythes, de, complete the collection, which, when shown at some exhibitions, has had awarded to it the highest distinction granted for this class of objects.

This cabinet contains also a collection of 60 ploughs, harrows, rollers, levellers, rakes, scythes, axes, mattocks, two-pronged forks, and sowing machines, perfectly executed on the scale of ${ }_{4}^{1}$ th and $\frac{1}{6}$ th of full size.

In the studies of the fourth year are comprised xilometry; forest ordenacion and exploitation; forest industries; political economy and administration of law ; while drawing is practised continuous from the commencement of the curriculum till its close.

* Among the axes in this cabinet there deserve special notice the pruning hand-axe used in Arragon; the French hand-axe; the common axe with une eutting edge, hoca : the commou hatchet with lonk handle; axe used in cutting for resin in coch; small pitch-maker's hatchet for cutting pitch-wood; hatchet for splitting wood; Freneh. natchet for testing; pitch-maker s axe with shield; pitch-maker's hatehet without shield, for use on foot; testing hatchet with two edges, used in Cnenca; testing hatehet used in Jaen; pointed axc used in charcoil making in Cuenca ; comunon wood-eutter's axc; American testing axe; worknial's ave used in Segoria; testing and fellint axe used jn Jaen, called the Biscayan axe; axe of Dabie; axe of Chambray; ave of Micon, culled Taillende; Ixeipkig axe; firenaris pointed axe; marking hatehet uscei in forcstral districts; English wowdman's :x૯, \&\&. 
The programme of studies in Xilometry comprise $:-1$. A discussion of the general forms affected by the different parts of a tree; the geumctric and dendometric volumes of thesc. 2 . Description of dendumetric instruments, and the mauarement and comparison of thesc :3. The deterinination of the cubic contents of trees considered isolated or individually. 4. The apparent, and the real volume of wood; xilometers: description, comparisun, and use of them. 5. The determination of the normal co-efficient. 6. Methods of determining the value in respect of the weight and density of the timber. 7 . Increase of wood in crowth, and determination of future and of maximum increase. \&. The brauding or marking of timber.

In the cabiuet of xilometry are various compasses fur the determination of diameters in the trunks of trees; tape measures, and other metrical einctures; rules for marking of timber fit for cutting; ordinary circumference uneters; circumference meters of Bourart; dendrometer hy right angled triaugles; dendrometers by arc of a circle; dendrometers by the square or the perpendicular.

In comnection with the study of the ordenacion of forests for successive thiunings and felliugs, or the partition and arrangement of sections, attention is given to -1 . Detinitions of terms in use in Dasonomia, or forest science, a term derived from Daso forest, and Nomos law. The object of dasocracia and divisions of the subject. 2. The legal and natural condition of the forest. 3. Forestal condition ; dasometry, forest measurement; and dasography, or preparation forest maps. 4. Forestal condition, determination and survey of partitions designerl for fellings, and cpidometry, or measuration of the trees. 5. Selection of kinds of trees to be felled, and of treatment to be adopted; that of coppice-wood or timber forest, and duration of cycle of operations. 6. Methods of explortation; exposition of that devised by J. L. Hartig and by E. Cotta. 7. Rational or scientific methods. 8. General plan of exploitation. 9. Special plan of operations in the first 
period. 10. Determination of the maximum possible production ; reserves, and successive revision of scheme of exploitation. 11. Systematic management of irregular forests. 12. Valuation of forests, interest, dues, profits. 13. Value of the soil. 14. Value of the regetable covering of the ground. 1.5. Value of the forest.

The programme of studies under the head of forest industries embraces: -1 . The physical properties of different kinds of woods, and deductions from these relative to principal applications which may be made of them in civil and naval architecture. 2. The exploitation of primary and secondary products of forests; and the transport of these by land and water. 3. Storage, and storage charges of wood; its conservation by means of substances injected into it; and the preparation of wood pulp. 4. The collection of resin, and preparation of products derived from resin. 5. The preparation of charcoal, charcoal fuel, and potash. 6. Barking of trees, the disposal of bark, and the manufacture of cork. 7. Collection and preservation nf seeds for employment in manufactures. 8. Manufacture of oils, essences, and acids from forest seeds. 9. Panage and swine herding, aud ilisposal of prunings. 10. Trilisaion of dearl wool, branches, leaves, and peat.

In one section of the Cabinet of Forest Industry, foutined to objects fron: Spain, there is a collection of models representing a secherie for drying seeds; fanners for dislodging fine seeds; vertical and horizontal furnaces used in Sweden in the fabrication of vegetable carbon: three carts for transport; and peguiras, or piles of pine wood burnt to make pitch, from Sierra Segura; tools used in disbarking the cork oak, and in the manufacture of corks; and the more important implements used in the collecting of resin; various collections of wood arranged in hoards of different sizes, comprising specimens from the different provinces of Spain ; : ind a collection of 200 species of these woods, the produce of indigenons plants, arranged according to the method of Rossmoessler : coller- 
tions of charcuals and potashes, ashes, larks, resins, gnms, corks, esparto grass, and paluns.

In a second section, containing colunial products, ares preserved products of the Island of Cuba-a forestal collection presented to the school by D. Francisco de Paula, a member of the corps of forest engineers-composed of 36 cases, each containing leaves, branches, a board specimen of the trunk, charcoal, firewood, bark, and any other product of the plant to which it is dedicated, and a collection of woods comprising 200 specimens. Of products of Porto Rico there are two collections of woods in boards, and eomposed of 200 specimens of forest trees produced in that island, and another collection of woods in blocks from the same localing. Uf products of the Philippine Islands there are a collection of woods consisting of 90 species, comprising the principal kinds growing in the Archepelago, :and it rollection of textile materials, and articles fabricaterl uf fricestal products of the Plilippine Tslands.

The programme of stndy in the ardmmistration of justice comprises:-I. Fumdamental principles in regard to the State, the fovernment, and the Administration; and the charactor anl mange of the miministrative organisation of the comntry. 2 . The administrative organisation of the (nuntry, and territorial limitations of the anthorities, of the functionaries, and of corpurations in artive alministalion, in eonsultation, and in settloment of dispues. Duties and legal position of public empluyes in genemal: legislation in regard to administrative natters of general ipplication, snch as those relative to undertaking public. service, responsibility, \&c. t. General idea of ancient legislation in the branch relating to forests. 5. Special legislation relative to the facultative or professional, and the administrative service in the public forests; forest exploitations, delimitations, watching, fires, \&c. 6 . Transfer of property; acquisition of forests by the state; excambs; ex-appropriation. 7. Police of the State forests; penal portion of the ordinaness: forests belonging to private proprietors, 
The study in Political Economy comprises:-1. Definitions and general idea of the science. 2. Production and capital, and natural differences obscrvable in capital. 3. Natural agents concurring in production. 4. The study of labour; of the general conception of this, and of advantages and disadvantages resulting from division of labour. 5 . Idea of value in things; prices; interest. 6 . Influence of the quality and quantity of the production on the increase or diminution of population. 7. Consumption of products.

Drawing is practised from the commencement to the close of the professional curriculum. The instruction in this pertaining to what may be required in the work to which the students aspire, comprises:-1. Topographic drawing; the representation of lands, according to the generally accepter principles of procedure; hand-(lrawings, washed with China ink, or with an application of colours and conveutional tints. 2. Drawings of machinery, and elevations of buildings. 3. Phytographic ılrawings, or representations of species of vegetables. 4. Lasographic drawings, comprising plans or charts; phytographic, geognostic, forest partitions, \&c., \&c. 


\section{CHAPTER IV.}

\section{THE LIHRARY.}

Together with the liberal provision which has been made in the School of Forestry in the Escurial, for the prosecution of studies prescribed for candidates for admission into the corps of Forest Engineers in Spain, inclusive of an extensive museum, with apartments devoterl to the exhibition of implements and objects pertaining to rach department of study, and appropriate laboratories, ther is a spacious library, richly furuished with works treatiug of all the sulyjects embraced in the course of study. From the work of Sinor Castel on the foundation and levelopment of the school it appears that in 1877, when that work was published, th:re were in the library 250.5 scientific and professional treatises, comprising 5349 volumes of letterpress, and 316 atlases of plates, diagrams, and maps, pertaining to these works.

In these works there are supplied the means of prosecuting the study of any or all of the subjects brought under the consideration of the student in the class, or ntherwise engaging his thonghts -

6.59 treated of Mathematical Sciences;

231 of Physics ;

1189 of Natural History ;

15.2 of Ethics and Politics;

71 of Literature and Language;

\$:3 of History and Gengraphy ;

24 of Arts and Mamufactures; and

66 were Encyrloperdias or classed as Miscellanies.

The numbers have been increased since then, and every hranch of study is well represented. 


\section{Section 1.-Studies of First Year.}

As has been stated, the studies during the first year of the professional course relate to Topography, Integral and Differential Calculus, Descriptive Geometry, Applicd Mathematics and Applied Chemistry.

Sub-Section 1.--Applied Mathematics.

In the Library there were 6 works on subjects pertaining to Mathematics, 218 on Pure Mathematics, and 43.5 ụ Mixed and Applied Mathematics; in all, 1015 volumes.

\section{Sul, Section :-_- Ipplied C'kemistry.}

Amongst subjects to which attention is given in the study of applied chemistry is Tannin.

A good illustration of the mode and exhaustive character of the instruction given in Applied Chemistry is supplied by a treatise on Tannin by Professor Don Carlos Castel, which is is the command of the students. The subject in this is thus stated:-To determine the intrinsic value of the tannin or astringent substances pertaining to tannin, produced by the vegetables of five or more of the province of Spain, and in regard to each to state with the nearest approximation attainable, the age of the plant, and thereafter its growth, habitat, seasons of the year most favourable for the collecting of the produce, and the routes or means of export or transport of this to market; a treatise adopted by the Royal Academy of Exact Physical and Natural Sciences at their annual meeting in 1876 .

In the introduction to this treatise, citing words with which M. J. Pelouse in 1833 opens his valuable work on tannin and its sources, to the effect that there is no organic substance, in regard to which there have been so many enquiries, and yet in regard to which the history is so greatly desiderated-Senor Castel cursorally reviews what had been done by chemists in different countries during the forty years pre- 
ceding the date of his memoir. In successive chapters he discusses the nature and properties of tamnin; the question, Is the tannin contained in different vegetables identical? and the physiological action of tannin. Treating next of analysis, he states the gencral ideas involved in these; examines different methods of analysis; and gives -1 . A detailedexposition of the methods of Monier and Lowenthal; lie then gives tabulated results of analysis performed (o) deternine the quantity of tannin contained in different plants; analysis performed by various observers giving the popular and scientific names of the plants; conditions of the plant in regard to age, or anght else deserving of notice, in regard to the season of the year at which the bark was collected, \&c. ; the part of the tree subjected to an analysis, the percentage of tannin obtained, and the name of the experimenter. 2. Analysis made by Neubauer, giving specitication of bark operated on; the percentage of taunin soluble in cold water; the additional percentage obtained by solution in warm water, and the sum of the two. 3. Analysis made by T. Hartig, in regard to which are specified relating to the material, a number of particulars, including the part of the oak whence each was taken, fruit, bark, leaves, or roots; the character of the forest-timber-forest, coppice-woor or medium; from what part of the tree the bark was taken, the degree of shade under which it grew, and the season of the year at which it was collected-some of these particulars being givcn in regrard to sume, others in regard to others, of the specimens "perated on, and all of these strictly classified. There are stated then the yuantity of extract obtained from a gramme of material in the open air, according as this was in winter, or spring, or in both; next, the tannic acid contained in one gramme of dry material, as calculated by the volumetric method, and as calculated by precipitation, and in both cases according as it was in winter or in spring, and in many cases in both. 4. Analysis of plants gathered in Spanish localities, in which are given the numes of the plants; the province and the pueblo or 
lowuship; the age of the plant; the month in which it was gathered; the portion or part of the plant analysed; the colour produced by the salt of iron, and the tanniu contained in 100 parts of dry material; and the results of experiments on the influence of light.

In the next chapter are discussed tanniu plants, and causus determining the greater or less abundance of tannin, under the headings of general ideas, flowers, fruits, leaves and galls, barks, and determination of the times most favourable for the debarking of the trees in regard to the conservation and development of these; does the richness of the barkings vary with the season in which the debarking occurs? the age at which the debarking should be executed, and the methods of utilisation most convenient for the Casquizales ; the influence of heat, humidity, soil, and light on the production of the taunin; methods of disbarking trees. And the chapter closes with a detailed account of the principal lignous plants made use of in the tannin industries.

Section 2.-Studies of the Second Yeal.

'The studies of the second year embrace, as has been stated, theory and application of Mechanics, Geodesy, Ileteorology and Climatology, Construction and Drawing.

\section{Sul-Section 1.-Meteorology and Climatology.}

In Spain, as in other similarly situated countries-in which are included some of our colonies and dependenciesquestions connected with meteorology and climate, and as pertaining thereto, means of preventing lisastrous consequences from drought, torrents, and inundations, and of securing an equitable diffusion in time and space, if not also an increased rainfall, and humidity of soil and climate, are of importance.

In illustration to what students have thus been trained to attempt and accomplish, I may refer to papers of 
forestral, meteorulugical, and other conzate subjects, by Seuor Dou Riafael Alvarez Sereix, member of the Corps of Forest Engineers, au eléve of the School of Forestry, and now Director-General of Geography and Statistics in Madrid, which have appeared in Spanish periodicals, and becu re-publshed in two series, entitled Estudios Butanicul'orestales; and others which have been published in a volume entitled C'uestiones Cientificas, copies of which are at the command of the students.

Unc of the papers published by Senor Alvarez, under the title of Estudios Botanicu-Forestales, is entitled 'The Influence of Forests on Climate,' based on the valuable treatise on the sulject by M. A. C. Becquerel. In this the term rendered forest is used as one applicable to a considerable extent of country covered with a spontaneous growth of an arborescent vegetation. And following Humbuldt, the author says the climate of a country is the result of the calorific, aqueous, aerial, luminous, and electric phenomena, which may cause one determinate locality to prescnt a different meteorological character from another of the same latitude and geological conditious.

Assuming that of the influences specified heat exercises the greatest influence, and next to this the quantity of the rainfall in the different seasons of the year, and next to these the humidity or aridity of the air, the predominating winds, the number and distribution of storms in the course of the year, the degree in which the heavens are clouded, the nature of the ground, and of the vegetation covering it, and whether this be spontaneous, or the result of culture, Senor Alvarez proceeds to discuss the questions which will determine what is the effect of woodlands on the climate of a country, which questions he assumes to be these:-

1. In what degree do the forests act as a protection against the winds, and in what measure do they retard the evaporation of the water of the rainfall ?

2 . How do they modify the hydrometric condition of the surrounding atmosphere by absorption by roots, and by evaporation from leaves? 
3. How they modify the temperature of a country?

4. Have forests any influence on the rainfall as to its frequency, or its abundance and distribution, and do they regulate more or less equally the flow of streamsand springs?

5. To what extent do they prevent the ernsion of mountains and lesser slopes?

6. Do forests draw off electricity from thunder-clouls, and if they do so do they to an extent corresponding to this action effect the region of the woodlands? And

7. What kind of influence do they exercise upon the public health?

But with these preliminary points determined it is necessary, he says, in order to determine the effects of forests on any district, to know also the geographical position of this, its geological character, its liatitude, its proximity to or distance from the sea, the composition of its soil, and of its subsoil, and whether this may be permeable or the reversecalcareous or argilaceous-all of which particulars can only be determined by observation. Aud he further states that the action of forests on the climate will be more or less pronounced accorling to-

1. The extent, elevation, and nature of the soil and subsoil.

2. Its exposure in regard to heat or cold, and in regard to the humidity or aridity of the winds.

3. The season of the year in which fellings are marle: whether the kinds of trees be those with deciduous, or with persistent leaves; and the evaporation and radiation going on in the different seasons.

4. According as the season of rains be the spring, the autumn, or the winter; and

5 . 'The proximity of pestilential lakes, \&c.

All of these points are discussed in an exhaustive manner, commencing with a permeable soil with a permeable subsoil, and a permeable soil with an impermeable subsoil; and an impermeable soil with an permeahle subsoil, and an impermeable soil with an impermeable subsoil. 
Another of the papers published by Senor Alvarez is one under the title Trabajos de Ebermayer. On the works of Ebermayer, in which are discussed successively the influence of forests on the humidity of the atmosphere; on the bumidity of the ground; on the temperature of the ground; on the temperature of the atmosphere; and on the constituents of the atmosphere.

The views of Ebermayer are also brought furward at great length in a brochure entitled Breves Consideraciones sobre Estatica Quimica-Brief remarks on forestal chemical statistics-by Senor D. Luis de la Escosura y Coronel, Chief in Corps of Forest Engineers. In this the author sought to give as detailed an analysis as possible of the valuable work by that distinguished Professor of Agricultural Chemistry and of Geognosia, in the Royal Central School of Forestry at Ascaffenburg, entitled lie gesammite Lehre der Waldstreu, mit Kuecksicht auf die chemische Statik des Waldbaues. Unter Zugrundlegung der in dem Kœnigl, Staatsforsten Bayerns angelstellten Untersuchungen-a work, to follow a description given of it by M. Grandeau, methodical in the highest degree, and written with sobriety and lucidity, the perusal of which is lightsome and interesting, notwithstanding the numeroits statistical and analytical data which it contains; and beyond all manner of doubt one of the most important forestal works of our age.

The author commences with the study of the formation of the covering of the forest ground; that is of the conditions of the fall of the leaves, comprising the causes, the times, the quantative importance according to species of trees, the altitudes at which they grow, \&e. In the second chapter he takes up the data procured by analysis, in reference to the chemical composition of the ground covering, and of the wood: determining thus the chemical statistics of the forests. In the third he brings under consideration the physical properties of that covering, and the influence which this exercises on the physical properties of the ground. In the fourth, attention is given to 
chemical modifications experienced in the ground-covering of forests, and its chemical action on the ground. In the fifth and last chapter are brought under consideration the influence on the forest of the removal of the leaves and other dehris constituting the ground-covering of the forest. In an appendix is given a statistical comparison between agricultural and sylvicultural productions, and tabulated statements of numerous data which had served as a basis for the conclusions of the author.

In 1879 was published a brochure entitled Inundaciones y sequias medios de defensa-Informe redactado por acuerdo le la Junta Directiva de la Sociedad Geografica de Madrid, con motivo de la Inundaciones de Murcia; por El Exmo, Senor Don Frederico de Eotello y de Hornos-which is full of important and interesting details, illustrative of the production of torrential rains, and consequent torrents in mountainous regions, and wide-spread inimulations on plains; all which, it is shown, might in many cases, if not, also in every case, be prevented by planting the basin receiving the rainfall with herbage and bushes and trees.

In the following year (1880) was published, Llurias e Inundaciones: Distribucion general de las aquas en toda la superficie del glolo y particularmente en Lspanna; Torea de las Avenidas, de los rios y medios de evitarlas y resistirlas; por D. Vincentè de Vera y Lopez, Doctor en Ciencias, Quimico del Ayuntamiento de Madrid; con un prologo, de $D$. Manuel Mariu Jose de Galbo.

After notices of the general distribution of the rainfall over the surface of the globe, and illustrations of the effect of circumstances upon this, the author takes up the consideration of the rainfall in different regions in the Peninsula, and the local conditions of these. There is given then an exposition of the theory of floods, with details of the action of geographical position in regard to latitude on varying degrees of humidity in the atmosphere; of the influence of the geological character of the gronnd; 
details of different phenomena of rivers flowing over permeable and impermeable lands; of the action of vegetation on the rainfall. Passing then to the consideration of great inundations, details are given in regard to inundations of the Amazon, of the Mississippi, and of inundations within the temperate zones, and local conditions by which they are affected. The author next proceeds to the consideration of torrential inundations in Spain, in Almeria, and in the basin of the Lorga; floods of the Sangonera and of the Segura; floods in the great Cuencas; inundations of the Duero and of the Rodano ; and the inundations of 1857. Information is given in regard to the efferts of inundations, and to the alluvial deposits left by inundations. There follows a review of the hydrography of the Peninsula, in which it is shown that to the mountainous character of the country is attributable the fact that there are no great rivers there; with notices of the various slopes of the country toward the sea, and of the districts included in each. In discussing means of preventing inundations there are brought under consideration, in succession, the contour of the country, and the effects of vegetation; the geological character of the ground in each locality; the permeability of the ground, puntanos, or large reservoirs; lateral or littoral deposits; canals; the riches lost in the sea; and the extent to which the water might be utilised.

In the conclusion of the work the anthor refers to the importance of international arrangements of meteorological observations, and of works designed to prevent the abrasion of the banks of river's by dykes and other works of defence, a measure which had commanded attention in many countries.

The advanced forest economy of the day is based on scientific observations, and scientific reasoning. In the first-formed schools of forestry, such as those nuder Hartig and Cotta, observation was combined with instrnction and practice. The importance of this was felt deeply by two German foresters, Handshagen and Von Wedekind, and in 
1826 the latter marle an effort to organise a society to conduce to prosecuting forestal experiments, but did not succeed. In 1S68, at a congress of German foresters, heli in Vienna, the sulject was brought under discussion. A committee was appointed to consider on what plan such forestal experiment stations as were considered desirable should be organised. 'They agreed'-says Mr Adolphe Leue, in a paper read before a Convention of the Ohio State Forestry Association, held in Cincinnatti in August, 1883- On a plan of organisation, and questions to be subjected to investigations and experiments. The report was adopted by the German Foresters' Cougress, and submitted to the several Governments, which were to hear all the expenses of these stations.

' The first station was organised on the 16th April, 1870, at Baden, Saxony, Prussia, Wurtemberg, Austria, Ravaria, Brunswick, and Hesse followed in the order mentioned.

' The great aim of these stations is,' he says, 'to furnish a scientific foundation for a rational management of forest,based upon exact experiments and careful investigation. They are intended to determine the significance of forests in the economy of nature, to try the various methods of forest management, to examine the advantages which one method may have over the other, and, finally, to establish a plan of forest administration, which will enable the owners of forests to realise the greatest possible profit from forests, and at the same time reduce the expenses of their administration.

'Among the many problems to be solved through the agency of these stations, are the following: to determine the influence of forests upon soil and climate; to investigate the relative value of the several methods of thinning; (1) establish reliable tables of increase, and methods of valuing forests ; to study the foes of the forest, both animal and vegetable, and to devise means of successfully com- 
bating them; to determine the value of forest-litter upon the growth of trees; to test the relative valine of forest implements; to devise new methods of obtaining forest products, and to find new uses for the same ; in short, they are intended to furnish the means by which to increase the wealth of the owners of forests, and thus that of the entire country, and to furnish legislative bodies with the foundation necessary for a just taxation of forests, and for a wise and beneficient code of forest-laws.'

These stations are State institutions, connected with schools of Forestry.

In Prussia, with the Forest Academy at Eberswalde.

In Bavaria, with the University at Munich.

In Saxony, with the Forest $\Lambda$ cademy at Tharandt.

In Wurtemberg, with the University of Tuibingen.

In Balen, with the Poletichnicum at Carlsmihe.

In Thuringia, with the School of Forestry at Eisenach.

In Hesse, with the University of Giessen.

A desire was felt by eléres of the School of Forestry in Spain that they should be enabled to join the union, and take part in the prosecution of observation and experiment; and that to them should be allotted observations connected with meteorology and climatology: and in 1882 was published, under the title Estucion Meteorologica-Forestal de San Ildefonsa-a project for the creation of a Meteorological-Forestal Station in San Ildefonsa-which had been presented to the Minister de Fomenta in the year 1874 , by the Commissioners entrusted with arrangements for the systematic management of the forests of Balsain, a royal appenage in the vicinity of Madrid, lying between that city and Guadalajara. Having stated and detailed the origin of the union, the writers add: 'Since September, 1872 , there have been conformed and brought into reciprocal communication the stations of Prussia, with those of Wurtembers, Batlen, Hesse, Bavaria, Savony, and 
Thuringia, according to an agreement adopted at a re-iunion of German foresters held in Brunswick. The stations in Prussia are ten in number, besides other three which have been created in Alsace-Lorraine. The regulations of these stations were made on 11th March, 1872, and according to the arrangements made the central station is organically united to the Academy of Forestry in Neustad-Eberwald; and all the others are subordinate to this. In general, the studies or investigations are divided into five sections - the forestal, properly so-called; the chemico-physical; the meteorological ; that of vegetable physiology; and zoology. But the central station has the whole of these sections, the others have only forestal and meteorological sections, or only one of these.

Referring then to the stations in Bavaria, under the direction of Dr. Ebermayer, as models deserving of imitation, there are stated the points to which attention is given in these; and the results which might be expected from the consideration of data obtained. There are next described what apparatus it would be desirable to have, and suggestions are submitted in regard to the organisation and service of the station proposed, with an estimate of the prices of at which the apparatus might be procured in Munich, amounting in all to 1570 pesetas or francs - of the expense of establishing the observatory amounting to 550 pesetas, and of the probable annual expenses amounting to $2 \mathrm{i} 50$ pesetas. So far as known to me nothing resulted from this memorial in the form submitted for consideration; but the matter to which it had reference has been taken up, in connection with the other arrangements made for the study of aspirants to the forest service of the country, in the School of Forestry in the Escurial.

\section{Sul,-Section 2.-Const?uction.}

In the same year, under the head of construction, attention is given to the construction of forest-roads and highways, bridges, sheds, forest huts, and homes for forest officials, 
who are required to reside permanently or occasionally within the precincts of the forest; and to works of hydraulic engineering: wells, tanks, canals, and works of irrigation. In connection with the information which has been given in regard to published works, to which the students bave access, on matters pertaining to meteorology and climatology as departments of forest science, I think it well first to make mention of works on hydraulic engincering, and thereafter to advert to works connected with the others.

Of treatises on subjects pertaining to hydraulic engineering the most instıuctive is one entitled Tratado de aguas y Kiegos, por Don Andrés Llaurado, Ingeniero de montcs Jefe de Primeri Clase, Professor de C'onstruction y Mecanica Aplicata en la Escuela especial der Cuerpo, \&c., \&.c.-A treatise on rivess and irrigation works, by $\mathrm{D}$. Andrés Llaurado, Chief of the first-class in Corps of Forest Engineers, and Professor of Constructions and Applied Mechanics in the School of Forestry. It is a treatise which, published in 1870 , has reached a second edition, and meanwhile has procured for the distinguished author high honours in orders of knighthood in his own country, in Portngal, and in France and Italy,- and membership in numerous scientific and agricultural sncieties in different parts of Spain, in Russia, in Italy, in Piedmont, in France, and in the United States of America.

After an introduction, in which is given a brief review of irrigation works in Spain, and a statement of economic considerations involved in the enterprise, and of means by which it might be further developed, the author devotes the first part of his treatise to preliminary matters, discussing in successive chapters:-1. The importance of irrigations, and the climate of Spain. 2. The composition and nature of waters of irrigation, and their effects on vegetation, and on different crops. 3. The quantity of water required for irrigation. 4. The price of recovering water, and employing: it in irrigation, 5. The current or flow, and the leading 
off of water. 6. The distribution of water led off, and the effecting of this in determined proportions. 7. The distribution of water in fixed quantities.

The second part is devoted to the consideration of meaus of procuring water, in regard to canals of irrigation; and after determining preliminaries, there are discussed schicmes of uperation and works of cxecution. In regard to reservoirs, there are discussed eertain general principles counecterl with them, and the construction of them; followed by atl account of reservoirs in Spain. Fountains or springs firom subterraneall sources are next discussed, with special refierence to the discovery and opening up of subterranean supplies; the greological strata, and the general conditions of the strata in which they exist; the directions in which lhe water Hows in subterranean channcls; the most favunable points for discovering these; the depths at which they exist; the delivery which may be expected from then ; rules proposed in olden times for discovering and upeniug up such supplies; and different methods which have been cmployed in moderu times; artesian wells; laising of water by mechanical appliances; machines which ale in use.

The third part is devoted to irrigation, and there are discussed the irrigation of arable lands, and of meadows. In connection with the latter are discussed certain prelimiuary matters; general ideas regulating the operation; and methods employed.

The fourth part is occupied with the reclaiming or improvement of wet lands. Here are brought under discussion drainage; warping; drying up of lagoons; leclaiming of land from the sea; the planting of sand dunes in Andalusia; and the reclaiming of salt soils.

Such are the contents of the first book. The second book is devoted to works of irrigation in Spain. In succession are brought under consideration those on the Northern or Cantabrian slope of the country; those on the Western slope; those on the Southern Oceanic slope; those on the Southern Mediterranean slope; 
and those on the Eastern slope. In regard to each information is given relative to the lands and water supply, and to irrigation works of every description mentioned in the previous book to be found in the basins of the different river's by which it is traver'sed.

There are several works ou irrigation, and matters pertaining thereto, in the Spanish language, and distinct references to these are given, in some cases with copious citations.

Uncler the liead of forestal coustructiou, in the programme of studiy followed in the School of Forestry, is comprised also the construction of forest huts and homes.

In connection with this department of study there were published iu 1582, Proyectu de una casa, parce Guardas de mmutc y Cuputaces de Cutivos, en la Dehesa del Moncayo de Turazonu, por José Bragat, Ingeniero, Jefe de montes y Jẹie del Dictrito Forestal de Zuragazu; and in 1885, Proyecto de casa de Giunrlas ura el monte Pelonno.

And in illustration of the character of the studies pursued in this department, I may cite these projects, and estimates for the erection of forester's' houses. The first is a project for the erection of forest cottages for lorest warders, and foremen superintending planting uperations in the pasture lands of the Moncayo of Tarazoua. In this are given details of the zone of the Moncayo; of the pasture grounds in question; of forests comprised in these, or adjacent thereto; and such information in regard to all of these as might be leemed necessary to the forma. tion of a correct opinion of the necessity or importance of the work. The papers to which this is iutroductory consist, in accordance with Article 8 of Regulations for the carrying out of the law of 11 th July, 1S7T, of specifications of the works required; of the materials to be employed; of the manner in which the works are be cxecuted; and general arrangemeuts in regard to reporting the progress of the work, and the taking over of this when completed. It was prescribed that the work should be done by contract, 
and executed within a specified time; and there are appended to the specitications a tariff of different wages to be allowed to different kinds of workmen; of charges for means of trimsport of material, including drivers; and for lading, trausporting, and discharging the loads, based on the cubic Ineasure of the whole, or by cubie metre per kilometre of distance; of payments to be made for excavating carth, accurding to specitied unit of mestsurement; a statement of the average distances of transport fiom different localitics, with accounts of the quality of the materials yielded by each; the condition in which these exist, and that of the state of the roads from those to the site of the building; and a statement of the expense of the severil works, according to these estimates, with a summary of the whole, which amounted to $6+99 \cdot 15$ pesetas-to which was added, to cover unforseeu expenses 1 per cent. 64.99 ; expense of direction and administration 5 per cent. 32.96 ; profit to contractor, including 3 per cent. for money advanced, 9 per cent. 584.92 ; in all, $7+7+02$. To the whole are added general directions issued by the directory of public instruction, agriculture, and industry, to be followed in the erection of the house.

The project and specifications, and estimates, included the furnishing of a room for the use of the forest engineer when visiting the district. This comprised a sofa, bedstead and bedding, wash-stand, cupboard, writing table, lamp, drawing-board, and all resuisites for the preparation of charts and reports-the sum allowed for all which was 400 pesetas, and this was included in the general estimate.

The second was a project for a warder's cuttage in the Pelonno forest, with plaus and elevations. In this the preliminary statement was more brief, but the tabulated statements more full. These comprised specifications of measurements; estimate; of expenses of each kind of work, according to unit of measurement; general estimate of the whole, and summary, with additions of 5 per cent., and of 9 per cent., giving a totil of $100 \times 8632$ pesetas. 


\section{Section 3.-STUdies of T'Hikd Year.}

In the third year of study attention is given to Mineralogy and Applied Geology; to Applied Zoology; to $\Lambda$ pplicd Botany; and to Sylviculture.

\section{Sub-Section 1.-Mineralogy and Cieology.}

Besides other works on geology and mineralogy, therc has been published under the title of Lecciones de Petruraplia Aplicada Expiicada en le Escuela Especial de Ingenieros de Montes por el Ingeniero del Cuerpo y Pro. ficssor de la misma D., Juan José Munnos de MLadariago, Lectures on Applied Petrography expounded in the School of Forest Engineers by Senor Munnos, Forest Engineer and Professor of Mineralogy in the school. In this are given letails in regard to some 600 different rocks, including the scientific and the popular names under which they are linown, and is a work spoken of in terms of high comInendation by the Junta Consultativa, or Council of Advice, of the corps, by which the publication was recommended.

In this volume, after some preliminary observations, notices of the bibliography of the subject, and a definition of the designation, there are discussed :-

1 Under the head of Hilolgy the division of rocks according to their constitution, with the distinctiou between phaneromeric and cryptomeric rocks.

2. Under the head of Histology there are discussed the forms and dimensions of the elements of rocks; the forms and structure of accessory masses; the general forms of structure; particular structures of rocks; cross sections and fractures.

3. Under the head of Morphology are discussed forms of stratification, of aggregation, and of concretion.

4. Under the liead of Syuopsis there are given the classification of Naumann, with a tabulated classification of the rocks according to this; the classification of rocks, according to Cordier; the classification of rocks 
considered mineralogically, according to Broigniart; the classification of rocks considered mineralogically according to D'Omalius : D'Halloy; the mineralogical classification of rocks according to Coquand ; the classification of Coquand modified by Vilanova; and the dichotomous classification of rocks. The different species are then described according to classes, and orders, and families.

5. Under the head Petrogenia are discussed successively eruptive rocks and neptunic rocks, in a normal condition, divided into those formed by chemical sediment, and those by mechanical sediment; metamorphic rocks, and rocks of organic origin, divided into those formed of animal remains, and coal formations of vegetable origin.

6 . Under the head of Aleofologia, or the decomposition of rocks, are discussed the various rocks thus produced. And this is followed by a discussion of the general constitution of earths; of the component parts of these; of the influence of these upon the properties of the earths thus formed ; the physical properties of earths ; and the classification of earths according to the method of Hundeshagen of Masure, and of Columelo.

Of this sixth section of the work the Junta Consultiva speak in terms of the highest commendation.

It appears from their statements, and the statements of others, that facts which are met with scattered and dispersed in various treatises on sylviculture, mineralogy, geology, and other allied subjects, are here presented in such collocation and combination that with ease and advantage there may be deduced from the composition of the suil the vegetation with which it should be covered, and vice versu; and be determined with certitude the case frequently submitted to the forest engineer-to what should be destined certain lands requiring to be replenished; or what species of trees should make way for others for which the land is better adapted: and this department of study is presented in the work in a simple and attractive aspect, deducing so naturally from the composition of the soil, and the course of the alterations in the nutritive principles 
which it contains, and from its qualities, physical, chemical, and mechanical, the requirements which should be satisfied, and the relations which, within definite limits, should exist between the soil and vegetation which it prefers - that in this part of the work the forest engineer has a safe guide in the discharge of one of the most important of the services required of him. They allege that Senor Munnos has (it may le unintentionally, but not on that account the less meritoriously) so carried out his idea as to elevate it to a place amongst those ideas which are of much avail in the development of the practical applications made of physical science; showing that appliances which are oftimes found to be a burlen on the memory appear as corollaries or consequences like to those which are derived from mathematical problems, and satisfying suspicions and doubts which naturally arise as the horizon is extended, by the demonstration that what happens could not but happen, and could not have been brought about otherwise.

\section{Sub-Section 2.-Applied Zoology.}

Like attention has been given to provision for the study of Zoology and Botany in their application to forestry. An extensive acquaintance with both sciences is a pre-requisite to admission to the school in the Escurial, but the information otherwise obtained has to be brought to bear upon phenomena presenting themselves to the forest engineer in the discharge of his functions, so as to secure the conservation and healthful development of forests under his charge or administration.

What may be considered a handbook, which may be used in diagnosing vegetables and animals coming under his notice in connection with his profession, as might be used the Petrography of $\mathbf{M}$ unnos in diagnosing rocks and soils, is a volume entitled Claves Dicntomicos, para la determinacion de los typos, ordenes y Familias, en los reinos, animal y Vegetal, by Senor D. Adulfo Parada y Barreto, Forest 
Engineer-in-Chief of the second class, and Professor of Applied Zoology in the School of Forestry. .

And information in regard to methods of prosecuting microscopic investigations, so necessary in the study of entomology, in relation to injuries done to forests by insects, is embodied in a volume printed by Royal order, under the title La Estacion Zoologica de Napoles, y sus procedimientos, para el examen Microsopico, The zoological station at Naples, and its proceediugs by microscopic examinations-a memoir presented to the illustrious the Director-General of Agriculture, Industry, and Commerce, by Don Joaquin Maria de Castellarnau y de Lleopart, Forest Engineer.

lllustrations of the practical application of a knowledge of entomology, to the study of damage done to forests by insects, are supplied by a memoir entitled, Estudia de la Invasion de los Montes de la Provincia de Salamanca, del Insect llamado vulgarmente Lagarta, y medios mas adeocuardos, para evitar sus estragos-A Study of the Invasions of the Forests of the Province of Salamanca, by the insect popularly called Lagarta; and the most efficient means of averting its ravages - by Don Antonio Garci Maceira, Forest Engineerin-Chief of the serond class.

In consequence of great devastation being occasioned in the forests of Salamanca by an insect, the increase aud spread of which was imperilling the existence of the woods and forests in the province, by Royal order of 21st May, 1883 , a commission of enquiry was appuinted ; and Senor Maceira was entrusted with the commission. He proceeded to the province, prepared a report, which was submitted for examination to the Facultative Junta, or Professional Council of Forests, by whom it was highly approved, and its publication for general information was advised. This approval and advice were forwarded by the DirectorGeneral of Agriculture, Industry, and Commerce, to the Minister of Fomento, and publication followed.

In the memoir by Senor Maceira there is given the history of the invasion and its rapid spread; there follow 
notices of the generic and specific characters of the insect, and of its nutural history, with general observations on the causes and occasion of its rapid increase in the province. There are adduced climatic observations, with statements of contributory effects, direct or indirect, which climatic conditions may liave had in favouring the rapid increase of the insect. There are next stated effects which may be attributed to the diminution of carnivorous insects, parasitic insects, and insectivorous birds, with references to the occasion of this. Next are specified extensive changes which had taken place in the culture of different crops in the district, but not in adjoiuiug districts, with the effects of diminishing the woodlands in it, and so affecting the climate; of starving out certain insects, and as a cunsequence dimiuishing the aliment of insectivorous insects and birds; and, as a secoud consequence, leading to the diminution of these, but increasing at the same time the vegetation supplying food for the langarta-the Iombyx Dispar of Latreille, the Liparis Dispar of Linnæus; and thus producing an extraordinary increase of the insect, and of its ravages in the forests, with disastrous consequences. Next, with courtesy but firmuess, there are reported as contributory causes the apathy and negligence of the people; the unsatisfictory condition of the municipal guard as forest watchmen, and that of watchmen supported by private proprietors of forest lands; and in connectiou with this the inefficacy of the law as it exists to secure the destruction of injurious insects; and the desideratum of associations of forest proprietors and foresters for consultation and action in matters affecting the interests of owners of forests and woodlands.

A more commanding illustration of the application of the knowledge of entomology to the averting of a threatened calamity is supplied by what occurred to Spain, on the invasion of Europe by the Phylloxera vastatrix. In many of the vine-growing communities of Europe, on the appearance and rapid spread of the Phylloxera, there was great 
and wide-spread consternation, and that not without reason. Spain was not an exception to this panic, but at once the forest engineers in various parts of the country came to the front spontaneously, or at the call of the Government, or the entreaty of their compatriots, and the result showed that they were thoroughly competent to deal with such a case. It would fill a volume to detail what they did in prescribing and advocating preventive protective measures, which were adopted and proved eîncient; and what they did to expose the insufficiency or other means which elsewhere had become famous. Details of what was done in both of these departments of operations are embodied in a report, published by Governmeut, by His Excellency Senor D. Mariano de la Paz Graells, Proiessor of Comparative Anatomy and Physiology, in the University of Madril, entitled La Phylloxera vastutrix. In it is a large volume with an atlas of illustrative plates. It gives cletails of the natural history of the insect; of what had heen published in regard to it elsewhere: and of what haul been done to avert the evil in Spain and different parts of Europe.

\section{Sub-Section 3.-Applied Botany.}

As with the provision made for the stully of Applied Mineralogy and Applied Zoology, so with the provision made for the study of Applied Botany. It was, as might have been anticipated from the immediate relation of botany to forestry, still more copious.

One valuable contribution to the provision made for aspirants to the membership of the corps of Forest Engineers, enabling them to make themselves acquainted with the latest discoveries in modern forest science, are various publications by Senor D. Rafael Alvarez Seriex, of some of whose writings mention has been made. Amongst these are Geografia-Botanica; and Estudios Botanico-Forestales. Of the latter two series have been published, most of them 
being translations or resumés of papers or larger works by men of note in other lands, given in a flowing popular style, attained without detriment to the scientific precision of the original-or papers giving the result of his own observations, or of observations made by others under his eye.

With these may be classed one entitled Incursion por la Botanica. Of this,the following translationwill supply a better idea of his treatment of such matters than I could give by a brief notice or summary. The design was, as may be seen, to supply an indication of the state of botanical science among students of forest science; and taking as a notto that line of Virgil, Felix qui potuit rerum cognoscere causas, be proceeds:-

' The vegetable world presents to the view of the attentive observer who studies it, marvellous charms and mysteries of complicated and but little comprehended organisation; all in beantiful harmony with the eternal Hosannas which heaven and earth are giving forth; prolucing admiration, and presenting motives prompting the spirit to meditatethe infinitely great, but also the infinitely small; the milky way, with the innumerable stars of which it is formed. but also the microscopic ephemera, which is born, lives, and reproduces its kind, and dies all in a space of time of a few moments duration. So many and such are the transformations of matter brought ahout by vital force, the reality of which is indisputable although its essential nature is unknown, that not even imagiuation can grasp such an immense combination, in which it appears as if we found an intinite within another infinite, and in wondrous harmonious co-uperation, always working, and always unvarying, the laws by which all is moved by the Sublime Arcinitect of so grand a work.

'Shall man go on progressing without end? Will there come a time, more or less remute, in which he will be able to give account of the causes originating all that comes under the cognisance of his senses? We believe not. $\mathrm{His}$ perfectability is limited with bis intelligence; there is 
something at the hottom of all the problems which he proposes to himself to solve that is inherent to his own personal imperfection. He does not know the connection of the subjective and objective ideas; and in his laudable endeavour to obtain possession of the truth he encounters obstacles which he cannot remuve, and which it is not given him to interpenetrate and fill.

'It became possible, after a lapse of centuries, and continued observation, to discover the existence of sexes in plants. The middle ages having passed a dark night of human intelligence, Camerer wrote his famous letter in 169t, in which he declares that the anther is the fundamental portion of the flower; and somewhat later, on the 10th of July, 1717, Vaillant delivered an erudite discourse rejecting the hypothesis of Samuel Mlorland, and affirming that " the stamens traus nit to the ovules - not the grains of pollen-lut the vapour or volatile spirit, which is emitted hy them ;" and J. B. Amici examines the Pcrtulacu oleracca (a species of the Purslane), and opens to science, with his description of the pollen tube, a wide field for investigation, in which there distinguished themselves Broigniart, Schleiden, Fritzsche, Mohl, Hofmeister, Radlkofer, Schaeht, and many other distinguisher naturalists. Let us study the progress of fecundation; let even the different speed with which the pollen tube advances from its formation be determined; let it be followed, and be seen to penetrate the microphile, in which it shows a remarkable incisory force-and this having been done, when the triumph seems complete and the phenomena explained, there presents itself the insuperable difficulty of ascertaining what may be the action of the extremity of the pollen tube upon the embryotic vesicle, from which it is kept apart. by a membrane which is not perceptibly modified, ar,d the basis being awanting we begin to diverge into the dangerous field of hypothesis-ingenious, no doubt, but it may be far from correct. 
'What a beautiful world is the world of plants! and what a time man has lived without giving to them the attention they claim, believing them to be the gratuitous gift of nature-manna which might be enjoyed without any trouble about its preservation! A silent and solitary world living by itself alone: a beautiful carpet which covers the earth, and forms, with the blue of the heavens, a landscape of charming lovliness such as no paintersnot even the most illustrious-have been able to depict and perpetuate upon their canvas! Overwhelming is the thought in considering only the infinity of the numbers of the individuals of which it is composed, from the gigantic Wellingtonia, whose head is lost in the clouds at the height of a hundred metres, and the twisting twining Calamus, a thousand yards in length, to the Moss and the Lichen, which cover with green tints the abandoned lordly towers; or the Algae, which float lightly on the waters of the murmuring brooks. Just as they exist on the burning sands of Africa, and quench by their juice the thirst of the lost caravan, and with their shade protect from the burning rays of the sun, and cover and save from the terrible Siroccu, are they found likewise in reduced size in the regions of perpetual snow.

'It is they which mainly contribute to keep the atmosphere in fit condition for the support of animal life. During the day their cellules, which contain chlorophyll, tix the carbon for the growth of the plant, and set free the oxygen, for which great blessing we are indebted to them as a boon, as thus we owe to them life and unappreciable joy, to which we cling the faster the nearer we are about to finish our pilgrimage and go.

- Vegetables are also vast deposits of solar heat, which they store up and keep by their chemical action, assimilating it for their growth, and which they subsequently give forth entirely and withont reserve, so that, as was aftirmed by the unfortunate Lavosier: In nature nothing is lost, and 
nothing created. These mines of coal, of which London consumes annually six millions of tons - what are they but immense antediluvian woods hidden by geological deposits? We can fully enter into the views expressed when interpreting, for the first time, the movement of the locomotive on roads, Stephenson said to Buckland, who was looking on with astonishment, "Do you know what gives movement to this machine? The sun, which more than than two million years ago darted to earth with its rays of light, those same fires which are now to-day converting the water into steam."

'Blissful nations are ye in which all the importance which it deserves is allotted to the vegetable kingdom, and in which it is studied in its different manifestations, with a view to secure to it all the means of life which it requires.-Nations in which a tree is sacred, and forests are not devastated to meet some momentary requirement, without any eye for the future! Base spirits are they which reck on for merit their hardihood, and their ignorance for glory!

'A proof of the attention which is now given to these is supplied by the fact that the most abstract theories have been under discussion, and even such as the satisfactory determination of which would, as their only consequence, have brought about a scientific triumph! Known to every one is the marked fixity with which the root tends towards the centre of the earth, and the stem towards the zenitha constancy which was made the more manifest by the experiments of Duhamel and Dutrochet. Well then, the attempt has been made to gain an explanation of this, Astrue supposing that it was due to an accumulation of sap; Dodar believing that the sun attracted the stem, and the earth the roots; La Hire imagining that the roots direct themselves to the centre of the earth, dragged down by the weight of the nutritious sap, which is reduced to a state of vapour in the stem, through the effect of the elaboration of the plant; Darwin attributing it to humidity; and Knight 
making the action of gravity to come into play. If they have not yet resolved the question satisfactorily-if there be still awanting the theory which will account for the same force of gravitation causing the root and the stem to take opposite directions-the various conjectures matifest at least the power of the human mind, and they are all of them deserving of commendation.

'More important, doubtless, it would have been to have been able to determine whether vegetables possess the property of selecting the nourishment which suits them, and refusing what would be noxious; or whether, on the contrary, they absorb all indiscriminately. And great advances in the somewhat complicated art of cultivation would have been made if we had been able to discover whether vegetables excrete at the extremity of their rootlets, and what it is which they excrete. Although it is nearly a century since Brugman stabmitted to botanists his views on this last point, and althongh Macaire, Cbatin, Meyen, Garrean, Branwis, Goldman, Sachs, Unger, Walser, and others, have studied the matter judicionsly and carefully, we only know after all that the Rotation of Crops of De-Candolle has no certaiu basis to stand upon, having heen followed because it was expounded by so illustrious a master-as genius, like the sun, blinds its satellites, and leads them blindly to follow on, without subjecting their procedure to reason.

'Another problem, however, anil that one more difficult to solve, is to determine clearly whether plants have feeling. In presence of the phenomena presented by curious morements, and special atcitudes, it is customary to say that these are causel by the irritability of the tissues, but never by sensibility, which is generally repudiated as an ausurd hypothesis; but, bear with me if I ask: Where does sensibility terminate, and irritability begin? What are the limits which separate them? It is an old trick of man to try to cheat himself by the employment of words which do not express ideas explicitly. We may feel assured 
that it is not known in any determinate manner why the name has been given to what is called The sleep of plants (The Somnus Plantarum of Linaeus), and what difference of constitution occasions this phenomenon so pronounced in some, and imperceptible or awanting in others. When the sun declines below the horizon, and the long twilight comes on, it may be observed that the leaves of certain species of plants, as those of the Cassia floribunda, turn their leaflets in such a way that they approximate one another considerably, a movement which is generally manifested by the acacias, which are extensively cultivated in our gardens as an oruamental tiee: Ani who has not heard of the sensitive plant, Mimosa pudica L., whose movements, like the natural and periolic ones of sleep, are originated so easily by a passing cloud obscuring for a time the light of the sun, or the distant galloping of a horse, or by the excitation which an insect produces by alighting on the Jeares? Who is not aware that it is enough to touch the extremity of one of its leaflets, in order that all the leaves, and even a b anch, close up as if frightened by the imprudent mortal who has taken the liberty to come near it?

'Remarkable also are the movements of the Hedysarum girans L. (Desmodium girans D.C.), a curious p'ant, discovered in Bengal by Lady Monsen, in which a large odd leaflet is in constant motion; and the other two, a good deal less in size, $k \in e p$ up a lively oscillation of a peculiar kind, on which the vertex, or extremity, of each describes an elipsis - the plane of which is oblique to the axis of the leaf. And we may lastly cite the Dionce $\iota$ Muscipula $L$. (the Venus Trap-fly), which, together with the Drosera.to the Saracenia, anc the $N$ epanthus, has by its movements given rise to a lengthened controversy, in which Darwin, Hooker, Reess, and Will, have displayed their genius and vast experience, as they have discussed with all earnestness the fact whether they be carnivorous plants or not.

'In 1866, Ligersan and Divers having made curious experiments on the sensitive plant, found a remarkable 
relation between the movements of this plant, and the nervous system of man, and believed the influence to be in its origin of the nature of magnetism. Ligersan experienced a painful impression, produced or communicated apparently by this plant, it being observed that its contractions were more rapid and persistent through coutact with an organic body than through contact with a mineral.

'To bring to a close these unconnected statements,imperfect expressions of uncounected ideas, it is but right that we should give place to the immortal Gœthe, poet and naturalist, and author of the theory of Morphology, which is now almost universally accepted. He sings one of his beautiful compositions in memory of Schiller, ylorious son of Germany, and says eloquently: "The coloured leaf feels the divine hand, and contracts on being touched; its slender forms enfold themselves, and find themselves destined to embrace; they appear in graceful pairs re-united around the sacreil altar. Hymen covers them with his wings; and with the diffused precious aromatic perfumes they are deliciously inebriated; and then they develope in seed the numerous germs which the ovaries enclose.

" "Thus uniting themselves as a new link to that which went before, the mysterious chain is carried across our times, and the type is preserved as well as the individual.

" "T'urn now, friend, never to be forgotten, thy gaze to the whirlwind which is agitating all around thee, and to thy spirit there will be nought of cunfusion : every plant will speak to thee its eternal laws; every Hower will speak to thee in language more explicit; and if thun knowest how to read in them the thoughts of the gods, thou shalt know how to comprehend them in all their parts, and under whatever form they present themselves - the same in the hydra, which turus round embracing itself, as in the butterfly which disports itself in the sunshine, and in man, who artificially distigures his true physiognomy."

A second paper, by Senor Alvarez, in this department of 
study-Applied Botany - written more in the severe style of the scientist in dealing with the data and scientific deductions of inductive science, than in that which befits the expression of emotions called forth by the contemplation of discerned truth, is one entitled Causis de lu Ascension de la Savia, or sap, hased on the able works of Dr Boehm.

Another paper by Senor Alvarez which I may cite in illustration of the character of the studies in research pursued in this department of forest science in the School of Forestry in the Escurial, and of the kind of publications to which students may have access in the prosecution of their studies, is one entitled Temperatur del Arbor, 'Temperature of the tree. The following translations of excerpts from this will, I think, better indicate the character of it than would any summary I could give of its contents. In introducing his subject the author writes :-

'Amongst the repeated experiments which have been made on the temperature of trees, those made by Boehm and Breitenlohner, which we are about to bring under consideration, deserve special attention.*

'Krutzsch, professor in the Forest Institute of Tharand, published observations made by him during the years 1852 and 1853, + and Becquerel has published in a series of dissertations his experience, the principal object of which was to determine the thermometric or climatic influence of the forest. + In the meteorologico-forestal observations of Bavaria and Switzerland, the internal temperature of trees has also been the subject of observation; but up to this time there has only been published a resume of the data obtained during the first years.\$

'From these and other experiments, it appears that the periodical and irregular changes of temperature influence differently different parts of the tree, from the roots to the branches. The atmosphere and the soil are two factors

* V. Band LXX. Der Sitz. der K. Akad. d. Wissensch., 1. Abth. Mai Heft.

† Untersuchungen ueber die Temperatur der Bateme, etc., 1854.

+ Mémoires de L'A cademie des Siciences, 1861-64.

\& Zeitschrift der Usterreichischen Gesellschaft fuer Msteorulogie, Band IV. 
which almost exclusively determine the temperature of the tree, both in its ærial and its subterranean parts. The influence of the temperature of the soil extends from the roots to the trunk, but only to a certain height, which is determined by the temperature of the air which surrounds the tree.

'The temperature of the ronts is imparted by the soil. The origin and nature of the soil and the subsoil, its mechanical and physical properties, the degree of humidity, the absence or presence of subterranean water, the superficial covering of the ground, and the varying degrees of sunshine and shade, are so many other factors which influeuce that by modifying the character and degree of temperature imparted to the roots. With change of temperature in the soil, which in most kinds of land are very slight even in the warm days of summer at a depth of one metre from the surface, the temperature of roots must change in the same proportion. The portion of these rocts situated inore than a metre in depth will only be affected by the heat of the ground throughout the year, which varies very little; while the roots at a less depth experience the daily changes of temperature in the superficial layers. A long, large, deeply-penetrating taproot will produce in the warm months a diminutiou, and in the cold months an incsease, in the temperature of the superior roots. Humidity exercises a very great influence on the thermometric conaitions of the soil and roots. From this it may be inferred that the influence of the heat of the soil is not confined to the roots, but through the ascending sap makes itself to be felt to a certain height in the trunk. To determine by experiment this hypothesis, Hartig made some observations on two oaks of the same magnitude and same age, 200 years. At the height of a metre from the ground, he introduced thermometers to three different depths, and noted the thermometric condition of both trunks during the winter's lethargy, as well as during the season of active vegetation. - The aerial parts of a tree are exposed to the direct 
action of the temperature of the air, and to the occasional sunshine, so that the degree to which it is heated or cooled down, depends, when the conditions are the same, on the degree and duration of the sunshine or the shade. And in this respect the trees which are in a clump are differently affected from those which are isolated. The rapidity with which, other things being equal, the mass of a tree becomes warmed, depends on the surface and thickness of the bark, and on the conducting power of the roots and the wood in regard to heat. Wood in general is a bad conductor of heat, but all species are not alike in this respect. The influence of the specific heat of the bark and wood, as well as the chemico-physiological functions of the tree, however, we sball not here take into account.

'Differences in the size and diameter of the tree produce differences in its temperature. The daily oscillations and the maximum temperature of the trunk are so much the greater as the diameter of the truuk is less or as the point of examination is nearer to the surface. The thermometer shows a higher temperature in the branches than in the trunk; and so much is it so as to show the temperature indicated by thermometers introduced into the trunk branch and branchlet to be in inverse proportion to the respective diameters of these.

'From this, then, it is deduced that the internal temperature of a tree takes a character related to and is produced by a great many circumstances having a reaction upon one another. It is therefore necessary, in order to similar observations being comparable together, thai they should be made under identical conditions, and exact accordance in the location of the thermometers, in the height and depth of their position, the diameter of the trunk at the point at which the temperature is observed, and finally in the measure of sunshine or shade.

'All of these particulars serve as a basis to determine at three different heights the influence which the cooling effect of the roots and the crown of the tree exercises on 
the temperature of the same. In experimenting, the cooling effects proceeding from the roots is produced by abundantly watering the ground; and that of the crown of the tree by suspended apparatus acting as a coveriug or shade. To ascertain with exactitude the cooling effect thus produced, it is required to have two trees, one of which may serve as a subject of experiment, and the other, under natural conditions, to serve as a tree for verification or comparison of results obtained.

'To find two trees of the same species, development, girth, and height, and equally exposed to the action of light, presents some difficulty. Others also presented themselves to Boehm and Breitenlohner, arising from the necessity there was that there should be within a certain distance abundant water, and that the tree used for verification should not be so remote from the subject of experiment as to render impossible the comparison of conditions.

'Two birches were chosen, which, however, did not fulfil all the conditions, as they were not in every respect exactly alike. The tree selected for experiments was in every respect weaker than the other which was to serve for comparison. In three different ways could be carried out the idea of placing thermometers, one at the foot of the trce, auother half-way up the trunk, and the third in the branches-viz., first, placing them vertically equidistant without regard to the diameter of trunk or branches; secoud, without regard to equality of vertical distances, to seek for equal diameters; third, without regard to diameters, to place the thermometers at equal distances, and at equal depths in the trees. It was necessary to avoid a mixing of these three methods, in order not to complicate and confuse the observations.

"Through the central layers of the birch constituting soft wood through which circulates the sap, it presents a possibility of placing the thermometer in the medulla of the tree. By adopting the first of the methods spectied, the depth at which the thermometers would have been 
placed in corresponding points in the two trees would bave been very different; and by adopting the second, the distances of the points of observation would have been rather great, especially in the lower pirt of the trunk. The principal object to be attended to, was the determining the influence of the temperature of the soil on the thermometric condition of the trunk in relation with the ascending movement of the sap. Taking as a fundamental fact that the temperature of the soil influences the internal temperature of the trunk the more, the less distant the p int is from the ground, and the younger are the wood circles, the experiments ought to be male at equal distances from the ground. In the first case, the temperature of the tree is intimately connected with the volume of the trunk or branches, and with variations in the themometric conditions of the air. And the effects of temperature of this and of the sunshine propagate themselves transversely, while the temperature of the ground is propagated from below upwaris. The direct comparison of the temperatures of the trees in the tirs, two cases being excluded, this determined the naturalists Boehm and Breitenlohner to adopt the third method possible, that is, equal heights and equal depths. The two birch trees selected presented the following measurements :-

Horizontal distance between the two trees,

Height of birch experimented on,

Height of birch of verification or comparison,

Distance of lowest point of observation from ground,

Distance of middle point trom lowest.

Distance of highest point from middle one,

55 metres.

$15 \cdot 5$,

12,

$6 \cdot 3$,"

$6 "$

6 ", 

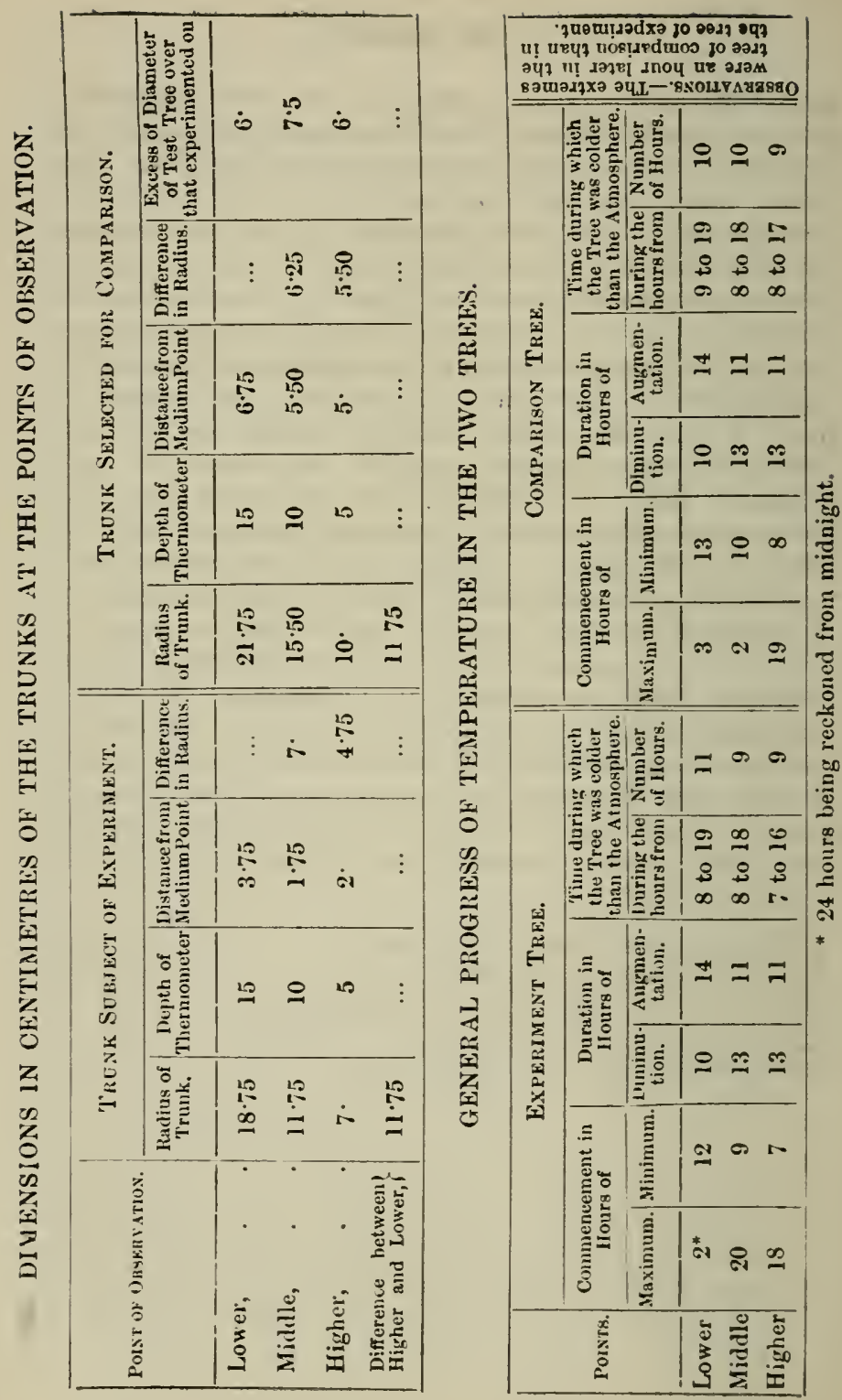
The tables on the preceding page are tabulated results obtained, omitting remarks male ou each, and on many of the details of each,

Temperature [probably Centigrade] of the air around the trees. Averages of fifteen daily observations from 21 st August to 10th September:-

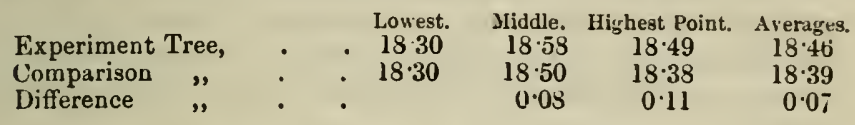

Temperature of the trees from 21st August to 10th September. Average of fifteen daily observations:-

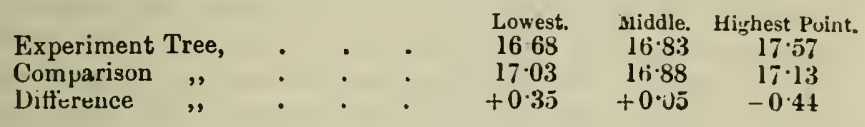

Thermometric difference between the air and the tree:-

$\begin{array}{lllllll}\text { Experiment Tree, } & \text { Lowest. } & \text { Middle. } & \text { Highest Point. } \\ \text { Comparison } "-1.62 & -172 & -0.92 \\ -1.27 & -1.62 & -1.25\end{array}$

In a comparison of the tivo trees, it is seen that the comparison birch is in its lower part as much hotter, as in its upper part it is as much cooler than the tree which was the subject of experiment. The higher temperature of the lower part of the former is attributable to the greater accumulation of heat in its greater volume; and on the other hand, that in the upper part is smaller tbrough the greater diamater retarding the occurrence of the extremes.'

There has been published also by Senor Alvarez another paper entitled Transpiracion de las Plantas-Transpiration of Plants-a paper based on the works of M. J. Dufour, and on a memoir, Ueber das steigen des Transpiracion stromes bei holzplanzen, published in the Arbeiten des Botanishen Instituts in Wurzbourg III. Heft I.; and another entitled Formacion de los Nitratos en las Plantas. 
It may be long before Botany takes a place among the so-called exact sciences, but much was done to impart to the studies prosecuted under the designation of Applied Botany somewhat of the character of these. In 1877 there was published by El Illmo. Senor D. Maximo Laguna, one of the fathers of the School of Forestry, of whom mention has been made, an inaugural discourse, delivered by him before the Royal Academy of Science in Madrid-Discurso leido ante la Real Academia de Sciencas Exartes, Fisicas, y Naturales, por El Ilmo. Senor D. Maximo Lrtgunu, en su Reception Publica.

Some years since, by Royal order, a commission was given to this distinguished naturalist, as InspectorGeneral of of the Corps of Forest Engineers, and others to be associated with him, to prepare a report of the forest flora of Spain. In 1883 the first part of their report was printed at the expense $\mathrm{cf}$ the Government. It comprises a description of the trees, shrubs, and bushes, indiggenous or naturalized, in Spain, with short notes and observations on the culture and economic uses of the more important. There are given the most generally-used systematic names; the popular numes; references to plates besides those accompanying the report which have been examined; a detailed deseription of each plant; the areas throughout which they are found; the locality in Spain in which each is found; conditions of the locality in which it flourishes; and brief remarks or its culture and exploitation. And it was intimated that probably there would afterwards be issued as an appendix to this work, a description of the trees and shrubs most frequently cultivated in Spain; but that this would be strictly a flora, and not a treatise on sylviculture, nor on exploitation or forest management ; there would be given, however, some indications of the products and the culture of the more important.

In the following year there were issued, at the expense of the Government, 1000 copies of 38 plates, executed in chromo-lithograph, illustrative of the first part of the report of the commission. Every precaution necessary was taken 
to secure a perfect re-production of the drawings which had beeu prepared; and the work has been beautifully executed, representing the leafage, flowers, and fruit, with the organs delicately drawn and exquisitely coloured, having been completed under the charge of Senor Don Justo de Salinas, by whom the drawings were prepared.

While this work was in progress, there was published by Sr. Laguna a pamphlet, entitled Coniferas y Amentaceas Espanolos -Spanish Coniferæ and Amentaceæ. In the preface to this he intimates that the Forest-Flora Commission had presented to the Minister of State a report in manuscript, illustrated by drawings, of their work in regard to conifers and amentuaceæ, in which details were given of some species of special interest to forest engineers engaged in sylviculture; but not knowing what time might elapse ere this should be published, be considered it might be of use to some meanwhile in classifying species belonging to these groups. the principal ones of Spanish trees, to have this key, which was arranged dichotomously. The portion relating to Conifers had been published in $\mathbf{1 8 7 4}$ in the Revista Forestal, Economica y Agricola, vol. viI., and with some corrections and additions made to it it was added now to a like key to the Amentaceæ

In 1870 and in 1872 had been published Résumés, the former of the work done by the Commission in the years 1867 and 1868; the latter of this done in the years 1869 and 1870.

In 1880 there was published by the same author, a paper read at a Conference on Agriculture, held in the Conservatorio de Artes in Madrid on the 11th April in that year, entitled Plantas Cryptogamas, su importancia en la AgriculturaCrytogamic plants, and the importance of them in connection with agriculture. In the following year was published by him another monograph, Un Mesto Italiano y varios Mestos Espannolas - An Italian Oak, and sundry Spanish Oaks; and in 1884 a paper entitled Caracteres 
de la Flora Espannola-Characters of the Spanish Flora. A paper read at a Conference held in the Athenæun, Madrid, on the 11th March in that year.

And in the Revista de Montes, or Forestry Review, for January, 1881, appeared the first of a series of papers by lim on Cypress-like plants, their habits and their homes.

Thus has been made, and is being made, provision for aid in the prosecution by students in the School of Forestry, of the studies in Applied Botany.

Of the ferns from the Philippine Islands in the Museum, there is a descriptive catalogue by Senor Laguna; and by the same author a description of an oak found only in these Islands. There is a memoir on the productious of the forests of the Philippine Islands, by Senor D. Ramou Jordana y Morera, Chief of the first-class of the Corps of Forest Engineers; and in 1885 was published a large volume by the same author, Bosquetjo Geografico e HistoricoNatural des Archipielago Filipino-A Geographical and Natural History Sketch of the Philippiue Archepelagowith additional notices of the productions of the forests, of which for many years he had been inspector; and a systematically arranged catalogue of the lignous forest and cultivated plants, collected in the forests of Manilla by Forest Engineer D. Sebastian Vidal y Soler, with notices of localities in which each had been found-a work of merit; and thus are the students supplied with works of reference in regard to all the forest products of the Philippines stored in the museum of the school.

\section{Sub-Section 4.-Sylviculture.}

Sylviculture on the Continent corresponds to arboriculture in Britain. The difference is mainly this: the former regards the wood or furest as the object with which it has to deal; the latter looks to the trees individually, whether growing solitary or in a mass of greater or less extent, as the subject of its consideration. There is more in this difference than may at first be supposed; but it may be 
that the difference in the treatment of woods and forests in the countries in which these terms respectively are used, is in a great measure the result or consequence of the new departure taken by forest economy within the present century ; and many of the treatises on subjects connected with sylviculture, published in Spain, are not greatly dissimilar to works which have been published in Britain on arboriculture.

In 1842 there was published by D. Pablo Bentelou,Director of the Royal Gardens of Alcazar, Memoriae, \&c., a Memoir on the Acclimitisation of Foreign Plants, treating of climatic transplantation and acclimitisation; with a list of foreign plants suitable, in the opinion of the author for introduction into Spain, stating their habitat and properties.

In 1845 was published D. Josè Maria Pamāgua, Professor Emeritus of Agriculture, and member of sereral scientific societies, Manuel del Podador, \&c.-The Pruner's Manual, or directions for the treatment of forest trees, in forests, woods, or plantations-in which physiolugical phenomena, tbe knowledge of which is necessary to the intelligent practice of pruning, are detailed; and the operation is described in its application in different ways, and to a great many different kinds of trees-being a compilation from various French authors, and instruments employed; with notices of the appropriate seasons of the year for such operations.

In 1844 was published in Madrid El Arbolista Practico, treating of the art of cultivating all kinds of trees; of the preparation and division of each ; of the multiplication of them; of diseases from which they suffer; and of insects injurious to them; with a description of all kinds of forest and garden trees; the culture which each requires; its properties and uses. It is a manual, one of a series published about that time, under the collective title of Agricultura Popular. The directions are compiled from the most distinguished writers of the day. 
In 1862 was published a work entitled Calendario del Agricultor and Ganadero Para, 1862, \&.c.-Almanack of Agriculture and Pastoral Husbandry-by D. Dominga de la Vega y Ortis, illustrated by 17 engravings, and a beautiful agricultural map of Spain and Portugal. It contains, amougst otber things, an article entitled Arboles de Ribera-Trees of the Coast-divided into three parts, which treat of the importance and usefulness of these; of the storing of the water, and the amelioration of the climate; and of the utilisation and equalisation thronghout the year of the flow of rivers and running streams. And in all, much is said of the utility of extendiug the woodlands as a means of iucreasing the salubrity of the country, or diminishing the duration, frequency, and intensity of droughts: of ensuring the perennial flow of rivers by increasing lignous productions, and by other appliances of importance; and information is elsewhere supplied in regard to the proper treatment of timber. The article of which mention has been made was re-produced in the Gacefa de Madrid of the 29th October, of the year of its publication, 1862.

In 1863 was published a volıme entitled Manual de Selvicultura Practic , or a Manual for the forester, the gardener the proprietor, and the forest warder, by D. Josè Garcia Sanz. It treats of sowing, planting, pruning, and all that concerns the cultivation of various kinds of forest trees ; the collecting of their seeds, the diseases from which they suffer, \&c. And in the following year another, entitled Manual del Aaricultor Asturiano, by D. Luis Guez, of the Faculty of Science, Professor of Natural History, and member of the Patriotic Economical Society of Oviedo. It treats of the cultivation of the beech, the oak, the chesnut, the walnut, the piue, the ash tree, and others.

In the same year, $18(14$, was published Arboricultura os a rultivo de Arloles y Arbustos-a large work, in two volumes $8 v o$, with numerous plates. 'They' were lectures delivered at the Scientific and Literary A thenæum of Madrid, by D. Antonio Blanco Fernandez, Professor in the Institution, 
Doctor in Medicine and Surgery, Professor of Special Cultures in the Central High School of Agricultural Engineers, and member of various scientific societies at home aud abrcad. It treats of the organs, the physiology, the influence of atmospheric agencies, and the longevity and death of trees; it enters then on the consideration of all that relates to the culture of trees, and to the greatest possible extension of woodlands, with a view to aiding in which there is given a monograph on the culture required by each species; with notices of what is required in this iu gardens, in pasture lands, in the open country, in parks, \&c.; and the work concludes with observations on the utilisation and profitable exploitation of woodlands ; and a recapitulation of the Spanish forestal legislation, which might affect or interest proprietors. The author states that he has throughout these lectures made use of the doctriues advanced in the work on the same subject by M. Du Breuil.

In $187+$ was published in Tarragona, under the leading title of Estudios Forestales - two volumes by D. H. Ruis Amado, Forest Engineer, treating of the forests in their relation to the uecessities of the village population. The author held the rank of Forest Engiveer-in-Chief of the first class In this are discussed numerous matters pertaining to forestry. The work was held in high estimation, as was also the author, to whom was awarded a gold medal for its publication.

Interested as the authors of these several works were as professional men, in the professional work to which they were more immediately called, they saw, as enlightened patriots, that by them, if not also by all who engaged in a similar calling, the importance of replenishing divested forests, and creating an extension of the woodlands of the country, was being realised, as it had not yet been realised, by the mass of their countrymen. 


\section{Section 4.-Studies of Fourth Year.}

In the fourth year of the student's curriculum, be is required to give attention to xilometry ; forest ordenacion, or forest partition and systematic exploitation on scientific principles; forest industries; the administration of law; and political economy.

Sylviculture, to which attention is given in the third year of the course of study, and xilometry and forest ordenacion, to which attention is given in the fourth year of that curriculum, all relate to the modern scientific exploitation of forests, which, devised and developed by Hartig and Cotta in Saxony, in the beginuing of the present century, has been introduced into Spain as into the other countries on the Continent of Europe, giving a character to the whole course of procedure in regard to forests, and the training of forest officials for the management of these.

\section{Sub-Section 1.--Xilometry and F'orest Ordenacion.}

Xilometry comprises all that relates to the measuring of wood, and the principles involved in the application of this to trunks, boughs, and branches of growing trees, in order to enable the administrator of a forest to ascertain what cubic increase is being made by growth in each year, or decade, in the trees of a forest under his administrationthat he may proportion to this the quantity of timber or firewood which may be taken from different compartments in it, it may be in different stages of growth and with varying degrees of vegetative vitality, with a view to insuring sustained productiveness. Ordenacion relates to the partitioning of the forest into compartments; with a view to successive thinnings of different extent, culminating in a final felling, which will leave only the trees reserved for seeding to ensure the natural re-production of the forest. And Sylviculture relates to the culture of seedlings, saplings, 
poles, and perches; the production of these by self-sown seeds; and artificial sowings or plantings required in the extension or creation of forests, or the replenishing of any which have become to a greater or less extent devastated, and of spots in self-sown re-produced forests, which from any cause may not have been covered with seedlings like the ground around; and to the treatment of the whole, till the cycle or revolution of re-production and felling has been completed.

In the conservation, culture, and exploitation, or profitable disposal, of forest products, considerable differences of practice exist. In Britain we hear much of gamekeepers; on the Continent of Europe we hear much of forest-warders; here the game, there the wood, is the object of conservation. In Britain we hear much of arboriculture; on the Continent we hear much of svlviculture: the former term $I$ have told refers to woods and plantations, the other term to woods and forests; in the one case the unit is the tree, and the wood is considered as the collection of trees; iu the other the wood is the unit, and the trees are considered only as its constituent parts. In the former, attention is given primarily to the sowing and planting, and pruning it may be, and general culture of the tree: nowhere, perbaps, has this arboriculture been carried nearer to perfection than it has been in Britain; and the effects produced by the resulting woods are wonderful. In the latter, attention is given primarily to the wood or forest as a whole, capable of yielding products which can be profitably utilized; and the result generally is 1.0 produce a much greater proportion of fine trees thall does even the arboriculture which has been referred to. And not less different is the exploitation of woods in Britain and ou the Continent. In Britain the pecuniary returns obtained from woods is considered a secondary matter in comparison with the amenity and shelter which they afford; but on the Continent the material or pecuniary product is made the object of primary importance. 
The arboriculture of Britain may seem to leave little to be desired; but nowhere, perhaps, are forests treated with greater recklessness than they liave been in some of our colonies and dependencies. In India, however, and in some of our colonies, an endeavour is now being made to arrest the destructive practices which have prevailed, and to introduce a system of treatment of forests more in accordance with the advanced forese science of the day.

In the United States of America, and in Canada, there have been effected extensive clearings of forest lands, resulting in injurious effects upon the climate, and in a greatly diminished supply of timber, with no prospect of this being compensated by the subsequent growth of trees in the localities. And in some of our colonies extensive forests have been treated like beds of onions, leeks, cubbages, and turnips, in the kitchen garden. Trees deemed suitable for some purpose desired have been felled, others around them have been left standing, or have been cut down to allow of the felled timber being brought out; and the results have been scarcely less destructive than the forest clearings elsewhere. These results may be seen in what were once forest-lands in the colony of the Cape of Good Hope.

More than 200 years ago France was in danger of being entirely devastated by this system of jardinnge in the exploitation of forests, and in 1669 there was issued an ordinance-which soon became extensively famous, and is famous still-requiring the forests to be divided into a specified number of sections, one only of which should be exploited at a time, so as to allow time for the trees to be reproduced in each before all the others had been exploited in succession. The measure was not new, but was one likely; where adopted, to save not only France, but also other countries in Europe from devastation. Less than 150 years sufficed to show that this was a vain hope, for the reproduced forests were not equal to those which had been felled. And early in the present century there was devised, in Saxony, a more complicated, 
but a much more efficient method of exploitation, which is being adopted everywhere on the Continent of Europe. It has been introduced with most satisfactory results into the management of forests in India ; and the adoption of it seems to be the only means available to prevent the ruin of forests in our colonies, which are now being rapidly destroyed.

In this also the forest is divided into a number of sectious corresponding to the time required for the reproduction of the trees. But instead of exploitation being confined to one of these at a time, the supply of wond required is obtained from the felling of the trees in one or more lots, and from first, second, and third thinnings in others-all being so arranged as to secure simultaneously, and without prejudice to one or other of them, an improved condition of the forest, a sustained supply of products, and a natural reproduction of the felled forests by self-sown seed. And all these results are now being obtained by this method of exploitation. This may seem to be the ne plus ultra of forest management. But in its application to any forest the arrangement of details must be based on the knowledge of a number - of a great number-of facts in regard to that forest, and an ordenacion or arrangement of sections and divisions of the forest founded on these.

There was published in 1847 a resumé of a treatise on forest taxation by M. Noirot-Bonnet, which had been published in France. It is a brochure of 129 pages quarto,entited Manual de la I'asacion de montes y bosquet, por Don José Maria. Aniugua. It comprises eight chapters, under which respectively the author treats of:-1. The taxation of woods, witb different tables for use in the valuation of them under different aspects. 2. Tables of cubic measurement. 3. The increase in cubic measurement of trees. 4. The taxation of different species, with regard to various systems of exploitations. 5. Of the general possible production relatively to area and volume. 6. The comparative quantity of material products. 7 . The pecuniary return obtainable by these. 8 . The produce, brought under exploitation by thinnings and successive fellings. 
From the use made in English of the word tax, and its derivatives, which in popular discourse, if not also in scientific discussions, are applied to what is exacted by the State directly or indirectly from members of the community, some difficulty may be experienced in receiving it as it is used in connection with forest economy on the Continent, in which the term taxation is applied to the determination of what produce a forest may yield, without injury to itself and with advantage to all concerned. Taxation, or the determination of this is a necessary operation in the profitable and scientific exploitation of a forest. It follows the survey and preparation of an inventory, aud the presentation of a report on the conditions as to the growth and the vigour of vegetation of a forest. It has for its object to ascertain the quantity of wood material contained in a separate portion, or in an entire wood, and to determine the laws of its increase.

By Professor D. Francisco de P. Arrillega, member of the Corps of Forest Engineers, and Professor in the School of Forestry, it was seen that to facilitate important studies there was required a text book of formulas and tables required in the valuation of forests. Such a work was published by Dr. Gustav Heyer, Director of the School of Forestry in Munden, a man deservedly held in high estimation throughout Germany, and amongst students of forest science in other lands. This Senor Arrillaga translated into Spanish, and in 1872 it was printed by the Government at the National Press, under the title Compendio de Valorucion de Montes. According to the definition of Dr. Heyer the valuation of forests is that department of Dasocracia or forest ecunomy, which has for its object the determination of :- -1 . The value of the ground by itself. 2. The value of the entire vegetable covering of this. 3 . The value of the forest trees, and arborescent productions. 4. The annual reut or revenue of the ground, of the vegetable cuvering, and of the forest. The designation forest being now applied to the ground, and the vegetable covering and the trees growing upun it conjointly. And in 
his work he treats:-1. Of general principles comprising the knowledge of the mathematical, economic, and forestal principles affecting the determination of the value of forests; and thereafter of the special application of these to the valuation of a forest. Under the first of these heads he discusses in successive chapters-1. The subject of value, distinguishing between price and intriusic value. 2. The idea of interest, discussing differences existiug in the amount of interest in general; differences affecting forestal interest in particular; and the determination of interest in relation to forest property. 3. The calculation of interest according to a critical determination of the kind of interest, simple, compound, or combined, which should be selected in the capitalisation of revenue or rent; a critical determination of simple interest of compound interest; and of a combination of these. 4. Formulæ for the calculation of interest, according to necessary modifica tions of conıpound interest, with tables of factors to be made use of in such calculations. 5. Income and expenditure.

Under the head of special application of the general principles to the valuation of a particular forest, he discusses in successive chapters :-1. The determination of the value of the ground by its abstract value, its cost, and the price which would be obtained by sale, with a statement of some general considerations affecting the abstract value, and a critical determination or decision relative to the employment of this in determining the value of a forest. 2. The determination of the value of the vegetable covering according as this may relate to the whole plot, or to isolated trees, or to a specified portion of the lot, discussing in regard to the first mentioned case the determination of the abstract value of this, and conditions which may effect this advantageously or otherwise; the determination of it by the cost, and general conditions on which the amount of this depends; and the determination of it by the price which would he realised by sale. Thereafter are discussed the 
valuation of the increase by growth of the vegetable covering in one or more years; and the valuation of the vegetable covering of a whole forest, in the condition of a formal series of compartments in successive stages of growth, and preparation for thinning and felling. 3. Valuation of a forest, comprising both ground and crop by its abstract value, its cost, and the price it would bring if sold-viz., with a valuation of its returns or rent. 4. Determination of forest returns or rent-that of the ground; that of the crop; and that of the forest comprising both. Anl there are appended tables for the calculation of interest on the bases of different factors.

In 1880 was published a volume entitled Elementos de Tasacion Forestal por el Ingeniero Cav. Francisco Piccioli, Director de la Real E'scuela de Montes de Valumbrosa T'raduri - dos del Italiano por R. Alvarez Seriex Alumno de la Escueln. Especial de Ingenieros de Montes, Elements of Forestal Taxation by the Cavalier Francisco Piccioli, Forest Engineer and Director of the Royal School of Forestry at Villambrosa, translated from the Italian by $R$. Alvarez Seriex, eleve of the School of Forest Engineers, Alumnus.

The two parts of this work by Cav. Piccioli, remarks Senor Alvarez, though intimately connected are yet severally complete, and both manifest similarly excellencies of lucidity in arrangement, and a free style in strictest harmony with mathematical precision. In the flowing language of Ariostu, and others of his country's literary men, he describes the implements, and the mode of using them in collecting the data required, and the application afterwa:ds made of the data obtained.

The Iaxation relates to the determination of the material at the command of the engineer; the Assessment has to do with the determination of what may be utilised. As stated, it is the first part only of the Cavalier Piccioli's work which is bruught under consideration. 'The fundamental data required tor taxation are measurements of the trees, of each and all, or of a number of thom so selected as to 
suffice the operator in ascertaining, with proximate accuracy, sucl average measurements as will afford satisfactory data for estimating the measurements of the remainder.

In the work under consideration the first chapter is devoted to a description of the structure and application of dendrometric instruments; and under successive headings are described: -1 . Instruments for the measurement of circumferences and diameters. 2. Means of determining heights of trees. 3. Various dendrometers. 4 Trigonometrical measurements of heights and diameters. 5 . Instruments for measuring the increase made by growth. i. Instruments employed in the measuring of timber, and in determining the power of resistance and density of woods.

The second chapter relates to instruments employed in determining the measurements and the increase by grow th of single trees; and under successive headings are clescribed :1. '1'he typical measurements made. 2. 'The determination of the cubic measurement of single bolls. 3. The determination of the cubic measurement of a standing tree. 4. The determination of the cubic measurements of stump, branches, and bark. 5. The determination of the increase made by growth.

The third chapter is occupied with discussions relative to trees, and the increase made by them in woods. Under successive headings are discussed:1. The density of the growth of trees in a forest, and curresponding classifications of them on this ground. 2. The determination of the number of trees in a forest by different methods - enumeration and otherwise; the formation of classes, according to height and bulk; the selection of the number of typical trees for each class, concluding with observations and formulas relative to the selection of type trees. 3. The increase made by growth, and the determination of periods in which this varies by increase or diminution. 4. The construction of tables, including the calculation of co-efficients, and methods of 
determining approximately the increase made. 5. The determination of the produce of clearings.

In 1883 there was published a valuable exhaustive treatise on the scientific classification, arrangement, and exploitation of forests, entitled Ordenacion y Valoracion de Montes, by D Lucas de Olabazal, of the Corps of Forest Engineers. In this are embodied and assimilated the instructions given otherwise in regard to the mensuration of trees, to the determination, by estimate or otherwise, of the cubic measurement of the contents of a clump of trees, a wood, a compartment, or a forest ; to the determination of what increase by growth is being made, or which is expected to be made; and to the valuation of forests and forest lands: the whole being suborlinated to the purpose for which these data are required-the management and exploitation of forests in accordance with the advanced forest science of the day. In doing this the author defines a forest as ground of considerable extent. covered with woods of spontaneous growth or artificial planting, maintained specially witls a view to obtaining timber or wood, or with a view to prevent damages being done by denudation. He recognises the difference between what he designates herbaceous forests, and timber forests and coppice-woods.

In the first part of his work, in which he treats of data required as preliminaries to Ordenacion, he specifies amongst these an inventory or special report in regard to the legal condition of the forest, in regard to the administration of it, and in regard to rights of servitude upon it; its boundaries; its natural conclitions in relation to position; the character of the ground as to composition and superficial contour; and its forestal condition in numerous particulars. Amongst others these : details in regard to the general plan of the forest; the outline, position, contents, and general conditions of the different clumps, woods, or compartments, and the relative value of the characteristics of each of these; with details of a complete and of a 
partitional survey; and a plan or chart of each compartment. The author details then all information embraced in the studies of the school in xilometry: both that relating to the cubic measurement of the wood, and that measurement in regard to all the trees on the ground; and all the information embraced in the studies of the school in regard to increase made by growth. He then treats of secondary products, and of intrinsic conditions of the forest.

Treating in the second part of Ordenacion strictly so-called, he specifies as preliminaries to be determined the formation of circuits; the kind of trees to be grown; the exploitation to be followed-timber forest, coppice, or a combination of the two-and the number of years to be preferred as constituting the revolution or cycle of growth and reproduction. Next, under the head of Methodes de Ordenacion, there are detailed the different methods of division of forests in use-that according to equal areas, or the French Methode a tire et aire; that inversely proportional to the condition of the crop; areas inversely proportional to the actual produce; and what he calls the indirect division. There are next discussed the methods of division followed in Spain; and there is given in detail, with illustrative chart, the plan of Orderacion adopted in the forest 'La Herreria.' 'There are then passed in review the methods of distribution proposed by Bekman, Ostellt, Schilcher, Hennert, Wedel, J. L. Hartig, and E. Cotta. There are next discussed what are designated the rational methods of exploitation, summarised as:-1. Methods based on average increase. 2. Methods based on the Austrian rates. And 3. The harmonic methods. Under the head of Austrian rates, a development of that of Hartig and Cotta, he passes in review the views of Huber, advanced in 1812, and those of Hundeshagen.

Proceeding then to the subject of exploitation the author discusses in succession the preparation of a general plan of operations; the preparation of a special plan for each compartment; and the successive revisions to which this should be submitted as exploitation advances, and new 
data are obtained-all in accordance with what is generally done in other countries in which the forests are thus managed. There follows a chapter on the ordenacion of irregular timber forests; and thereafter discussions of the theory and practice followed in the valuation of forests, with detailed cases in illustration of the satisfactory consolidation of lordship or tenure and territory, in disputed cases involving difficulties.

\section{SeCtion 5.-Forest Industries.}

Under the head of Forest Industries, information is supplied to the students in regard to all that is being done in Spain with forest products to prepare them for the market and for use. It includes the cutting up, if not the felling of timber, excepting in so far as the manner of doing this may affect the use to be made of it; the preparation of fuel yielded by the forest, whether as firewood or as charcoal; the collecting and preparation of bark, and in connection therewith the preparation of cork ; the collecting and manipuiation of resia ; the collecting and disposal of esparto grass; and much besides.

Of the comprehensive chararter of the instruction given under this head, and the provision made to fit forest engineers for the efficient discharge of duties to which they may be called to give their attention, in connection with the profitable disposal of forest production, an illustration is supplied by a volume entitled Industria Forestal-Agricola, published by the illustrious Senor D. Salvador Ceron, Chief of the First Class in the Corps of Forest Engineers, superior Honorary Chief of the Civil Administration, and KnightCommander of the Royal Orders of Charles III. and of Isabel la Catholic, \&c., in which information is supplied in regard to well-nigh a hundred materials and prodncts and processes of forest industry.

In the catalogue of articles of forest produce sent to the Agricultural Exhilition, held in Madrid in 1867, there appear round timber, cut timber, charcoal, resin, bark, \&c, 
Sub-Section 1.-Preparation of Timber, Firewood, and Charcoal.

In 1877 there was published by Senor D. Eugénio Pla y Rave, Marcos de Maderas, \&e., or Felled Timber for use in Civil and Naval Structures, with the prices obtained for them, and other forest products in the different provinces of Spain.

After classifying the timber referred to as timber used in shipbuilding, in architecture and engineering, in carpentry and cabinet-making, and as round logs, logs partially squared, square logs, and sawn timber-and stating what kinds of timber yielded by the forests of Spain are used for the different purposes, and sold in the different forms spoken of, and conditions determining different sizes, and prices of these, he proceeds to give tabulated statements of the linear and cubic measurement of different kinds, the unit of measurement by which each was then sold, and the prices obtained in the different provinces in Spain, in Cuba, in Porto Rica, and the Philippine Islands; also, tariffs settled by Government for direction in the purchase of timber in the arsenals and other public workshops in the kingdom; and in an appendix tabulated statements of corresponding longtitudinal and specificial measurements, weights, measures of capacity, liquid and dry, and designations of quantity used in sales of firewood in the different countries of Europe.

And in the Kevista de Montes, or Forestry Review, of November, 1879, is given the first of a series of papers on the specific gravity and density of woods of different kinds.

For firewood there is in Spain nothing like the demand which there is in Central and Northern Europe. The climate is different, and I saw there no such extensive preparation and storage of this as I had seen elsewhere. For domestic purposes there seemed to be used exclusively small wood, such as might be yielded by branches and brushwood, and charcoal seemed to me to be used by all who could afford to make the purchase of this. 
Information in regard to the preparation of charcoal, aut iu sorne cases in regard to the collecting and utilising of products, resulting from the distillation of wood, is supplied by Senor Ceron; and in 1885 there was published by D. Carlos Castel y Clemente, member of the Corps of Forest Engineers, a volume entitled Combustibles Vegetales: Teuria y Practica de la Combustion, Carbonizacion, y Ilestilacion de la Madera, or wood. For some years it had been felt as a great desideratum in the class of Forestal Industriy in the School of Forestry, a treatise ou this department of forest industry, which, being adapted to the existing conditions of forest production in Spain, and to the possible development of industries in which might he utilised more extensively the forest products of the country, might serve as a text-book for the students, and for auy others who might give their attention to this branch of industry. The collection of data for the preparation of such a work was begun by the author, others communicated to him observations made by them; and the production of this work was the result.

In successive chapters are discussed: -1 . Geueral ideas of combustion; the combustible elements of wood; and the theory of combustion. 2. Firewood, with a definition of tirewood; notices of the calorific power and phenomena of its combustion; directions in regard to the felling of firewood, and the classification and sale of the material. 3. Charcoal ; the nomenclature and classification of different kinds; horizontal and vertical furnaces; qualities and produce of charcoal made in the open air ; relation between the wood burned and the charcoal obtained. 4. Charcoal and tar furnaces constructed for the preparation of tar ; carbonisation in there; different-structures employed. 5. Apparatus for distillation of wood, and process for the procuring of pyrolignous products; apparatus and process employed in the separation of tar, methylene, and icetic acid; apparatus and process for the preparation of illuminating gas from the distillation of wood. 6. Potash, mode of obtaining this, and process of purifying ash salts 
obtained from wood. And in the appendix are discussed the origin and classification of peat or turf ; the composition and analysis of this ; the digging out of peat ; the carbonisation of it, and the products of the distillation.

Sub-Section 2.-Collection and Manipulation of Resin.

Similar to pitch and tar in chemical composition are resin and turpentine. But these can be obtained from growing trees. In the work by Senor Ceron, which I have cited, information is given in regard to the collecting of the raw material, the manipulation of this, and uses to which the products are applied in Spain. This is an industry carried on largely in the plantations, of maritime pine, on the Landes of the Gironde.* The abundant growth of this tree on the Peninsula is confined almost entirely to the western slopes of the west coast of Portugal.

The pine most abundant in Spain is the stone pine Pinus Pinea, there known as the Pino Pinnonero, the Pino de la Tierra, the Pino Doncel, the Pino de Pinnon Comestible; and it is found to be well adapted for profitable exploitation as a resin yielding tree. It abounds in the province of Cadiz, and Senor Ceron gives the account which follows of the exploitation and manipulation of its produce:-It is believed to be indigenous, and produced from seed; it covers extensive areas of sandy soil, and of lands called Barros-alluvial lands-in the lower lying and sub-mountainous regions of that province.

' The resiniferous vessels are not so pronounced in this pine as they are in the PinusPinaster-the cluster pine-and in the Pinus maritima; and the body of the tree is not so impregnated with resin as are these. When the east wind prevails, $t$ and the days are warm, the resin accumulates in great quantities in the incisions made in the

\footnotetext{
* Information in regard to these, and the explcitation of resin produced, I have givell in a volume entitled Pine Plantations on the Sand Wastes of France.

+ I presume the wind is designated from the direction whither it blows, contrary to British practice of desigmating the direction of winds by reference to whence they come.
} 
trees; and the evaporation of the spirit of turpentine is so rapid that the resin solidifies, obstructing thus the flow of additional material. There have not as yet been made the experiments necessary to determine the maximum quantity of resin which the stone pine may yield.'

Senor Ceron having been urged repeatedly to undertake the direction of the resination in the pinery called Villanueva in the Province of Puerto-Real, undertook, but with some reluctance, the task, making 5000 pines of from 30 to 50 years of age the subject of experiment.

'In the latter halt of March, 1872,' say's he, 'they began to bleed the pines. From a decimetre above the ground, to the height of a metre, they cleared the bark of all asperities and roughnesses for a breadth of two centimetres. With a pitchworker's hatchet the first incision in the tree was made, cutting into the trunk from the lower edge of the cleared bark, with a bradth of 11 centimetres, a length of 2 decimetres, and a depth of 1 centimetre.

'To collect the resinous material there was followed the method of M. Hughes, there being used small vessels of clay, glazed inside, in the shape of a truncated cone-like a small flower pot-and about a quarter of a litre in size. At the bottom of the incision there were fixed some iron holdfasts, slightly bent, along which the resin might run, flowing without loss into the receivers. As the incisions are enlarged the receivers must be raised, which is done by their being suspended from a nail by a hole in their side.

'It inay be observed that with this species of pine the receivers require to be renewed every third, or it may be in some cases every fourth day, this depending on the vegetative vigour of the tree and the state of the atmospliere. When, as is frequently the case in summer, the east wind prevails for some time, the evaporation of the spirit of turpentine, and the aqueous constituent with which the resin is combined, evaporate with great rapidity ; the turpentine becomes solidified, and it is thus kept from 
flowing into the receiver, and the resiniferous vessels of the tree become obstructed, the flow of the liquid is arrested. To meet this it is necessary to change the receivers every three days. When the wind is north-west and west the air is cooled, and the turpentine flows till the fourth day without any necessity to change the receivers.

'It has also to be stated, that when the incision penetrates the sixth ring of the alburnum, there are thence obtained only slight indications of turpentine; that from the second and third layers are obtained the largest quantities; that frum the first and fourth there flows less, and still less from the fifth. Amongst the trees chosen for observation those from 35 to 45 years of age yielded proportionately the greatest quantity of turpentine; and of these those which were growing with greatest vigour and luxuriance.

'The collecting of resin was continued till the 15th of October, giviug seven months of a resin harvest, or, as it is designated, resination. Collected conveniently in a receptacle prepared for the purpose, the whole quantity measured $7: 335$ litres, which was equivalent to about $1 \%$ litre per tree. From this, when manipulated in manner and form to be afterwards detailed, there were obtained 368 litres, or 32 arrobas - the arroba is a weight of 2.5 pounds - of boras, or earth, impure resin, mixed with small fragments of clips, bark, \&c., or 5 per cent of the material extracted and measured; 5369 litres, or 467 arrobas, of colofonia or resin, amounting to 78 per cent; and 1471 litres, or 128 arrobas, of spirits or essence of turpentine, equivalent to 20 per cent.; and 147 litres, or 12 arrobas, of water and other matters were lost by evaporation.

'To determine the expense, and returns of the resination of these 5000 trees, it is only necessary to state the value of the products at the fabrique or manufactory on the pinery of Villanueva : 46,7 arrobas of colofonia at 11 reals $*=$ $\check{137}$ reals ; 128 arrobas of aquarras, or spirits of turpen-

\footnotetext{
* The real is equal to $2 \frac{1}{2} \mathrm{~d}$.
} 
tine, at 60 reals $=7680$ reals; 5 arrobas of breas, tar resulting from the borras and impure resin, at 12 reals $=60$ reals in all, 12,877 reals.

'The expenses were:-

420 days' wages of the men, two in number, employed in collecting the resin, at 14 reals, - - 5880 reals 210 days' wages of a boy, assistant to them, - - 1260 ,"

10 per cent. interest on the capital of 15,000 reals invested in the small fabrique and utensils employed, : .

10 per cent. on the sum of these for unforeseen incidental expenses and the direction of the work, 1500, - 864 ,

9504 reals

'Deducting the expenses from the returns, there is a nett gain of 3373 reals, corresponding to a gain from each tree of 67 reals. With the problem thus solved, showing that it would be profitable and satisfactory to continue the resination of stone pines, the proprietor did not hesitate about submitting to this method of exploitation a greater number of trees.

'In the year following he subjected 75,000 trees to this treatment, and judging from the quantity of turpentine obtained during the first month of operation, it may be supposed that the products, if not superior to those yielded in the experiments of the previous year, would have been approximately equal to them ; but the political movements which were so accentuated in Cadiz and the province around, prevented the ascertaining in an indubitable manner of the entire production, as during a third part of the time of the resination the operations were stopped.

'Let it be supposed, and it is no great concession, that the 75,000 trees yielded proportionately the same profits as were obtained from the exploitation of the former 5000 , there would result a nett return of 50,574 reals.

' In the year 1874 the resination was extended to 120,000 trees, but the work has been stopped in consequence of ruinous losses to which the proprietor of the state has been subjected through operations of a different kind, and the lamentable depression of trade which has come upon all our larger towns. 
' By the resination of pineries similar to those of Villanueva, there is in no way whatever affected the produce in pasture and fruit, the seeds being in demand as such ; and firewood, and small-kneed timber, made use of in the construction of small vessels and boats, being unaffected either in quantity or in pecuniary proceeds. Tortuous and crooked trees, and those from which resin is collected, when these have yielded all the turpentine obtainable from them, admit of easy and convenient application to such boat and ship-building; and it should be known that the wood obtained from trees which have thus been bled, is better than those which have not so been treated, because from being saturated with turpentine, they decay or rot less readily and prove more lasting. The stumps, chips, and defective wood of trees, which cannot be used in carpentry, are appropriated for use in the manufacture of alquitran, pitch or tar.

'To effect the resination and extract the product, the following implements are used:-1. A cummon hatchet. This is used to clear away any roughness or projections from the bark, and the place where the incision is made. 2. A pitchman's batchet. This instrument has a certain curvature in the handle, and is used to make the flat wounds in the tree, and renewals of these. 3. A ladder. When the cutting cannot be reached from the ground it is necessary to make use of a light hand-ladder, or a threecornered pole or beam, with steps cut in it on two of the angles, that placed at an inclination against the tree it may enable the workman to reach the place on which he has to operate. 4. A rake; formed like a pick-axe or hoe, provided with a handle a metre and half long, which serves for clearing the bark at heights which cannot be reached with the hatchet. 5. A resin rake. This implement is used to rake off resin in a concrete or solidified state from the cuttings; it is composed of a short handle, and a curved blade of iron. 6. A shovel. This shovel is of iron, with a handle of wood, and serves principally for the removal of the resin to the bucket. 
7. A pitchman's bucket. This bucket is similar to those in domestic use ; it serves for the transport of resin to and from the receivers and the deposits. 8. Depots or receptacles for the resin. The depot depends in size on the magnitude of the fabrication, and care inust be taken to prevent the absurption of the spirit or oil of turpentine. What gives the best results is to line it with Roman cement, and paint this with pirogenudlo oil; precautions must also be taken against fire.'

There follows detailed information regarding the various processes employed in the preparation of spirits of turpentine, resin, pitch, tar, and lamp-black; and of the various uses to which these, and preparations from them, are applied with all of which it is considered desireable that the forest engineer should be acquainted, or in regard to which he should have at command the information which at any time may be required in the discharge of his functions. The volume by Senor Ceron was published in 1879 .

In a paper on the resin trade of Valladolid, by Senor D. Felipe Romero Gilsanz, which appeared in the same year, the writer says:- 'We do not undertake to describe the process of collecting the rough turpentine from the Maritime Pine, Pimus Pinarte, Sol., and the elaboration of this in the manufactory. Our purpose is more limited : it is to give a brief sketch of the resin trade in Valladolid, considered from an economic point of view ; and in entering upon this we believe that the deductions which may be drawn will prove applicable to a great extent to that industry everywhere throughout the Peninsula.

'Some eight years ago it was proposed to collect the rough turpentine, or raw resin, from 20,000 pine trees, as a means of obtaining a new product from the public forests ; and with a view to securing good results, attention was directed to what had been accomplished in this way in the district of Segovia. To the cutting of these pines succeeded the establishment of a resin manufactory within the bounds of the aforesaid town; and in the year 1874, by 
Senors Don Theodora Elias Huard, and Don Julio Touchard, there were liberally assigned for this on the plan still practised, the great number of 118,000 pines, of which 94,000 are now in course of being exploited, and the rest are to be disposed of by auction.

'Not only has a beginning thus been made, but we find there is being utilised in this way 8 per cent. of the produce of the forests; and that thus has been promoted the better conservation of those which enjoy the constant watchful care of the guards in charge of the erections for the manufacture of the resin.

'Assuming then, as a starting point, that there is obtained from each pine 3 kilogrammes of rough turpentine, which we do not consider to be at all an extravagant assumption, the annual product from the 94,000 trees mentioned will amount to 282 metrical tons; and a greater quantity than this niight be procured, in as much as the possible yield of the forest would admit of this, if all the measures favourable to this new-born industry were taken; but as up to this time it has nut been possible to get any extraneous impulse towards its developinent, we fear that the produce of the raw material will, on the contrary, be found gradually decreasing. This supposition is based on data, which in the sequel will be adduced, taken from the manufactory, of which the nephew of Don Julio 'Touchard has charge, which is distinguished alike for the skilful devotion under which it is courlucter, and for the exacti. tude of its management and accounts.

'Rate of cost of manufacture of 500 kilogrammes of resin in the manufactory in Valladolid:-

Hire of Pine Trees, $\quad-\quad \quad \quad \begin{gathered}\text { Pesetas* Cent. } \\ 3-74\end{gathered}$

Labour of Collecting Raw Material, - $\quad: \quad \div \quad 6=41$

Packages and Packing, : $\quad: \quad: 0-54$

Transport to Manufactory, : : : : $\quad$ : 1 -

Sundry Incidental Expenses, $\quad \cdot \quad \cdot \quad \cdot 0-58$

Total per 100 Kilogrammes, - $\quad \cdot \quad \frac{0}{13-12}$

* The Peseta, as has already been stated, is equal in value to a franc, and like it is
divided into centimes. 
' Cost of making 100 kilogrammes of distilled resin :-

Resin at Manufactory,

Pesetar. Cent.

Loss in Manufactory,

Wages,

Expense of Manufactory,

Fuel,

Packing of Material,

Vessels,

Total per 100 Kilogrammes,

$13-12$

$2-60$

$1-50$

$0 \div 80$

$0-48$

$0-32$

$1-50$

$20-32$

'The products obtained in the distillation of 100 kilogrammes are according to the following scale :-

Spirits of Turpentine,

Colofonia (Resin) No. 1,

., ", No. 2,

Pitch,

Residue and Loss,

No. 3 ,

Total,
Kilogrammes.

17

16

30

' Bearing in mind the cost of $13 \cdot 12$ pesetas, at which 100 kilogrammes of resin is bronght to the manufactory, which, when distillation is cumpleted, amounts to 20.32 pesetos. it will be easily calculated what the cost of these several products will be; and seen that the actual cost or price will be :-

Spirits of Turpentine,
Resin, No. ,,
", No. ,
Pitch, No. 3,

'What we have shown to be the expense of obtaining these products in the manufactory of Valladolid it may be presumed will, with slight differences, be the expense in the district of Segovia, at the manufactory of Coca, and supply the data required in judging of the resin trade; and may clear us of exaggeration in extending them to 
the products obtained at the manufactory of Las Navasthe conditions under which they are obtained in the two provinces in which they are situated being similar to that of Avila; and we may feel ourselves at liberty to make use of these data in discussing the competency of our home products to compete in our markets with products imported from abroad. Adverting then to the proximity of France to Barcelona, the first market in Spain for this class of produce, we find in the following tabulated accounts the disadvantages under which the Spaniards labour :-

\section{SPIRITS OF TURPENTINE.}

Freach Produce.

Actual cost in Dax,

Transport to Cette,

Transport from Cette to Barceluna, - - - : : :

Duty,

Cost in Barcelona of 500 Kilogrammes, - - - $\quad$ - $\overline{57-90}$

Spajish Produce.

Cost in Arevalo, Las Navas, or Valladolid, _ _ _ . Pes. Cent.

Transport to Barcelona at Railway Rates, - - - $7-75$

Cost in Barcelona of 500 Kilogrammes, . . . . $\overline{65-25}$

COLOFONIA OR RESIN, No. 1 ,

Frexch Prodtce.

Actual Cost in Dax

Transport to Cette,

Transport from Cette to Barcelona, $-1-90$

Duty,

Cost in Barcelona of 500 Kilogrammes,

Pes. Cent.

$14-50$

$1-90$
$1-70$

$0-25$

Spaytsh Prodece.

Cost in Arevalo, Las Navas, or Valladolid, Transport to Barcelona at Railway Rates,

Pes. Cent.

$18-75$

$6-75$

Cost in Barcelona of 500 Kilogrammes,

$25-50$ 
'The relative cost of spirits of turpentine and of resin, No. 1, indicate the relative cost of the other products, and show that France can put them in the market in Barcelona six pesetas cheaper than we can. In Santander, and other ports of less importance, the effects of this competition are less manifest, the inequality not being so great as in Barcelona; and if, from the French prolucts yielded by their renowned plantations, the Landes, we go to the products obtained on a great scale from American forests favoured by an exuberant vegetation, the Spanish products cannot successfully compete with these, since the expense of extraction and elaboration in America is mucb below what it is in Spain; and we have little to add to this for expense of trinsport, as vessels carry this class of products as ballast, at a very low charge for freight.

'From what has been stated it is manifest that the resin trade cannet be said to be in a lively condition, or to contain germs of vitality, seeing that it cannot compete with imports from abroad, which can be put in the market paying 10 pesetas for 100 kilogrammes cluty for spirits of turpentine, and 25 ceutimes duty for a like quantity of resiu, No. 1. It seems then to be indisputably necessary to raise the duty, especially that on resin, which is almost nil; for so long as the duties are what they are at present it is easy to account for the great quantities of the latter products being storer in the manufactories, and the difficulty in efferting sales.

'We do not consider that we are competent to discuss the graver question of general regulations, applicable to every case, which would require lengthened consideration and a clear judgment in regard to general utility; but what we think is that with a growing industry, as is the resin trade in our country, everything proper to increase it should be done, and so far as it presses, every difficulty should be taken out of its way, that it may compete freely with foreign products in the lome market. Every industry labours under difficulty which has in its beginning to bear equal burdens with those which are already established, 
in consequence of the natural obstacles which are always encountered in beginning anything new, notwithstanding that it requires, on the contrary, means to promote its development. This once secured, the new industry can, and should, bear its part in sustaining the burdens which fall necessarily upon a nation; but it is only thus, according to our judgment, that it can besome useful, as by gathering the fruit too soon the tree which yields it may be destroyed, while otherwise it might have yielded crops continually and plentifully.

'As the information solicited, by circulars dated Sth August last, should now be collected, we may presune that the Consulting Committee of Valuations and Regulations may now take up the question, and give a deliverance upon it. Granted the competence, and proper action of the persons comprising it, we may hope that they will be able to propose some measures to enable the resin industry to come out of its present lethargic condition; and we should greatly rejoice if these, and other forest industries of a similar character, should enter upon an era of progress and profit; and this would beyond all doubt redound to the increased pecuniary productiveness of our public forests.'

Sub Section 3.-Collection and Manipulation of Bark and Cork.

In connection with the collection of bark for tanning, there is supplied in the work of Senor Ceron information in regard to the quantity of tanuic acid yielded by the bark of different kinds of trees; and in the same year in which it was then published was published a work by Don Carlos Castel, Professor in the School of Forestry, eutitled Estudios sobre el Tanino: Memoria premiada con el accesit, por la Real Academia de Ciencas Exactas, Pisicas y Naturates, en la Concurs Publico, para 1876, Sobre el tema determinar el valor intrinsico de la materias curtientes o astringentes, referido al del I'anino producido por los vegetales de Cínco o mas provincias de Espanna; y exponer con la aproximacion posible, in edad de los vegetales, de donde proceden su cultivo, habitacion y estacion, epocas 
del anno mas favorables, para la recoleccion de los productos, $y$ las vias o medios de exportarios o conducirios a los MercadosStudies in Tannin-a memoir for which a prize was awarded by the Royal Academy of Exact Physical and Natural Science, at the public meeting in 1876 ; a prize offered for a paper on the subject of the determination of the intrinsic value of the tanning, or astringent matter in the tannin produced by the vegetables of five or more provinces of Spain, with a statement as precise as possible of the conditions of the vegetables from which the tannin had been obtained, the culture to which the plants had been subjected, their habitat, the season of the year most favourable for the collecting of the products, and the ways and means of exportation and bringing these to market.

A more important industry in Spain in connection with. bark is that of cork, yielded by the Quercus Suber which grows there abundantly; and on this subject also Senor Ceron supplies valuable information, uor is there any lack of special treatises on the subject.

In regard to the collecting and manipulation of corkbark, there was printed for private distribution in 1876 a pamphlet, entitled Elcornoque y la Industria Taponera, por Don Primitivo Artigas y T'eixidor, Ingeniero de Montes, Profesor Interino y Ayudante de la Essuela Especial del Ramo-The Cork Tree and Cork-Cutting Industry, by Don Primitivo Artigas y Teixidor, Forest Engineer, Interim Professor and Assistant in the School of Forestry. In this information is supplied in regard to the botanical character of the species; and to its different parts; the climatic and oiher physical conditions of its vigorous growth; the artificial production or replenishing of cork tree woods; the area of the growth of the tree; the exploitation adapted to it; the secondary products yielded by it; the enemies and diseases to which it is exposed; and the pecuniary returns yielded by the culture of it. In connection with the cork inciustry are detailed the preparation and manipulation of the sheets of bark; the manufactory and improvement of 
corks; and much relating to the commerce in corks and to other appliances to which the material is and may be put.

In 1879 there was published a work entitled Le Chene Liege en Algerie, par M. A. Lamey, Inspecteur des ForestsThe Cork Tree in Algeria, \&c. Of this, in 1881, Senor D. Primitivo Artigas, now Chief in the Corps of Forest Engineers, and Professor of Sylviculture, Meteorology and Climatology, in the School of Forestry, published in the Revista de Montes, and afterwards reprinted a Resena Critica or Critical Review And four years later, in 1885, he published as a reprint a pamphlet entitled Alcornocales Industrin. Taponica-The Cork Industry of the Cork-Oak-a part of a larger work reporting what had been made subjects of observation on a professional tour made with the students uniler his care, in the province of Gerona, in the spring of 1882.

Another work on the same subject is one published in 1884, Notas Sobre los Alcornocales, y la Industria Corchera de la Argelia, por D. Josè Jordana y Morera, Juťe de Primera Clase der Cuerpo, de Ingenieros de Montes; publicacion oficial del Vinistero de Fomento-Notes on the Cork Trees and the Cork Industry of Algiers, by Senor Jordana, Chief of the First Class in the Corps of Furest Engineers ; an official publication of the Minister de Fomento.

Appended to the first-mentioned work of Senor Artigas is the following list of works, cunsulted by him in the preparation of that work, which might prove useful to others engaged in the prosecution of the study of this subject, while it shows what provision was made for facilitating such studies by members of the corps:-

Alonso de Herrara (Gabriel).-Agricultura general.-4 vols. 1818.19. Madrid.

Barruel (G.)-Traite de Chimic appliquee aux arts et a l'industrie, a la pharmacie et a l'agriculture, -5 vols., 1856-60. Paris, 
Baudrillart.-Traite general des Eaux et Forets, Chases et Peches, \&c.-2 vols., 1823-25. Paris.

Boissier (Edmond).-Voyage botanique dans le midi de l'Espagne pendant l'annee 1837. -2 vols., 1839-45. Paris.

Bossh y Julia (Excmo. Sr. D. Miguel).-Memoria sobre la parte Forestal de la Exposicion de Londres de 1862.-1863. Madrid.

Bosch y Julia (Excmo. Sr. D. Miguel).-Memoria sobre la inundacion del Jucar en 1864.-1863. Madrid.

Candolle (Alphonso de).-Prodromus Systematis Naturalis Regni Vegetablis.-16 vols., 1824-73. Paris.

Colmeiro (D. Miguel). - Catalogo metodico de plantas observadas en Cataluna, particularmente en las inmediaciones de Barcelona.-1846. Madrid.

Collantes (Excmo. Sr. D. Augnstin Esteban).-Diccionario de Agricultura Practica $\mathrm{y}$ Economia Rural. -7 vols. and an Atlas.-1855. Madrid.

Comision de la Flora Forestal Espanola.-Resumen de los trabajos verificados por la Comision de la Flora Forestal Espanola durante los anos de 1867-68.69-70._2 vols., 1870.72. Madrid.

Costa y Cuxart (D. Antonio Cipriano).-Introduccion a la Flora de Cataluna, y Catalogo razonado de las plantas observadas en esta region.-1864. Barcelona.

Cutanda (D. Vicente).-Flora compendiada de Madrid y su provincia, o descripcion sncinta de las plantas vasculares que espontaneamente crecen en este territorio.-1861. Madrid.

Daunassans (A.)-Nouveau dictionaire d'Agriculture pratique. -1854 . Toulouse.

Duchartre $(P$.$) . - Elements de Botanique.-1867. Paris.$

Garcia Martino (D. Francisco) y Gonzalez de la Pena (D. Pablo). -Revista Forestal, Economica y Agricola. -7 vols., 1868.74. Madrid.

Girardin $\left(J_{\text {. }}\right)$.-Lecons de Chimie, elementaire appliquee, aux arts industriels. - 2 vols., 1860-61. Paris.

Gomez de Ortega (D. Casimiro).-Tratado del cuidado y aprovechamiento de los montes y bosques, dc., por D. MI. Duhamel de Monceau, traducido al castellano por el Dr. D. Casimiro Goinez de Ortega._2 vols., 1873-74. Madrid.

Grenier et Godron.-Flore de France, ou description de plantes 
qui croissent naturement en France, et en Corse. -3 vols., 1848-50-55. Paris.

Heyer (Dr. Gustavo).-Allgemeine Forst-und-Jagd-Zeitung.Veintiseis tomos: 1848-74. Frankfurt am Main.

Joigneaux (P.) et Moreau (E.).-Dictionaire d'Agriculture pratique. -2 vols., Paris.

Junta Directiva de la Exposicion.-Memoria sobre los productos de la Agricultura espanola, reunidos en la Exposicion general de 1857-61. Madrid.

Koch (D. Guil Dan Jos).-Sinopsis Florae Germanicae, et Helveticae. -3 vols., 1843-45. Francofurti.

Laboulaye (C.).- Dictionaire des Arts, et Manufactures de l'Agriculture, des Mines, \&c. Description des procedes de l'Industrie Francaise, et etrangere. -2 vols., 1853-54.

Lambert (Ernest).-Exploitation des Forets, de Chene-Liege, et des Bois d'Olivier en Algerie.-1860. Paris.

Liebeg (Justo).-Tratado de Quimica organica publicado en frances por Ch. Gerhardt.-Traduccion en espanol, por Saez y Ferrari.-4 vols., 1837-48. Madrid.

Parlaiore (Filippo).-Flora italiana, ossia descrizione, delle piante, che crescone spontanee o vegetano como tali in Italia e nelle isole ad essa Aggiacenti._5 vols., 1848-73. Firenze.

Pelouze (J.) et Fremy (E.).-Traite de Chimie generale, \&c.6 vols. and an atlas, 1855-56. Paris.

Quer (D. Joseph).-Flora espanola o Historia de la plantas que se crian en Espana._6 vols., 1762-84. Madrid.

Rozier.-Nuevo Diccionario de Agricultura-teorico-practica y eeonomica y de Medicina domestica y Veterinaria.-1842-45.

Societe d'Agriculturc.-Memoires d'Agriculture d'economie rural et domestique, publies par la Societe d'Agriculture.73 vols., ano IX : 1856 . Paris.

Tessier.-Annales de l'Agriculture francaise-ano VI: 1855. Paris.

Willkohmm (Mauritius) et Lange (J.).-Prodromus Florae Hispanicae.-3 vols., 1861-74. Stuttgartiae.

Semanario de Agricultura y Artes, dirigido a los parrocos. 23 vols., 1797-1808. Madrid.

Annales Forestieres. -24 vols., 1842-65. Paris.

Revue des Eaux et Forets. - 13 vols., 1862-74. Paris.

Comptes rendus, hebdomadaires des seances de l'Academie des Sciences. -77 vols., 1835-73. Paris. 
Seltior 6.-Jurispredence ANd Political Economir.

From the first it was considered desirable that in the School of Forestry in Spain, as is the case in those of many, if not also of all such schools in other countries, the studeuts should be instructed in the principles and in the administration of law. In this, as in other departments of study, the professors appear to prepare a programme of what they consider desirable should be talight to the students, which programme requires the approval and sanction of the authorities of the school; and provision was made for this being done in the earlier programmes of those schools which were projected but were not established.

The following is a summary of a handbook of study in this department, issued in 1861, five-and-twenty years ago, which shows what subjects were embraced in this department of study at that time. It is entitled Lecciones de Administracion Forestal; apuntes de la Clase-Lectures or Instruction in Forestal Administration; Notes for the use of Students.

It is intimated in the text that what is referred to in the title is the administration of for est law; and under successive heads there are indicated the subjects of successive lectures, embracing:-1. Notions of property in general. 2. Application of proprietorship to the territory of forests. 3 . Servitudes. 4. Duty of the State to maintain in favour of itself the legal presumption of the proprietorship of forests on disputed or doubtful property, at least till the contrary be proved and established. 5. That law-suits in regard to forests should always be prosecuted in the most suitable manner, and, if possible, in the regular administrative way, so as not only to facilitate and expedite the suit, but to ensure the execution of the judgment. 6. That the Government administers of its own right the forests of the State; directs for public convenience the service or management of forests belonging to communities and corporations; and in the forests belonging to private proprietors exercises 
police powers conformably to the laws and local regulations. 7. Duly and behaviour of engineers in the service. 8 . General idea of the organisation of the Government of Spain.

In this handbook the distinction between possession and proprietorship is distinctly drawn. The State, by which it is explained is to be understood the Community, is held to have the sole right to hold land of its own right, but also to have the right to transfer possession, constituting thus what is known as private property, which again may be limited by servitudes, and rights of usage recognised by the State-with the Government as its representative. It is stated that while some nations hold that proprietorship extends de ceilo a ceilo-from the surface to the antipodes, Spain, with some other nations, holds that it extends only to a certain depth, the determination of which depth affects the decision of questions raised as to the proprietorship of minerals; and that the proprietorship of forests comprises that of the soil and vegetable covering, herbaceous and lignous. There are discussed changes which have taken place in consequence of the diminished importance of pasturage in forests, aud the increased importance of firewood and timber. It is alleged that in Spain the proprietorship of the forests has never been abandoned by the State, and that the tenure or possession is limited by servitudes and usage. Of servitudes there are recognised three categories - urban, rustic, and mixed. In the first mentioned are comprised rights to light, rights to form gardens, and rights of water-flow to and from the property. In the second are comprised right of pasturage, right of erecting fences, with right to the soil for culture of crops, and right of use of forest products; and it is stated that there are special servitudes peculiar to different provinces. It is maintained that the State ought not to part with its legal right of possession, beyond the limits imposed by cosmical, geographical, and social requirements of the country, or of the district, which would be affected by any such transfer; 
and there are specified what constitute prescriptive rights of private property, which are confined to what can be supported by legal evidence of just title, and continuous possession for not less than 10,20 , or 30 years, according to circumstances. Importance is attached to proper provision being made for the prosecution of forest misdemeanours and offences, and to safeguards against the miscarriage of justice-the governing Administration having a right to prosecute in the interests of the nation, and the forest officials in cases of wrongs committed in forests belonging to communities and corporations, and even in the case of the forests belonging to private individuals, prosecuting conformably to the laws and local regulations.

The following is a translation of what is stated under the head of Lecture VJII.-General Idea of the organisation of the Government of Spain :-

' To the formation of a just idea of the Administration of the State, it is necessary to have some knowledge of the nature of government in general, and of the particular distribution of its functions. To communicate this is the object of this lecture.

'The present Government of Spain is a Constitutional Monarchy, or, what is the same thing, the King rules in accordance with the Constitution of the State.

'The Constitution establishes three powers; namely, the Legislative, the Executive, and the Judicial.

' The Legislative power is exercised by the King, with the Cortes. The Cortes is composed of two co-legislative bodies, which are the Senate, the members of which hold office during life, and the Congress of Deputies, who are clected temporarily in the provinces, in accordance with a special law.

'The King convokes, suspends, and dissolves the Cortes in a form prescribed by the Constitution. With him lies the initiative and the sanctioning of laws; and he may 
assemble the Cortes in any place which seems to him convenient. For the promulgation of a law there is requisite the perfect agreement of the co-legislative bodies and the sanction of the King. A law once promulgated, its arrangements cannot be altered excepting by another law enacted by the Cortes; but the Government may explain, and secure the operation of it, by means of Regulations.

'In general terms it may be said that there pertain to law all the arrangements which effect directly the government of the State; those which create or annul established rights; those which interpret or substantially alter other existing laws: the general arrangements in regard to taxes, and the public service, or the maintenance of the army and navy, which ought to be voted annually.

"The laws ought to embody in a concrete form, and to establish rules. The Regulations ought to explain the application to be made of the same; and special Instructions of Service, special details required in the execution of the Regulations in any case, and to determinate cases of which they treat.

'There is nothing more difficult or more important in practice than to determine how far the Precepts of a law ought to extend; at what point the arrangements in the Regulations ought to begin to operate; and what are the details which ought to be entrusted to the Instructions of Service. Hitherto, so great has been the want of agreement on these points, that the greater part of the laws may be frustrated, or made of no avail in practice, by comprising in the law what ought to bave been left to the discretionary flexibility of regulations, and by including in regulations what can only be pointed out in an instruction of service.

'The Executive power, as its designation denotes, is that which is charged with the execution of the laws, and with the direction of the government of the State.

'The King exercises this power, which is called Govern- 
ment, in the widest comprehension of the term, by means of responsible ministers. The King participates in the legislative power in the manner which has been indicated, and in respect to the government of the kingdom he holds in his hands the army and the navy; he declares war, makes peace, and signs treaties; he confers all appointments, honours, and dignities; he grants gracious pardons, and he sees to the internal and external security of the State.

' The Judicial power is exercised in the name of the King by tribunals of justice, whose puwers are confined to judging, and carrying their judgments into effect.

" This power holds as fundamental the immutability of justice, because in no other way can be conceived the independence of the tribunals; but the circumstances of the country have not hitherto permitted the establishment of this immutability, and consequently it may be said that this power has not existed amongst us hitherto, as it is recognised by the constitution of the State. On the other hand, the constitution assumes that we cannot have more than one standard for the Spanish people; and that the whole kingdom must be governed by codices, which has not been absolutely realised.

At present, besides the ordinary jurisdictions, there exist those of war and the navy, the ecclesiastical, the special judicatories of the exchequer, and the tribunals of commerce. Lest any case should arise which is not fully provided for by these tribunals, the powers of the common courts are curtailed to some extent by the establishment of what is designated the Judicial Administration sanctioned among us by special laws with an appropriate prescribed procedure, and with a recoguised place between the judicatories and tribunals, in which it exercies the supreme functions of the Council of State.

'It will be understood that these indications are confined to the matters of fact, without entering upon a discussion of the principles involved, which would be arduous and delicate enough under whatever conception the subject might be brought under consideration. 
'In representative Governments the King alone is inviolable; all the other public functionaries are responsible for their acts, as strictly speaking there is no sorereign power but the legislature.

'The responsibility of the Ministerial Secretaries of Despatch is to the Congress and Judges of the Senate sitting as a constituted tribunal of justice. Accomplices of Ministers in delinquincies, are however, judged by the Senate itself. In the trials of other functionaries these are heard according to their classes by the tribunals to which they severally pertain.

'The King holds by the Constitution the power of submitting to the cognisance of the Senate, as tribunal of justice, grave crimes committed against his person or dignity, and against the security of the State.

'The Senate sits, moreover, as a tribunal in criminal trials of Senators.

'The King exercises the government of the State as Supreme Chief of the Executive power, by means of seven Ministers. These are that of the State, that of Grace and Justice, that of War, that of the Navy, that De Haciendo, that of the Goverument, and that De Fomenio.

- The seven Ministers form a Council, which is under the presidency of one of their number, with or without a portfolio, who is usually he who has been entrusted by the King with the formation of the Cabinet. In this Council are treated the general business of the State, and those special matters which give form to the law. The Royal Decrees are always issued with the accord of the Council of Ministers, and to that extent involve obligations on all the authorities and dependencies of those Ministers.

'The president ought to take upon himself the direction of foreign affairs, and what relates to the general statistics of the kingdom. If he do not do so he delegates these functions to other Ministers, by virtue of Royal Decrees.

'The responsibility involved in resolutions of the Council of Miuisters is collective, and cannot be confined to any particular Minister. 
' 1. The Minister of State, or of Foreign Affairs, as he is designated in other countries. By this Minister is managed such business as arises from abroad; and for the management of this he has a diplomatic corps, which attends to the affairs of Government, and a consular body, which has under its immediate charge what relates to the commerce of Spaniards at the places of their residence.

'The Diplomatic Corps is composed of Ambassadors, Ministers-Plenipotentiary, Resident Ministers, Cliargés d'Affaires, Secretaries of Embassy or of Legation, and effective attachés with a salary, and honorary attachés without position.

'The Ambassadors represent the person of the King, with powers to treat of all kinds of business.

'The Ministers-Plenipotentiary represent the Government, and hold likewise ample powers.

'The Resident Ministers attend only to ordinary business, and such extraordinary business as may be entrusted to them.

'The Chargés d'Affaires are those who act as substitutes for resident Ministers, and may be entrusted with most kinds of business, but nore as a commission than as a function of their position.

'The Secretaries of Embassy and Legation exercise functions indicated by these designations; and the attachés are a kind of official anxiliaries, who work under the immediate orders of the Secretaries.

'The Consular body consists of Consuls and ViceConsuls. To Consuls of the first class is given the title of General. Those who serve in states on the coast of Africa, and in some places in India, discharge functions connected with the charge of commercial business, but they pass nevertheless into the position of the diplomatic corps.

'The Consuls possess public credit, and may certify as notaries documents and papers which are granted by Spaniards, within the limits of their respective consulates. They may, moreover, also intervene in the execution of 
testamentary deeds, and proceedings relative to prizes, damages, and other similar matters. In general, the Consuls represent officially the personal rights of Spaniards ; but they do not possess any footing in the representation of affairs of Government, which pertains to the diplomatic corps, or only do so in special specified cases, if these have been entrusted to their charge.

'In the interior of the kingdom there depends on the Ministry of State the supreme ecclesiastical court De la Rota; the office of interpreters; the general commissary of the holy places at Jerusalem; the negotiations with Rome relative to public worship; the permanent Deputation of the grandees; the disposal of the crosses of the Golden Fleece, of Cbarles III., of Isabella the Catholic, and of the noble dames of Maria Louisa and St. John of Jerusalem; the four Societies of the knighthood of the kingdom, namely those of Seville, Granada, Valencia, and Ronda. There pertains, moreover, to this Ministry certain functions in the internal government of the palace; these, however, are not at present in use. By this Ministry also are dispensed the rewards of the Grandees of Spain, and are ordered the ceremonies to which these concessions give occasion.

' 2. The Minister of Grace and Justice. This Minister, as the name indicates, has charge of business relating to the ordinary administration of justice in the kingdom; the dispensing of grants and rewards; the afficirs of the Royal ecclesiastical patronage; and the Seal of the State; with the higher notarial powers of the kingdom exercised by the Minister.

'The principal functions of this Ministry in the department relating to justice are:-1. To see that this is administered exactly and completely by the tribunals of ordinary jurisdiction, suspending from their functions and prosecuting any judges who fail in their duties. 2. To nominate, in accordance with the laws, the ministers of the supreme tribunal of justice, the magistrates and fiscals of 
the courts, and the judges of first instance and prosecuting fiscals, and the other under-officers of the courts, be they clerks, notaries, recorders, or other subaltern officers of justice ; and amongst other duties to present or instal such as hold office by right of inheritance, and who consequently cannot be elected. 3. To provide the material which the tribunals require for the performance of their service with becoming decorum. With regard to the department relating to grants and rewards, it has charge of pardons, concessions of 'Titles of Castile, the habilitation of minurs in the administration of their possessions; and, in general, all those dispensations of law called grants of extract, for which certain dues must be paid to the Chancery. With respect to ecclesiastical patronage, this Ministry is charged with the presentation of the archbishops and bishops to the Pope; the nomination of canons and ecclesiastical prebendaries, according to the form established by the concordat; the provision of curates in accordance with the minutes of competition which come from the dioceses: the protection of the clergy, by recourse to force if necessary; the promulgation, or it may be the exequatur, of bulls and pontifical briefs; the disposal of the funds granted for the maintenance of worship and of the clergv ; and in general, all business relating to the ecomic regimen, the policy, and the protection of the Church, of which the King is the permanent and supreme defender in Spain.

'Moreover, the Council of the military orders of Santiago, Calatrava, Alcantara, and Montesa, depend on this Ministry for the episcopal functions which they discharge in the Churches of the order - which, by the last concordat, has been reduced to a very small number indeed.

The Seal of the State is entrusted to the Chancery of this Minister, on whom, moreover, depends the decision relative to the circumstances which require its application to executed deeds; and the notarial record of the power exercised by the Ministry of Grace and Justice alone sanctions its use in authenticating solemn deeds in the 
State, such as those relating to the birth and marriage of the Princes, Acts of the Cortes, and other similar matters.

'3. The Minister of WAR. The Secretary of State, entrusted with the despatch of the business of this Ministry, has under his charge all business relating to the personnel, the material, the service and the administration of justice, of the military in peace and in war. 'The personnel comprises all, from the captain-general of the army to the soldier inclusive. The Government business, of every kind which has reference to these persons, is discharged through the Direction-Generals of the armies of infantry, cavalry, artillery, and engineers, and the Inspection-Generals of the organisations of the civil guard, and of the carabineers of the coast and the frontier. These corps, it may be well to remark, depend also, the first on the Ministry of Government, and the second on the Ministry De Hacienda; they are, however, dependant on all that relates to their organisation, recruiting, and discipline, on the Minister of War. Personal affairs, and privileges of war, are also attencled to by this Ministry, with the difference that complaints are sent through the captainsgeneral in their places of retirement, or those in which they reside, and not through the Direction-Generals of the army. Also the material of victuals, cluthing, hospitals, and utensils pertaining to the corps of administration and military health, and the armament of the troops, and places for the manufacture of powder, parks of artillery, and foundries, are under charge of the corps of artillery. The works of furtification, with their dependencies in peace and war, pertain to the Corps of military engineers. The service is directed in the provinces by the captains-general, and in the field by the generals-in-chief of the army.

' Justice is administered by Councils of WTar, when it has to do with purely military crimes; and by the tribunals of the captains-general of the provinces when it has to do with civil cases, or criminal trials for common crimes. 
'The Courts-Martial are held by the captain when the accused is a member of the troop; and by general officers when the accused is an officer, whatever may be his rank. The sentences of the captain's court are executed only with the approval of the captain-general of the district. Those of the courts of generals, when they are condemnatory, require the confirmation of the King, after previous advice by the Supreme Tribunal of war and marine.

'The Corps of Artillery, Engineers, and Military Administration, retain their cwn special courts. These courts take cognisance in the first instance of business, and disputes relative to the personnel, material, and service of these corps; and the appeals from these courts are addressed to the Supreme Tribunal of war and marine, in the same form as is used by the courts of the captainsgeneral.

'The civil pleas and criminal trials of those who infringe the laws of war, are prosecuted and lecided in the courts of the captains-general. The tribunals of common law take cognisance of litigations relative to inheritances. Amongst those who are holders of privileges there are some who are entirely subject to military law, that is to say whether relating to civil or criminal prosecution-others are so only in regard to crininal proceedings.

'The ordinary courts-martial are composed of the captain-general of the district, of an auditor, a fiscal, and a clerk or war secretary. When the captaingeneral dissents from the judicial sentence of the auditur he remits the proceedings to the decisions of the Supreme Tribunal of war and marine.

'The infantry and cavalry, and the special corps of artillery and engineers, have their respective schools of cadets. The military administration manages the establishment of these.

'The supreme assemblies of the military orders of San Fernandu and San Hermenegildo, have charge of the Supreme Tribunal of war and marine, 
'The Minister of Marine. The organisation of this Ministry is analogous to that which exists in the Ministry of War, just detailed, with the difference that the Directions and Inspections of the different institutions and services are connected with the secretariat of the office.

'In the nomenclature of these Directions, and in the names of the personnel of the navy, may be noted certain variations which it may be well to indicate, that they may not be confouuded with those of the army when there is occasion to make use of them.

'The Directions-General of the Navy, attached to the secretariat of business, are known under the following names:-The Directiva Junta, or Council of the Minister; the Direction of marine engineers ; Direction of armament; expeditions, and stores; Direction of the personnel; Direction of 'the marine list, and the personnel of crews; Direction of marine, artillery, and infantry; Direction of accounts, and of the administrative corps.

'In the naval military personnel, the gradations of rank and their names are in every respect similar to those of the army, but the major-generals are called chiefs of the squadron or admirals; the colonels, captains of the navy; the lieutenant-colonels, captains of frigates; captains, lieutenants of the navy; lieutenants, ensigns of the navy; and the cadets, marine guards.

'In the personnel of the crew, those who attend to the observation and direction of the boats are named pilots; boatswain and boatswain's mate are names given to kinds of sergeants holding on ship-board a position similar to that of these in the army ; and ship boys and cabin boys, to those of the rank of troopers in the army. In the navy they have only three Captains-general of Departments, which are those of Cadiz, Carthagena, and the Ferrol. Those which exist in foreign provinces are called Commandants-general, or Commanders of naval stations.

' The administration of justice in the navy constitutes a distinct jurisdiction, as does that of the army; and it is 
adninistered by the commandants of the naval stations, and auditories of departments, subject to appeal to the Supreme Tribunal of war and the marine.

'The enlistment of the crews of the navy is governed by special ordinances, and they enjoy the privileges of the navy, with other exemptions and privileges in ports.

'There is a Naval College, for the instruction of the inarine guard, in the city of Sau Fernando; and various special schools in different places for the training of marine engineers, naval artillery, and piluts for the merchant service.

'The Minister de Hacienda, or of Finance. By this Ministry is transacted all business relative to the possessions, rights, imposts, contributions, and general charges of the State.

' For the discharge of these functions thereare constituted departments of the Ministry: the direction-general of the treasury ; that of accounts of State funds; that of general contributions; that of revenues of monopolies; that of taxes on articles consumed, the money office, and the mines; that of duties and customs; that of lotteries; that of the bank of depusit; that of the properties and lues of the State; and that of general assessments of the chancery. There depend, moreover, on the same Ministry the court of exchequer ; the direction-general of the public debt; the commissiou de Hacienda of Spain in foreign lands; the junta of elective classes; that of the sale of national possessions; that of regulations; and that of the portion of the corps of carabineers engaged in the service of this Ministry; with other dependencies of lesser importance.

- In the Ministry of Finance are collected the estimates of income and expenditure of the other Ministries; and by it is presented to the Cortes the budget or general estimates of the State.

'The Administration of Justice special to the exchequer is coufined to affairs which are within its own competency; 
and is secured by special courts, appeals from which go to the audiences of the territory, where this Ministry has fiscals appointed by itself there to defend its rights.

- We may summarise the functions of this department by saying that the Minister de Hacienda is the only administrator and collector-general of all possessions and revenues pertaining to the State. It is important to notice that having the supremacy over the ancient Intendancies de Hacienda which exist in the provinces, it exercises the principal powers in the civil governments of these.

'The Minister of Executive Governnent. This Ministry, as its designation indicates, has in charge the interior administration of the kingdom, in its multiple and separate branches ; but experience having demonstrated the difficulty, if not the impossibility, of one Ministry being able alone to undertake the charge of such vast and extensive dependencies, it was deemed necessary to form separate Ministries to attend to the more important departments of these-creating, as has been done in France and other nations, Ministries of public works, agriculture, commerce, and public instruction, to which have been given the names of these particular departments.

'The Spaniards, to effect such division, have formed two great groups, giving to the one the name of the Gobernacion, and giving to the other that of Fomento, charging each respectively with the functions which these uames continue to describe.

'The Ministry de la Gobernacion discharges business relating to the public administration, and the governing regimen of the population, by means of the directionsgeneral of the administration; the post office; penal establishments; beneficence; health; and telegraphs.

' In the provinces it exercises the government by civil governors, assisted by provincial councils and courts of provincial deputies, of which they ex-officio are presidents. 'The local government of the population is dispensed by Alcaldes, Mayors, or rather by the Alcalde-Corregidores, where there 
are any ; assisted one and other by Ayuntamientos, or Town Councils, corporations which, like the courts of provincial deputies, although popularly elected, perform various economical functions dependent on the Government.

'The laws of 1845 limit the power of these deputies aud ayuntamientos to business purely administrative, and it is also required, in regard to the greater part of their decisions, that they should receive the approval of the Government.

- The Administration of Justice in disputed administration is under the charge of this Ministry, and consequently dependent on it are the Council of State, and the provincial councils, to which is entrusted the cognisance of appeals. Moreover, in dependence on this Ministry are the Council and provincial juntas of the health of the kingdom; the Academies of medicine and surgery; the Pharmaceutical college of Madrid; the medical officers of medicinal baths; the. Aranjuez college for orphans; the savings banks; the Monte de Piedad of Madrid; the Junta for aid to prisoners ; the Government printing press.

'The same Ministry of Government attends to the regulation of the press; the election of deputies to the Cortes; the election of provincial deputies, and of ayuntamientos or town councillors; and carries on the correspondence with the co-legislative bodies in all matters in which the Government has to correspond with them. Finally, it has at its orders the civil guard, which is a corps of the army of from 10,000 to 12,000 men-as remarkable for its organisation, as distinguished by its services. The rural guards is also dependent on this Ministry.

- The Minister de Fonexto. This Ministry has under its charge public instruction; agriculture, industry, and commerce; and public works. There are entrusted to this Ministry vast and complicated interests; but there are not given to it agents of its own in the provinces, so that its principal representative and director of operations is everywhere the civil governor of the province; and this 
functionary is appointed by, and depends immediately upon, the Ministry of Government. This difficulty has not passed unobserved in this department; and it not hiving received power to create equal superior chiefs in each of the provinces, this has led to one of those inconveniences which occusionally occur-the despatch of business by partial arrangements, which do not accomplish all that was designed; and this in the end has led to the formation of Sections de Fomento, which in reality are no more than a kind of special secretariat of the governors, appointed by the Ministry de Fomento, to hear, consider, and formulate the resolutions of the said governors on matters pertaining tn this Ministry.

'On the Ministry de Fomento depends for the direction of public instruction the royal council of that narne ; and all the universities, institntes, academies, general archive; and libraries of the king.lom; the schools, as well superior as professional and industrial; with all the other provincial and local establishments designed for communicating instruction in it various forms and grarles.

'On the Direction-General of Agriculture, Industry, and Commerce depend the personnel, material, and service of the corps uf engineers of mines and of forests, with their Facultative Juntas or professional councils, and their special schools; the Royal council of agriculture; the Royal commissions; the juntas and committees of the provinces; the over-ight of the breed of horses; the general association of cattle rearers; the economical societies; the tribunals and juntas, or councils, of commerce.

' On the Direction-General of Public Works depend the corps of engineers of roads, canals, and bridges, with the consultative conncil, and the special schools of the department; the syndicates of irrigation ; and also all committees of inspection of other kinds whatsoever, which have to do with railways, waters, light-houses, and public works of other kind whatsoever among dependencies of the $.1 /$ inistry de Fomento. "ithe diplomas or commissions of $\mathrm{p}$ ofessional careers are issued $b_{y}$ the Ministi!y de Fomento. 
'The Engineers of Mines, Roads, and Forests hold Royal warrants for the ranks entrusted to them in their corps, with continuous salary.

'It may be well to bear in mind, in view of cases which may occur, that the department of forests had, until the second period of the century, a directing and administrative relation with the llinistry of marine with its own tribunals, and a multitude of powers and privileges which have disappeared being courts incompatible with the legislation now in force.'

With regard to the government of colonies it is added:- 'The possession abroad, according to the constitution of the State, should be governed by special laws. These laws, however, have not yet (1861) been enacted, consequently the islands of Cuba and Porto-Rico, the Phillipines and Fernando, Po, \&c., continue to be governed by the old laws of the India, and by ordinances, and Royal decrees, which are issued to meet cases as they arise. The inhabitants of these are not represented in the congress of deputies; but they are in the Senate, when there occur the conditions prescribed for that case. The Captains-general of some dominions hold the supreme position in all branches of the public administration; but these are subject to be caller to account before the Supreme Tribunal of justice when they terminate their appoiutment.

'Through the Direction-general of foreign affairs they disciarge under the president of the council of miristers, ol' on the minister substituted for him in this matter, the business assigued to the Ministries of grace and justice, hacienda, government, and fomento.

' The despatch of affairs of State, of war, and of marine, is retained in the hands of the ministries of the peninsula, as the nature of such business does not admit of its being separated. It is, however, enjoined that the secretaries of despatch of the ministries mentioned shall send to the Direction of foreign atfiairs a list of the orders which they 
have communicated-these being cummunicated to the authorities by the secretaries, in order to prevent the occurrence of contradictory arrangements relative to the same affairs being sent by two or more ministries, as has repeatedly occurred in some remote countries when these conflicting orders were followed with fatal effect, as well in respect to the service as in respect to the prestige of the government at the capital, which it is of much importance to maintain in these.'

The citation is a long one; but the matter may prove r.ot without interest to some of my readers while it supplies at once an illustration of the comprehensiveness of the course of study followed in the School of Forest Engineers in Spain, and the cxhaustive character of the studies.

\section{Section 7.-General Forestal Literature.}

The accounts given under preceding headings of different works were designed simply to supply some illustration of the kind of provision made for students in the School of Forest Engineers prosecuting their studies in each department of instruction embraced in the programme, being accounts of books taken almost at random in so far as this use of them was concerned. They supply an average, not a special indication of what is provided; and the provision is mucb more copious than these citations aloue would iudicate. Mention has beeu made of the number of books in the library of the school being, according to information in my pussession when previous sheets were sent to press, being 5665; from information since communicated to me I learn that they now number upwards of 7000 .

In an appendix to an Escalafón of the Corps of Forest Engineers which appeared in the Revist de IFontes, on the 1st July this year, 1886, there is given the following list 
of works published of late years by members of the corps, copies of all of which are accessible to the students. The arrangement followed is that of the alphabetical order of the names of the authors :-

\section{Acebal del Cueto (D. Ricardo).} 1885.

Proyecto de casa de guardas para el monte Pelono.-Madrid,

$$
\text { Alvarez Sereix (D. Rafael). }
$$

Determinacion de la masa lennsa de un monte, por P. Nico (Translated from the Italian). -Madrid, 1880.

Cartas de Navarra.-Madrid, 1880.

La desamortizacion forestal.-Madrid, 1883.

Estudios botanico-forestales (12 serie).-Madrid, 1885.

Geografia botanico.-Lugo, 1884.

Estudios botanico-forestales (2 $2^{\mathrm{a}}$ serie).-Madrid, 1885.

Cuestiones cientificas. -Madrid, 1885.

La opinion de la prensa sobre los montes publicos.-Madrid, 1886.

Discursos pronunciados en la Asociacion de Agricultores de Espana.-Madrid, 1886

Adiciones y enmiendas a la ultima edicion del Diccionario de la Academio Espunola.-Madrid, 1386.

Arrillaga y de Garro (D. Francisco de P. de).

Compendio de Valoracion de montes, por G. Heyer (Translated from the German).-Madrid, 1871.

La produccion forestal en la Exposicion universal de Viena.Madrid, 1875.

Resena del Congreso y Exposicion de Gengrafia en Venecia.Madrid, 1882.

\section{Artigas y Teixidor (D. Primitivo).}

El alcornoque y la industria taponera.-Midrid, 1875.

Resena critica de la olbra (Le chene-liege en Algerie), por M. A. Lamey.-Madrid, 1881.

Los torrentes de Barcelonnette.-Madrid, 1881.

Breve resena critica relativa a la obra intitulada (Nota solve los alcornocales y la industria corrhere de la Argelia), por D. Jose Jordana y Morera.-Wadrid, les:?. 
Memoria relativa a la excursion verificada por los alumnos de la E'scuela especial de Ingenieros de Montes a los montes publicos, dunas y alcornosales de la provincia de Gerona por el verano de 1882.-Madrid, 1885 .

Alcomocales.-Industria taponera.-Madrid, 1885.

Dunas.-Madrid, 1885.

\section{Bachiller (D. Buenaventura).}

Dictamen sobre las causas que influyen en las continuadas sequi is que experimenta la provincia de Valencia y medios que tiendau a corregir lus.-Valencia, $187 \mathrm{~S}$.

$$
\text { Bosch y Julia (D. Miguel). }
$$

Manuel de mineralogia.-Madrid, 1858.

Manuel de botanica.-Madrid, 1858.

Memoria sobre la parte forestal de la Exposicion de Londres de 186?.--Mudrit, 1863 .

Memoria solve la inundacion del Jucar en 1864.-Madrid, 1866. Parte forestal de la ultima Exposicion de Paris.-Madrid, 1869.

$$
\text { Bragat y Vinals (D. José). }
$$

Guia practira para combatir y atajar la phyloxera vastatrix.Zaragoza, 1878.

Influencia de los montes en la hidrulogia de un pais.-Zaragoza, 1879 .

$$
\text { Brenosa y Tejada (D. Rafael). }
$$

Estacion meteorologico-jorestul de San Ildefonso.-Madrid, I882. La profiritus y microdiuritus de Sün llderonso y sos contornes. -Misirid, 1834.

Una macla de yeso. - Mindrid, 1885.

El dimorfismo del basilicato de cal.-Madrid, 1885.

Guic del Real Sitio de Sinn Ildefonso (En colaburacion con el Sr. Castellarnau).--Madrid, 1885.

\section{Campuzano y Brochowski (D. Antoniu).}

Sistema de podas de arbolrelo, con notas.-MIadrid, 1864.

$$
\text { Castel y Clenente (D. Carlos). }
$$

Monog.:- dasngrafica del he, a,-Madril, 1873. 
Memoria sobre la Inflienciu de la luna en la vegetacion.Madrid, 1875.

Memoria sabre la fundacion y dessarrollo de la Escuela especial de Ingenieros de Moutes.-Madrid, 1877.

Estudios sobre el tanino (Memoria premiada por la Real Academia de Ciencias).-Madrid, 1879.

Descripcion fisica, geognastica, agricula y forestal de la provincia de Guadalrijurce. (Publicada por la Comisiou del Mapa geologico de Espana.)—Madrld, 1882.

Memoria sobre las condiciones naturales y produccion agricola y forestal de la Peninsula Escandinava.-Madrid, 1883.

Cambustibles vegetales: Teoria y practica de la combustion, carbonizacion y destilacion de la madera.-Madrid, 1885.

Castellariau y de Lleopart (D. Jozquin Marie de).

Estudio ornithologico del Real Sitio de San Ildefonso y sus alrededores.-Madrid, 1877.

Estudio mierografico del tallo del pinsapo.-Madrid, $18 \delta 1$.

Estudio micrografico de la madera de la coniferas espanolas, y especialmante del genero (Pinnats).-Madrid, 1834.

Guia del Real Sitio de San 1ldefonso. (Fn colaboracion con el Sr. Brenosa).-Madrid, 1885.

Vision microscopica.-Madrid, 1885.

La estacion zoologica de Napoles y sus procedimientos para el examen microscopico.-Madrid, 1885.

Descripcion microscapica de la madera del Quercus Jordanu.Madrid, 1885.

\section{Ceron y Martinez (D. Salvador).}

Cultivos de las estepas y dunas de las provincia de Cadiz.Madrid, 1877.

Industria fores/al-agricola-Codiz, 1879.

Estudio sobre los materiales y efectos usados en la marina.-. Cadiz, 1883.

Conpaxo y Rosset (D. Manuel).

Apuntes de botanica.-Fitografia,-Escorial, 1884.

Diaz Oruelos (D. Jose).

Prontuario forestal.-Burgos, 1877. 
Diaz Rocafull (D. Aurelio).

Legislacion del ramo de montes.-Madrid, 1881.

Diez De Axdino (D. Julian).

Cartilla de selvicultura.-Santander, 1860.

Escosera y Coronei (D. Luis de la).

Mannal del capotaz de cultivos.--Madrid, 1877.

La Phyloxerc.-Madrid, 1878.

Breves consideraciones scbre estaiica quimica forestal.--Madrid, 1879.

Escrirano y Perfz (D. Jose Maria).

Pamona de la provincia de Murcia. Memoria premiada por la Teal Academia de Ciencias.-Madrid, 1884.

Fenech y Artells (D. Antonio).

El volo particular del Sr. Moret.-Pontevedra, 1883.

Los montes publicos de Galicia. Memoria premiada por la Sociedad de Juegos florales de Pontevedra.-Madrid, 1884.

\section{Garcia Maceira (D. Alitonio).}

La agricultura salamantina; sus males y sus remedios.Salamancai, 1871.

La cana de azucar.--Madrid, 1875.

Apuntes y noticias sobre la agriculturu de los arebes espanoles. -Silimanca, 1876.

Beneficion de las aves insectivoras. Obra premiada en concurso publico-Madrid, 1882.

Estudio de la invasion en los montes de la provincia de Salamanca del insecto llamada vulgarmente Lingartu.-Madrid, 1885.

Leyendas salmantinas.-Madrid, 1885 y 1886.

\section{Garcia Martino (D. Francisco).}

Historia y literatura de la ciencia forestal en Alemania.Madrid, 1869.

Consideraciones economicas sobre la propiedad forestal._Madrid, 1869.

L'n problema de la ciencia de montes,--Madrid, 1869. 
Memoria sobre los trabajos ejecutados por la Dirccion general de Estadisticr.-Madrid, 1870.

Los montes y el Cuerpo de Ingenieros en las Corles Constitu yentes.-Mudrid, 1871.

\section{Huceja y Rosicho (D. Javier).}

Manual de entomologir.-Dos tomos.-Madrid, 1881 y 1882. Influencias del arloblado.-Madrid, 1883.

\section{Jurdana Y Morera (D. .José).}

Apuntes bibliografico forestales. - Madrid, 1875.

Los montes y la colonizacion en Anstralia. Tasmania y Nneva Zelanda. En colaboracion con D. Juan Morphy.-Madrid, 1878. Apuntes sobre los montes y la agricultura norteamericana. En colaboricion con D. S. Vidal.-Madrid, 1878.

La agricultura, la industria y las bellas artes en el Japon.Madrid, 1879.

La agricultura y los montes de los Estados Unidos.-Madrid, 1880 .

La produccion agricola y forestal de la Argelia. En colaboracion con los Srs. Madrid-Dávila y Robles. - Madrid, 1882.

Notas sobre los alcornocales y la industria corchera de la Argelia.-Madrid, 1884.

Curiosidades naturales y caracter social de los Estados Unidos. Madrid, 1884.

El Monasterio de Piedra visto al natural.-Madrid, 1885.

Novelas norteamericanas (tramslated from the English).Madrid, 1885.

\section{Jordaxa y Murelia (D. Ramón).}

Memoria solve lit produccion de los montes publicos de Filipinos en el ano economico de 1871-72.-Madrid, 1874.

Idem de 1872-73.-Madrid, 1874.

Idem de 1873-i4.-Madrid, 1876.

Idem de 1874-75 y 1875-76.- Madrid, 1879.

Munual de la cria de animales domesticos.-Madrid, 1882.

Manzal de podus e ingertos de artoles frutales y furestales. Madrid, 188:.

Bosquejo geografico e historico-natural del Archipelago filipino. - Madrid, 1885.

Guia del viajero de Barcelona a Manila por el canal de Suen. -Madrid, 1886. 


\section{Laguna y Viljaxueva (D. Máximo).}

Itemoria de reconocimiento de los montes de Sierra Bullones pertenecientes a Espana.-Madrid, 1861.

Nemoria de reconocimiento de la sierra de Guadarrama bajo el punto de vista de la repoblacion de sus montes. -Madrid, 1864.

Lxcursion forestal pos los Imperios de Austria y Rusia.Madrid, 1866.

Resumen de los trabajos verificados por la romision de la flora furestal Espanola. Dos tomos.-Madrid, 1870 y 1872.

Un neuvo roble de la flora de Filipinas. - Inidrid, 1875.

Discurso leido ante la Real Academia de Ciencias exactas, fisicas y naturales. -Madrid, 1877.

Coniferas y amentrceas espannolus.-Madrid, 1878.

Cien helechos de Filipinas. - Madrid, 1878.

Un mesto italiano y varios mestos espannoles.-Madrid, 1881.

Que son las plantas. - Madrid, 1883.

F'lora forestal espanola. Con un atlas de 50 laminas cromolitografiadas. - Madrid, 1883.

Caracteres de la flora Espannola.-Madrid, 1884.

\section{Leon del Rivero (D. Roque).}

Memoria de ordenacion de la Reales Matas de Valstin.Madrid, 1886.

\section{Llaurado y Fabregas (D. Andrés).}

Tratado de aguas y riegos, Dos tomos.-Madrid, 1886.

\section{Montes y Perez (D. Victorianu).}

Dictamen sobre la scausas que influyen en lus continuulus sequiras que experimenta la provincia de Almeria y medios que tenderian a corregirlas.-Madrid, 1879.

\section{Munoz de Madariaga (D. Juan José).}

Lecciones de petrografia aplicada.-Madrid, 1878.

Manual de mineralogia.-Madrid, 1880.

Manual de geologia-Madrid, 1881.

Lecciones de quimica aplicada.-Madrid, 1886. 
Navarro Reverter (D. Juan).

Del T'uria al Danubio: Memoria de la Exposicion universal de Viena._Valencia, 1875.

\section{Olazabal y Altuxa (D. Lucas).}

Suelo, clima, cultivo agrario y forestal de la provinia de Vizcayo. Memoria premiada por la Real Academia de Ciencias. -Madrid, 1857.

Proyecto de ley de montes.-Madrid, 1877.

Ordenacion y valoracion de montes.-Madrid, 1883.

Sobre la desamortizacion de los montes publicos proyectada por el Sr. Camacho.-Madrid, 1884.

\section{Parada y Barreto (D. Adolfo).}

Claves dicotomicas para la determinacion de los tipos, clases, ordenes y familias en los reinos unimal y vegetal - Madrid, 1870.

$$
\text { Pakdo y Morexo (D. Eduardo). }
$$

A puntes sobre el esparto.-Madrid, 1865.

\section{Pascual (D. Agurustin).}

Estudios forestales.-Madrid, 1852.

Resenna agricola de Espana se publico en el Anuario de Es:adistica correspondicute a 1858. - Mudrid, 1859.

Intorme de la Juntu Facnl iva d. l Cuerpo de Ingenieras de IIontes con motivo do la elsamertizacion forestal. - Madrid, 1855.

Sobre el vocablo forestal. - Madrid, 1869.

Sisttmas forestales.-Madrid, 1870.

Discurso leido ante la Real Academia Espanola.-Madrid, 1870.

\section{Pla y Rave (D. Eugenio).}

Maderas de construccion naval.-Madrid, 1875.

Marcos de maderas paras la constraccion civil y nuval.Madrid, 1879.

T'ratado de maderas de construccion ciril y naval.-Midrid, 1879.

Manual de cultivos agricolas.-Madrid, 1879.

Mannal de cultivo de arboles frutales y de adorno.-Madrid, 1880. 
Manual de cultivo de arboles forestales.-Madrid, $18 s 0$.

Manual del moderero.- Madrid, 1882.

\section{Puig y Valls (D. Rafaél).}

breves consideraciones sobre la importancin industrial, minera, ajricola y forestal de la alta cuenca del Llobreyat.-Madrid, 1881.

$$
\text { Romero y Gilsaxz (D. Felipe). }
$$

Articulos sobre una cuestion de montes.-Valladolid, 1883.

\section{Ruiz Amado (D. Hilarión).} 1859.

Manual de legislacion y administracion forcstal.-Geroua,

Estudios forestales: Los monte en sus relaciones con las necesidacles de los pueblos, Dos tomos.--Tarragona, 1870 y $1<\tau 2$.

Tablus taquimetricas.-Barcelona, 1885.

\section{UgaLdezubiauR (D). Santiago).}

Memoria descriptiva de la provincia de Manila.-Madrid, 1880.

\section{Vidal y Soler (D. Domingo).}

Manual del maderero en Filipinas.-Manila, 1877.

La flora fil pino agustiniana.-Manila, 1877.

\section{Vidal y Soler (D. Sebistiáiı).}

Memoria sobre al ramo de montes el la Islas Filipinas.Madrid, 1874.

Apuntes sobre los montes y la agricultura norteamericuna. Ein colaboracion con D. J. Jordana,-Madrid, 1878.

Catalogo metodio de lu plantas lenosus silvestres y cultivalas observadas en la provincia de Manila-_I:

Resena de la flora del Archipelago filipino.-Manila, 1883.

Sinopsis de familias y generos de plantas lenosas de Filipinas. Con un atlas de 100 laminas.-W:unila, 1883.

Phonerogame Cumingiunce philippinarum -Manila, 1885.

Xerica e Idigoriss (D. Rianól de).

La teoric y la practica de la resinacion.-Wadrid, 1869. 
In this list is included a volume, which was printed in 1873, not for sale, but for distribution, by Don José Jordana y Morera, to which reference has areadly been made as a Catalogue Raisonné, of upwards of eleven hundred books, manuscripts, maps, and charts, bearing upon forestry and forest science, which had been published in the Spanish language. It is entitled Apuntes Bibliographico Forestales, o sea breve resumen do los Libros, folletos, articulos, impressos, manuscriptos, mapas, planos, y demas trabojos originales o traducidos, por Autores Fispandes, relativos a la cria, cultivo aprovechamiento administracion, legislacion y economia de los montes, armolados, plantios, prados. caza y pesca-Forestal Bibliographic Notes, or short resumés, of books, pamphlets, papers, short treatises, manusuripts, maps, charts, and other original works, or translations, by Spanish authors, relative to the creation, cultivation, exploitation, alministration, legislation, and cconomy of forests, woodlands, plantations, meadows, the game, and fisheries.

The list comprises works published previous to 1860 . By Senur D. Rafael Alvarez Sereix, now of the Government Department of Statistics and Geography, there was prepared and printed a list of works on forest science, published in Spain between the years 1860 and 1881; and he has since prepared a list in manucript of works published since 1851 to the present time. In these a ppear most of the works included in the foregoing list of works published by members of the Corps of Forest Engineers. 


\section{CHAPTER V.}

\section{FOREST EXCURSIONS.}

At Villaviciosa there were many local advantages enjoyed by the students engaged in prosecuting their studies, and there was formed a campo forestal for their benefit. This took much of the character of an arboretum, in which the students inight familiarise their minds with the labits of different kinds of trees, acquire some knowledge of the general appearance and natural history of these; and acquire some experience in planting, transplanting, and sowing. But there was no campo de practiros in which they could be exercised in any way in forest management; nor was there in the immediate vicinity extensive forests, in which a practical kno.sledge of what is called in Spain Forest ordinacion, or the scientific arrangement of partitions, and of forest exploitations, might be gained. This made it more easy to secure the acquiesence of all concerned in the removal of the school to the Escurial when that was carried out, though, as has been indicated, this was resolved upon on other considerations.

Within the domains of this spacious royal palace there existed formerly pine woods of considerable extent, but these unhappily had been sold, and were being so devastated as to threaten their entire destruction. There were ceded to the echool the forests of the Herraria and the Romeral, that in these might be established for the school its own field of operations; but these forests did not admit of the end designed being gained without studies in the replenishing of exhausted forests, and this it was impossible, through lack of mean;, to effect; and the furests had been so badly treated that for their restoration it would be absolutely necessary to suspend 
all exploitation beyond that of depasturing such portion as was adapted for this, to the prevention of that mode of carrying out felliugs in the localisation and practical execution of which the students would have found profitable instruction. Still there were some advantages accruing to the school from having possession of these properties-advantages the loss of which was painfully felt when the park of the Casita de Arriba, which had been at first placed at the service of the school, was afterwards withdrawn, and hat been for some months under the administration of the Royal patrimony, whicb at the end of the year freely disposed of the improvements which they found carried out in it.

The Casita de Arriba is a mansion surrounded with umbrageous grounds, situated little more than half a mile from the school. It was erected in 1772 by the Infanta D. Gabriel, and was granted to the authorities of the schoul to supply the place of the campo forestal, or arboretum, at Villaviciosa. The grounds were of such extent as to afford facilities for the students being exercised in the sowing and planting of trees, aud being made acquaiuted with the operations and requirements of sylviculture. But the shortness of the time in which it was so used, from 1870 to 1876 , did not allow of a great deal beiug done in the development of it as a exercise field, and when embodied in the Royal patrimony the authorities of the school ceased to have the administration and use of it in forest management; and the privation was felt by them. But there are a number of trees growing in the entrance court of the school; and in a neighbouring street is a campo forestal in which the students are exercised in nursery work, but this is limited in extent, and the school was reduced in this respect to a condition not greatly dissimilar to that under which it had been placed at Villaviciosa; but it was not worse. The students still had access to the celebrated pine forests of Valsain, though these were at a distance, and thither they could be takeu in spring, on excursions of observation, and ex ercised, if it were desired, in operations of practical forestry. 
From the founding of the school, up to the present time, it lias ever been the desire of those taking the deepest interest in it, to raise up a body of able-bodied, strong-minded, well educated, thoroughly trained, and well instructed gentlemen -gentlemen both in the usual acceptance of the term, and in the higher one according to which he gentle is who geutle does,* heartily devoted to their profession, taking a comprehensive view of the range of matters with which forestry bas to do, and able to state distinctly and explicitly in courteous language what in counection therewith they consider the interests of the country require should be done.

His Excellency Senor D. Bernardo de la Torre Rojas, the founder aud first director of the school, in a manuscript work preserved in the library of the school, entitled Apuntes de mi Diaris Purticular Relative a la Fundacion de la Escuela y Cuerpo de Ingenieros de Montes-Notes from my Private Journal relative to the Founding of the School and Corps of Forest Engineers-writing of the importance of combining with the instruction given in the school the practical application of knowledge acquired, and the developinent in the students of an esprit de corps, goes on to say: - 'It is with this in view that I attach so much importance to the development of physical strength in the forest engineers; for I am persuaded that otherwise they will be consiuered and treated as only poor students, devoid of the strength needed to inspire respect in the employes of the department who may be required to accompany them, if they do not on their forest expeditions show themselves to be as strong as they are.

'Discipline,' he adds, 'does not consist, as many others believe, in the simple obedience of the inferior to his superior in what pertains to the service, but it extends to uninterrupted respect in the private intercourse of the classes with each other. The conduct thus spoken of must be based not on the force of prescriptions or 
precepts, which it is so easy to evade, but on the habits of which they see a constant example in the superior chiefs under whom they serve.

'A body without a soul is a galvanised corpse. An isolated individual is nothing; two are some, and three constitute an integer or entirety if they constitute a corps* The esprit. de curps, without discipline, may, however, become a public calarniti. But still I would not feel that I had completed the work I had laid out for myself if I did not embody in this basis the idea at least of a matter of so much importance.'

Citing these statements Senor Castel remarks:'These paragraphs which I quote entire, fearing to weaken in the lcast degree the idea of the founder of our school, it may be seen justify what I have already alleged, that during the period of foundation, and introduction into Spain of what maxy lue called a new science, there could only be made experiments or trials of what hal proved the best methorls of instruction employed elsewhere; and thus it came about that this acquired an eminently pracicical character, corresponding to the uecessities of the time, and the example which it was sought to followthat found in the forest academies of Saxony.

'The studies of topography, which constitued essentially at that time the first year's section of the course to be followed, were prosecuted more in the field than in the class-room ; and such a progress was :nale in carrying out the principle of having the class-room under the open heavens [what in Britain would be called field lectures] that even the examinations at the end of the session were held in the forest of Las Huelgas, near the banks of the Guadarrama.

'Many forest engineers there are who still remember with pleasure the examination held on the 21 st of July, 1848. There was pitched in the locality mentioned an elegant commodious tent, ornamented with the national

" [Scottice.-Ane's nane; twa's some ; three's a pickle ; four's a crum.] 
shield, and the emblems or symbols of the corps. In this met the professors constituting the trilunal, and there, under the uranches of the trees, was exhibited the first authorisation of the formation of a School of Forestry, which was exposed -curious circumstance but apprupriate - on the board of a theordolite.

' $T$ o these field exercises there succeeded in the second year, and the others following, forestal excursions to the forests of the Sierra. With disregard of selfish considerations, both professor and students made the journeys on foot, collecting and discussing as they went all objects possessing any interest with which they met, whether these were plants, or insects, or rucks. The strictest discipline, compatible with perfect and expansive freedom, characterised their whole procedure, even in details; and to maintain the enthusiasm and joviality of the espril de corps there was sounded forch by the youthful students the so called Forest Hymn, cumposed by one of them, and enspirited with the purest love of science, of nature, and of their country. Eighteen years later we, the disciples of these students, sing that same hymn, reproducing it in the pineries of the Cordillera of the Guadarrama, and shouting out with a voice which the echo repeats and extends-

'Al campo marchemos!

Risuenna la aurora,

Las blancas estrellas,

Luciente borro ;

Subid! Peunalara,

De nieve vestido,

Los rayos nacientes,

Kiefleja del sol.

Mirad como brota,

Y baja espumoso,

Banuaudu los riscos,

Torrente veloz;

Y roca tras roca, Uruzando el abismo, La cabra ligera, Naltar sin temor, 
Mirad de los pinos,

Las copas gigantes,

Que mece suave,

El aura al pasar:

Hoy canta en sus ramas,

Amores el ave,

Mannana iran ellos,

Cruzando la mar.'

The verses may be roughly rendered-

We are off for the forest !

The smiling aurora

Effaces with brightness

The white stars of night !

Climb up Pendalara,

Which in vestments of snow,

Reflects clear the bright rays

Of the new risen sun.

See! how yonder bursts forth,

And comes down in white foam,

Filling full its mountaiu bed

The rushing torrent!

While the sure-footed goat,

Crossing that deep abyss,

Bounds from rock to rock

Without tremor or fear !

And afar, the massive crowns

Of the mountaiu pine trees

Are swaying gently

In the passing breezc!

To-day birds in the branches

Sing joyfully notes of love :

To-morrow these are felled

And cross the deep sea!

While one or more sing stanza after stanza-either the same singers or others-all thunder forth a chorus. The chorus may be roughly rendered thus:--

Cotta the learued! Thy children in Spain

Invoke thy name, which is now immortal,

'To their country promising such fruits

As thy genius has produced in Tharand! 
Comrades let us follow the path

Traced out by the hand of Cotta !

Our science will be proved by our work!

Our power will be tound in union.

The song was, and is, a favourite with the students, and I was told that it was constantly sung by them on their excursions to the forests of the Escural and of $\mathrm{La}$ Grainja, in 1847 and 1848.

I have seen a MSS. copy varying somewhat in phrase and measure, but not in sentiment, with a notation of tise air to which it was sung, a strophe being sung in tenor by a single voice, and each verse as an antistrophe sung by another in bass, and then the strophe as a chorus sung by all in tenor and bass in harmony.

The verses I have cited I have heard sung to the air of one of the popular songs of the Revolution.

II. Bourguing, minister plenipotentiary from France to the Court of Maririd in the end of last century, tells in a work published by him on his return to France, that the furms of poetry in Spain are varied to a singular degree; their language, being very easy of inversion, is capable of all sorts of verses seen in modern language, but lhey reckon three as those in general use-blank ver-e without any kiud of rhyme, which differs firom prose only in the number of feet, and the orderly interchange of the long and short syllables; verses with perfect rhyme, which they call consonantes; and what they call asonantes, in which are written almust all their old plays, and many of the modern ones. These commonly, says il Bourguing, begin in a series of true ver'ses, con-onuntes, either in common rhyme, and with equal feet or in alterlate rhyme and unequal measure. After a scene or two, sunetimes ouly a speech or two, comes the turn of the asonantes, which generally last to the end of the piece, nuless in some part the consonates reappear for a little time. These asonantes are a string, often very long, of cadenced phraves subject to a certain measure. Each of them is a verse; 
but the asonante returns only every other line, and makes no rhyme. It is sufficient that the two last vowels are the same. In illustration are given quotations from classic dramas, in one of which sirve and vides; in another tema and era; in another raras and casas, planfas, ancl probanza, are asonartes; and he goes on to say: withont being acquainted with this beforehand, a foreigner might requent the Spanish theatre for years without perceiving the existence or effect of the asonantes; and though he be put into the way he will often have nuch trouble to trace them when he hears them on the stage. But what is so difficult for him to catch at does not escape a Spaniard for an instant, however unlearned he may be. After the second verse of a long string of asonantes he discovers the final vowels which govern; he listens at the proper places, and an actor could not with impunity disappoint him : this is a rare quality, owing to the delicate organisation of the people, and to the liabit of declamation which the most obscure and vulgar acquire. I leare to my realers to classify the song.

In accordance with what I have stated in regard to the usage coming down from what some would call the olden time of $18+7$ and $184 S$, provision is made for excursions to neighbouring forests, and even forests at a considerable distance from the school, being made by the students in company with one or more of the professors -including provision for meeting the expenses of all on such excursions, - and for excursions being made by the professors into the furest lands of other nations for purposes of observation and report.

Uf what may this be done, and has been done, an illustration is supplied by a Report alrealy mentioned, published by official anthority, entitled 'Memoria Relativa a la Excursion Verificada por los Aluminos de tercer Anno de la Escuela Especial de Ingenieros de Montes a los Montes Publicos, Dunas y Alcomocales de la Provincia de Gerona por el Verano de 1\$82, Escrita por Don. 
Primativo Artigas, Ingeniero Jefe de Montes, y Professor de Selvicultura, Meteorologia y Climatologia de la Escuela Especial de Ramo. Publicata con Authorizacion Oficial ' - Memoir relative to the Excursions made by the Students of the third year of the School of Forest Engineers to the public forests, dunes, and cork-tree woods of Gerona, in the spring of 1882 - written by Don Prinitivo Artigas, Chief in the Corps of Forest Engineers, and Professor of Sylviculture, Meteorology, and Climatology in the School of Forestry, and published with official authority.

The report of the tour of observation shows such tours to be made not in a desultory manner, but with some special object to be accomplished, as in this case in fulfilinent of a commission given to the Professor, with authority to take students with him to see what he sees, and learn from him what he may consider it of importance that they should know. The tour was made by an order of the Minister of the State, issued on 8th June, 1882, in fulfilment of arrangements sanctioned by Royal order in the May of the preceding year. It was submitted by the Professor to the Council of the School of Forestry, with explanatory statements, and on their recommendation it was published at the expense of the State.

The report, interesting to us chiefly as illustrative of the kinds of objects to which the attention of the students was directell, comprises accounts of Barcelona, of the large manufactory of land and naval engines there, the carpet manufactory, the saw mills, the ships and shipping, and the public park - with lists of trees, slurubs, and interesting herbs, indigenous and exotic, seen there; of the public forest of the province of Gerona; of an inundation which had occurred, and the need there was for an increase in the staff of officials employed: Of Gerona itself accounts are given of the saw mills; of the manufucture of paper pnlp; of the public park, and trees and plants seen there; the geology of the district; the institution of secondary education; and the Archæological Museum. There are uext 
described the pineries of Palafargell; the lighthouse, and the academy. To this succeeds the accounts of the cork-oak, and the cork manufacture, which has been cited [ante p. 114] and of thedunes on the coast ; of measures adopted for fixing these, with notices of the climate, and of legal questions relative to the proprietorship of these ; a list of 12.5 articles used or produced in the forestal industry of the district, collected and deprsited in the museum of the school ; lists comprising 100 specimens of plants, minerals, and rocks, also collected and so deposited; and a resumé of the whole, with practical and scientific conclusions arrived at.

Passing next to Torroella de Montgri, accounts are given of the mansion and forest La Fonollera; of the dunes of Bagur; of the invasion of the phylloxera in Ampurdan; of the forest Montana Gran, and its management; reasons why the forests of Torella de Montgri should, with other classified State forests, be exempted from sale; of the agricultural productions of the district, with notices of the importance of establishing there a forestal meteorological observatory. To this follows a report of the dunes, which has been reprinted and published in a separate form; in this accounts are given of the dunes of the first, the second, and the third zones; remarks on the fixation of dunes; on the climates of the dunes; opinions relative to the fixation of dunes; a question at law relative to dunes; and there is discussed the question of the appointment of a Commission on dunes, with some account of what has been done in other lands in connection with the fixation of dunes. There follows a catalogue of objects of forestal industries, of plants, of minerals, and of rocks, collected by the students in the course of the tomr, and deposited in the School of Forest Engineers in the Escurial. These lists fill eight pages of large 8 vo.

In article 23 of the Reglamenta of the school is stated: every year one of the professors appointed in turn shall go abroad during the summer, in order personally to see what improvemeuts or additions might be introduced into the 
course of instruction followed in the school; and shall embody in a memoir the results of his observation, which, having been submitted to the council of the school, shall be transmitted by them to the Minister de Fomento. And according to article 30 of the Reglamenta of the school, when the professors prepare memoirs, lessons, or relative treatises, on matters comprised in the course of instruction, or in the programme of preliminary examination, they are entitled to special grants in remuneration on a proposal to that effect of the Junta Facultative of the corps, on the previons report of the professors. The amount of the remuneration is determined by the Government.

Such a tour of observation was made in 1864, by Royal order of the King of Spain, by Sr. Don Maxima Laguna y Villanueva, Forest Engineer in Chief, and Professor in the School of Forestry in the Escurial. The report made by him, published in 1866, by Royal order, treats of the instruction in forest science and practical forestry in Austria in the schools and acadomies of Mariabrunn, Schemnitz, Weiswasser, Ausee, and Kreul, comparing it with that given in Villaviciosa in Spain; and suggesting certain modifications in this deemed likely to be useful. It discusses also the forest service in Austria, in Bohemia, in Hungary, and in Saxony, together with the instruction in forestry given in Russia, and in the School of Practical Forestry in Lissino, and in those of the Steppes; and the goneral administration of forests in Russia.

Senor D. Carlos Castel y Clemente, Commander of the Order of Isabel la Catholica, and Chief of the Second Class of the Corps of Forest Engineers, made a tour through Norway and Sweden, and by Royal order the observations submitted by him to the Facultative Junta, or Council of the Corps, were printed in an edition of 600 copies, under the title 'Memoria sobre las condiciones naturales y produccion Agricola y Forestal de la Peninsula Escundinavia.' Under successive chapters there are detailed the gengraphic conclition of the Scandinavian 
Peninsula, embracing:-1. The situation, boundiaries, and area; the geography, and the hydrography of the land. 2. Factors of production: the soil, climate, and people. 3. The agricultural production, with details of the different botanic regions, and of agriculture. 4. The forests, comprising the mode of tenure by which they are held, and the condition and products of the forests. 5. Furest industries, embracing the transport and sawing up of timber; the fabrication of wood pulp; of charcoal, and of lucifer matches; and other products of the forests.

On the occasion of the International Exhibition in Philadelphia being held in Pennsylvania, again Senor Don . José Jordana y Morera, Chief in the Corps of Forest Engineers, author of the 'Catalogue Raisonné of Spanish Works on Forest Science,' of which mention has been made, was sent as a commissioner and director of the agricultural department of Spanish exhibit;, and Senor Don Sebastian Vidal y Soler, Chief in the Corps of Forest Engineers in the Phillipine Islands, and official in the order of the royal crown of Prussia, as commissioner from the Minister of foreign affairs, and by them a report was made under the title of 'Apuntes Sobre los Montes, y la Agricultura Norde-Americana, Memoria Elevada al Exmo. Sr. Ministro de Fomento'-Notes on the Furests and Agriculture of North America : a Memoir submitted to the Minister of Agriculture, Public Works, Trade, and Commerce-which was published in 'El Tiempo,' and in the 'Boletin Oficial del Ministerio de la Ultramar'-Foreign affairs; and subsequently reprinted and published for general use.

In this there are given reports of the boundaries, area, orography, hydrography, geclogy, geognosy, temperature, and rainfall of the territory of the United States; which is followed by a lengthened review of the forestal condition of the country throughout its extent, based on data obtained from the work by Professor Brewer of Yale College, Newhaven, and the statistical atlas of General Walker, It 
comprises:-1. Prevalent ideas on forestal matters, as advanced by distinguished writers, and by scientitic sociecies. 2. Forestal legislation in regard to the Union and to individual States. 3. Instruction given to officials, and methods of management followed in the existing forests. 4. A forestal sketch of the country, specifying the wooded areas, and the kinds of trees growing. 5. Sylvicultural conditions of such species as might be introduced advantageously into Spain. 6. Forest industries, more especially those connected with the trade in timber, and the exploitation of resinous products; and an account of maps and works and forest products which might be useful in the instruction given in Spain, which they had collected. This is fullowed by a more coudensed review of the agriculture of the United States, in which are tabulated the respective money value of the several agricultural products of the country, and of the different kinds ot animals reared and tended; the population of the different States; aud the number of bushels of maize raised in each, with the number of bushels of wheat to each inhabitant; the value of cottun raised ; the value of the aunual production of sugar during the preceding five-and-twenty years in the State of Louisiana and throughout the United States; and in conclusium there are enumerated as deserving of study:-1. Special articles of culture: ccreals, roots, forage plants, tobacco, sugar cane, and rice, with the adaptation of the first mentiuned three for culture in the Peninsula, and the remainder in the foreign dependencies of the country. 2 . Implements, apparatus, and machines for the inprovement of culture, and subsequent preparations of the aforementioned, according as the produce is required for the market, or for agricultural reproduction. 3. Systems of breeding and rearing cattle, and the best breeds for draught, and for the production of flesh, wool, milk, and leatler. 4. 'The principal schools of agriculture, and methouls of instruction followed in these. 5. Works, maps, and agricultural works of all kinds which might be of benetit for Spain. 6. An agricultural and pastural sketch of the United States. 
In the spring of 1881 there was held in Algiers what in Britain would be called an Agricultural Show, the comprehensive character of which led to considerable importance buing attached to it by those living in Northera Africa and elsewhere, who were desirous of becoming acquainted with the agricuitural capabilities of Algeria, and the development which these had received 'The Government of Spain commissioned again Senor D. José Jordana y Morera, Chief in the Corps of Forest Engiueers; Senor D. Alfre o de Madrid Davila, mining engineer ; and Senor D. Eduardo de Robies, agricultural engineer, to attend, make their observations, and report. Every facility they could desire was afforded to them by the authorities in Algiers. The Exhibition continued from the 2ud to the 11th of April. On the 14th there was assembled a Congress of Science, which was continued till the 20th; after which several scientific excursions, for which preparations bad been made, were undertaken by the members of the Congress. This was attended by the Spanish Commissioners; and these giving their attention chiefly to matters pertaining to agriculture and forestry, availed themselves of the arrangements made to visit, and reconoitre with the greatest extent and precision possible, the Cedar mountains of the Atlas range; the agricultural exploitations of Bouffarik: the fruit cultures of Blida; those of the Huerta of Perregnes; those of the secano, or dry arable land of Sidi Bel Abbes; and the system of irrigations and pantanos or reservoirs of the Cuenca, or basin of the Habra.

Their report comprised, with a critical account of the Exhibition, a detailed description of the agricultural and forestal cultures, of the cattle stock, of the tixed property, and, in a word, of everything constituting the territorial strength of that fertile country. It was illustrated by numerous drawings, and accompanied by a detailed account of the excursions and professional visits of inspection made by the several members of the Commission to estates and districts remarkable in connection with some of the 
matters interesting to agriculture; with interesting an I useful statements of comparisons between the agriculture of Algeria and the agriculture of Spain, and recommendations of innovations by which the productions of Spanish lauds might be improved. By the Government it was recognised that the report by the multiplicity of matter's which it embraced, and the character of its details, constituted it an excellent agricultural and forestal description of Algeria, such as was not to be found in the Spanish language, if such an account of that country existed in any language; and it was by Royal order published at the expense of the Ministry de Fomento, mucler the title of " La produccion Agricola y Forestal de la Argelia en el Concuso de Argel de 1S81-The Agricultural and Forestal Productions of Algeria in the Colonial Exhibition in Algiers in 1881. In an introduction is given an account of the country; and there is added a list of the more important of the works, printed looks, painphlets, an't periodicals made use of by the Commissioners in the preparation of their report, constituting a valuable bibliography of Algeria. Details are given of agricultural exploitations in different parts of the colony, and of the works of irrigation; descriptions of the cattle, oxen, sheep, and goats; of asses, mules, and horses; of camels, dromedaries, and swift úromedaries, mehuris; of poultry and domestic animals under acclimation; accounts of machinery, implements, and tools, includirg hydraulic apparatus, steam engines, and wiud-mills; detailed notices of agricultural and forestal products, aud industrial manufactures connected with these, including sericulture, apiculture, pisciculture, \&c., horticulture, arboriculture, the culture of the eucalyptus, and that of the cork tree, and the collecting of esparto grass; and agricultural and forestal maps of Algeria, including charts of the orange producing region, of that of the vine and the olive, of the zone of the esparto grasses, and of the so-called wer d'alfa.

In further illustration of the breadth aud compreheusive. 
ness of views taken in Spain in regard to what should be done under the provision made in the Reglamenta of the school for excursions in foreign lands, such as have been mentioned, I may state that a commission was given in accordance with a Royal order to a member of the Corps of Forest Engineers, Senor D. Joaquin Maria de Castellarnau $y$ de Lleopart, to visit the zoological station at Naples, study proceedings there, and report. 'This he did in a memoil' entitled 'La Estacion Zoologica de Napoles y sus Procedimientos par el Examen Microscopico,' which was presented to the Minister / Fe Fomento, the Minister of Agriculture, Trade, and Commerce, and published.

Senor Castellarnau spent at the station the first three months of 1883; and in his memoir he sought to give a definite and correct idea of the station, of the facilities for study afforled by it, and of the importance, and eveu necessity, which there is for such stations, if zoology is to be made a true science founded on observation; and thereafter to discharge the commission with which he had been entrusted, by describing the methods and special proceedings at the zoological station at Naples, omitting all sucl generalities, formulas, and modes of operation as may be met with in treatises on the microscope, but narrating some which might not have been previously described.

In the first part is supplied information relative to the necessity, the object, and the importance, of such observatories; the history of this zoological laboratory, in which there are 22 tables, supported by different nations, including one supported by the British association for the advancement of science, where any one nominated by the association may prosecute researches; and two were formerly supported by associations in the United States of America, at one of which a young lady was then engaged in the study of cephalopods;-publications which had appeared communicating the results of observations male; neans which had been adopted there and in other countries for the preservation of marine animals; and the ayuarium of 
the station. And with this information is given a detailed account of the fauna of the Gulf of Naples.

In the second part there is given copious, explicit, and valuable information, such as might be desired and found satisfactory by any parties desirous of establishing a similar institution, or deciding on the expediency of proceeding thither for study of the protozoas, both general and special, and in regard to proceedings followed in the study of marine animals in general : first, proceedings connected with the killing, setting, and preservation of these; and the application made of these to the different classes-protozoas, sponges, and corals, the actinex or sea anemones, and madrepores, the medusæ, \&c., \&c., the crustacex, the molluscs, and the vertebrates; operations connected with dissection, with colouration, and with making and mounting sections. In an appendix there is given information in regard to photo-micrography; and in each section there is given the billiography pertainiug to the suhject.

By the Minister De Fomento the report was subuitted to the Junta Facultaive de Wortes, or Forestal Professional Council, in accordance with the regulation cited. By them its publication and distribution among personsand establishments dedicated to the study of natural sciences was cordially recommended. In their report they enlarge on its relating chiefly to study of the aquatic protozoa, but recognise the bearing of a knowledge of the natural history of these on the natural history of all higher organised structures, animal or vegetable; and thus they indicate the comprehensive character of the views entertained by them of what is comprised in forest science. 


\section{CHAPTER VI.}

CORPS OF FOREST ENGINEERS AND STAFF OF TEACHERS.

By the Revista de Montes there was published an Escalafón, or classified list of the members of the National Corps of Forest Engineers, arranged according to their rank, on the 1st July last (1886).

In an appendix to this it is stated that the title National Corps of Forest Engineers is given to the Association of Engineers, so designated, who have charge of the conservation, replenishing, improvement, and exploitation of the public forests of the kingdom.

By Royal Decree of the 17th of March, 1854, there was created this Corps of Forest Engineers, for the facultative or professional service of the department; and it was arranged by Royal Decree of the 16th March, 1859, that this should be composed of three inspectors-general; fifteen district inspectors; forty chief engineers of first class; fifty chief engineers of second class; sixty engineers of first class; seventy engineers of second class.

According to article 14 of the organic regulations of the Corps, it is obligatory on the Engineers to make use of their distinctive badges in acts of service, and of their uniform in solemnities and public acts in which they are required to take part.

There is also a subaltern service, composed of 25 assistants of first class, and 350 assistants of second class, and of 400 foremen planters, created by the law of 11 th July, 1877.

The custody of the public forests is entrusted to the civil guard. 
From what is stated in this appendix to the Fscalafon, it appears that the School of Forest Engineers at the Escurial is governed by the regulation of 27 th October, 1879 . It was in the summer of 1885 that I visited Spain. In the account of the School, which I have given in a precerling chapter, I have stated [ante p. 20]-'By the Decree of 23rd October, 1868, the prescribed course embraced a period of three years; by the Decree issued under date of 24th Uctober, 1870. it was so extended as to einbrace a period of four years; but by a temporary or provisional arrangement it is at present completed in three years.' And again [ante p. 24] - "The second period of study embraces four years spent in the School,' and the studies assigned to each have been detailed. And according to the statement in the appendix to the Escalafon, in the re-organisation of the School on the 18th August, 1847, the course of instruction embracel four years. I have never heard of any Royal order, or other act, anthorising a change; but it appears from what is sulusequently stated here that at present the curriculum extends over five years.

In accordance otherwise with what I have stated, to enter as a student the aspirant must pass an examination in arithmetic, elemontary and higher algebra, rectilinear and spherical trigonometry, physics, and the French language; and he must present a certificate of academic examinations in geography, history, Spanish, and Latin, or grammar. The instruction in the School is now distributed thus:- First year, descriptive geometry, differential and integral calculus, theoretic mechanics, and general chemistry. Second year, topography, applied meshauics, zoology, and applied chemistry. Third year, botany, mineralogy, geology, and geodesy. Fourth year, sylviculture, meteorology, and climatology, administrative justice, and legislation relative to forests. Fifth year, ordenacion of furests and xilometry, forestal industries, and political and forestal economy; and throughout all the years of study there is continuous instruction in drawing. 
Having concluded their studies, and spent some time in practical work in a forestal district, the students then receive the appointment of forest engineer.

The salaries of the six grades of forest engineers are respectively $12,500,10,000,7,500,6,500,5000$, and 4000 pesetas or francs. In field work the inspectors have also an allowance of 25 francs a day; chief engincers one of 20 francs; engineers of first class and second class one of 15 francs or pesetas.

Spain is divided into 46 forestal districts; three less than the number of provinces and departments. The forests in each of these are under the charge of a Chief Engineer. Besides the forestal district court there is a Junta Facultativa, or Professional Council, composed of eighteen inspectors; the Commission of forestal flora; that of a forestal map, and another of the catalogue of forests reserved from alienation; one of replenishing exhausted forests; and one of the Sierra de Guadarama.

For conducting the studies in the School there are appointed a Director, who is head of the school; ten professors of the corps of engineers; two assistants, who must also be engineers; and to these are joined the following subordinates:-a collector, preparer, and conservator of objects of natural history; an official assistant secretary; an official assistant librarian; two clerks; a steward; a resident in charge of the school forest; a porter ; three servitors; necessary warders and sub-warders for the protection of the land and mountains appropriated to the service of the school; and labourers and peasauts required for work on the same.

The professors, previous to appointment, must each bave completed five years of active service in the Corps of Forest Engineers ; the assistant professors must have completed two years of such service; and of the Director of the School it is required that he must have attained to the position of an Inspector in the corps.

They all continue to receive the salary attached to their 
positions in the service, and with this an annual allowance determined by the Government, with a definite increase at the termination of every period of five yearsservice, continued annually during the next period, the successive augmentations being equal in amount to half the allowance made during the first five years; and should the requirements of the service at any time interrupt the discharge of the duties of the professorship, either during the currency of one quinquennial period or between two, as may happen, this takes place without detriment to the right acquired by previous service in the School; and the Director of the School receives in addition to his salary, as Inspector of Forests, an allowance determined by the Government, in accordance with the same rule as to increase.

Of the officials, the Director and the janitor alone reside in the school buildings.

From the Budget of the $\mathrm{Vinister} D e$ Fomento for 18811882, the latest to which I had access, it appears that at that time the gratuity to the director was 2000 pesetas; to one professor, a member of the Corps, 2000 ; to ten professors, $1500=15,000$; to two assistant professors, $1500=3000$; to the collector, preparer, and conservator of objects of natural history, were paid 2000, and as a gratuity to the same for special work, 250 ; to the secretary, a salary of 1500 , and a gratuity for special work, 750 [sic] 1750; second secretary, 1250; and to a consierge, 1500 ; a porter, 1000 ; three lads, 750 each $=$ 2250 ; an overseer of the campo forestal, 1000 ; a watchman of this, 750 : in all, 33,750 pesetas.

To this has to be added the expense of the establishment, which is given as: maintenance of the school buildings, 500 pesetas; expenses of the secretariat, 500 ; the campo forestal, labour, cultivation, plantations, and tools, 2000; three day labourers at 1.50 of days' wage, 821 ; library and collections in the museum, 1000-in all, 4,821: together, 38,750 pesetas or francs.

As has been intimated, the allowance to the Director and to the professors is in addition to the salaries which 
they draw as members of the Corps of Forest Engineers, which varies with their rank in the service, hence it is designated gratificacion, allowance, or gratuity.

The instruction is given (1) by oral lectures and lessons in drawing by the professors; (2) by written exercises, calculations, and analyses on the subjects embraced by these lectures; $(3)$ by the detailer study of the animals, rocks, plants, and forest products preserved in the collections and adjuncts of the establishment; (4) by the practice of topography, land surveying, the study of natural history and orography in the field ; (5) by excursions to the plantations and uountaius.

The school sessions extend, with specified holidays, from the 1st of October of one year to the 31st of May in the year following. Field exercises are included in this session, but according to what may be required in different classes these may be extended over the months of June, July, and Aurrust.

The material provisions for study, as has been intimated, consist of the buildings, lands, forests, nurseries, gardens, and their dependencies, appropriated to the school; the meteorological observatory; the furniture of the institution, a library and collections of charts and drawings ; a laboratory and cabinet of chenistry, with apparatus and reagents; collections and museums of topography, land surveying, and cabinets of illustrations of natural history, of mountains, of mechanics, and of forest industries; the collection of iron implements employed in the practical working of the school lands or in the studies of the pupils; herbaria and collections of plants and of fruits ; and in conclusion, the workshups and machinery, with all the iron tools belonging to these, and the equipnents and arms of the warders and dependents.

The students do not live in the school; but each is required to lodge his address with the secretary of the school, and to keep him iuformed of any change of residence made by him. They are required to supply themselves with all text-books, mathematical instruments, writing and drawing 
implements, and the uniform prescribed to the students; but beyond this I know of no pecuniary charge made upon them. Regular and punctual attendance, studious attention, and respectful and orderly behaviour are enjoined.

Occasional absence, even with consent of the instructor, want of punctuality, inattention, \&c., are punished by deductions from the numerical value attached to the attendance required in order to obtain a diploma at the close of the course ; disobedience, insubordination, \&c., are punished by expulsion, or suspension till the decision of the Government is obtained.

They are not required to have previously engaged in work of practical forestry ; but, as has been intimated, there is provision for this being done where it may be desired, and for excursions being made to forests, under the guidance of one or other of the professors, in the course of the curriculum. On these excursions their travelling expenses are met from the funds of the school, with an allowance of 10 reals, or about $2 \mathrm{~s}$ a day, and the professor in charge has an allowance of 25 reals, a little more than $5 \mathrm{~s}$, for provisions. 


\section{PART II.}

PRACTICABLE ARRANGEMENTS IN ACCORDANCE WITH THOSE IN I'HE SCHOOL OF FOREST ENGINEERS IN SPAIN, SUITABLE FOR A BRITISH NATIONAL SCHOOL OF FORESTRY.

In the session of the British Parliament in 1886, a Select Committee of the House of Commons was appointed to consider whether, by the establishment of a School of Forestry, or otherwise, our woodlands could be rendered more productive. Before this I was called to give evidence in regard to the constitution of Schools of Forestry; when I stated, amongst other things, in reply to successive queries, in substance that there was no one School of Forestry on the Continent of Europe which I could propose as a model for a British National School of Forestry, if such should be orgariised; nor one which I could recommend as a type; but that I considered the School of Forest Engineers in Spain one organised after a type which it might be advantageous to follow, in organising any such School in Britain for the training of officials to administer and manags extensive forests in our colonial possessions, and other similarly conditioned countries.

One difference which may be remarked in the Scliool of Forest Engineers in the Escurial, and others in Centra! and Northern Europe, is that while these generally are in accordance with a system of graded schools there existing and are adapted to a forestal condition of the country, similar, if not identical, in all of them; that in the Escurial is, to a considerable extent, indepen- 
dent of any such organised school system, and is designed to meet the requirements of a state of things considerably different from that which exists in these other lands; and this is a state of things very similar to what I have seen at the Cape of Good Hope, and what I have reason to believe to be existant in others of our Colonies.

It is in view of this that I cited it, not as a model, or as a type to which it is expedient that a National School of Forestry in Britain should be conformed; but as illustrative of the category of schools of forestry, which are desireable amongst the English speaking uations, and Colonies in which modern forest science and appliances might, in accordance with uational school organisations, be adapted to meet national requirements. This has been done efficiently in Spain; and $I$ ain persuacled that mutatis mutandis it miglit be done in Britain, and other lands similarly conditioned. Under this impression I proceed to discuss some of the facilities presented in our country for the execution of such an enterprise; bringing under consideration those which relate to an appropriate site; those which relate to scholastic arraugements adapted to the site recommended-including conditions, curriculum of study, and expense-and those which relate to the creation of forest literature, similar to the modern forest literature of the Continent. 


\section{CHAPTER I.}

APPROPRIATE SITE FOR A BRITISH NATIONAL SCHOOL OF FORESTRY.

THE selection of a site for a National School of Forestry is a matter of considerable importance. The original idea, or one at least which was entertained at a very early period in the considerations of arrangements to be made for the establishment of a School of Forest Engineers in Spain, was that the school should be established in the capital. Difficulties experienced in securing suitable house accommodation for the school in Madrid proved almost fatal to the scheme. To cite the phraseologv made use of, it had become a question of 'io be or not to be? when the discovery was made that suitable accommodation might be obtained at Villaviciosa ; and subsequently the discovery was made that, all things being considered, still more suitable accommodation might be found in the Escurial: and thus was determined the sites successively adopted. Both of these sites were, by what seems like a legal fiction, considered to be covered by the praseology employed in the Royal Decree, which required it to be located in the vicinity of the Court, by which was meant, in the capital.

These locations successively commanded the assent of His Excellency Senor D. Maximo Laguna y Villanueva, by whom, after making himself acquainted with the conditions of Schools of Forestry elsewhere, the location of the school in Madrid had been advocated; and the assent of His Excellency Senor D. Bernardo de la Torre Royas, by whom the school at Villaviciosa had beeu organised; but the original design was that indicated, that the school should be located in the capital, and this was desired because of the educational advantages which could be commanded there. 
In giving evidence before the Select Committee of the House of Commons, I stated in reply to a query put that Edinburgh affords special advantages, and such as are unequalled elsewhere, for the site of a National School of Forestry.

Among the more manifest advantages of Edinburgh as a site for a National School of Forestry may be mentioned the following:-Adjacent to the city is an Arboretum purchased by the inhabitants at an expense, it is said, of

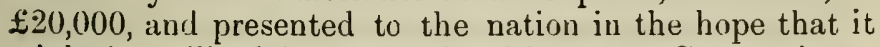
might be utilized for the study of forestry. Conterminous with this, and connected with it, there is a large wellequipped and well-stocked Botanic Garden, supported by the nation. In this there is a large comprehensive museum of all kinds of vegetable products.

In the Museum of Science and Art, maintained by the Committee of Council on Education, in close proximity to the University buildings, there is already a large and valuable collection of woods and other forest products, and well-selected specimens of illustrations of mineralogy and geology, of entomology, ornithology, and mazology; and in the report of this Museum for 1884 it is stated:'Considerable additions have accrued to the forestry section of the Museum from the International Forestry Exhibition which was held in the city during the last year. The whole of the Johore collection of forest products have been presented by His Highness the Maharajah of Johore, G.C.M.G., K.C.S.I., \&c. A large portion of the extensive Indian collections has been received fro!n Her Majesty's Minister of State for India, and an extensive selection of the products of British Guiana, Sierra Leone, Gambia, and St. Vincent, has been given by the Commissioner in charge, the Hon. William Russel. From the Japanese Commissioners to the International Health Exhibition, Messrs Tegima and Nagai, interesting collections of educational objects and food products have also been received.' Nearly three thousand articles were thus added to the Museum. Correspouding collections of articles from 
the International Exhibition, placed at the disposal of a Committee appointed to take measures for the establishment of a permanent Museum of forest products, have been transferred to this Museum by that Committee; and along with these, according to a report made to that Committee, a large collection accumulated during many years by the Scottish Arboricultural Society, all to be arranged for exhibition, so soon as coutemplated additions to the building are made.

There are numerous nurseries in the immediate vicinity of the city, and well-kept woods and plantations of easy access. There is an Arboricultural Society, a Botanical Society, and a Field-Naturalist Club, to the membership of all of which it is presumable students of forestry might be eligible. Thither gravitated the publication of Forestry, a Journal of Forestry and E'state Management; and there are resident the gentlemen with whom originated the idea, and by whom were carried out the arrangements for the International Forestry Exhibition, and those who, from their known interest in the enterprise, have been commissioned to endeavour to secure the establishment there of a National School of Forestry. And there are situated the headquarters of the Highland and Agricultural Society empowered to grant certiflcates of attainments in knowledge of forestry.

In the University are taught the following subjects, by professors whose names are annexed:-MathematicsProf. Chrystal; Natural Philosophy-Dr Tait; Chemistry -Dr C. Brown; Agriculture-Prof. Wallace; BotanyDr Dickson; Geology and Mineralogy-Dr Geikie ; Natural History-Dr J. C. Ewart; Engineering-Prof. Armstrong; Commercial and Political Economy and Mercantile LawProf. Nicolson ; Conveyancing-Dr J. S. Tytler; Anatomy -Prof. Turner; Surgery-Prof. Chiene. In summer, tutorial classes for the study of Mathematics and Natural Philosophy are conducted by the assistants of the professors of those subjects, for students who have attended a winter course therein. 
And means are afforded for practical instruction during winter and summer in the following subjects:-Practical Chemistry, under the superintendence of Prof. Crum Brown; Practical Physiology, under the superintendence of Prof. Rutherford; work in Physical Laboratory, under the superintendence of Prof. 'I'ait; work in Natural History Laboratory, under the superintendence of Prof. Ewart; and in Herbarium and Botanical Museum, under the superintendence of Prof. Dickson. During winterBandaging and Surgical Appliances, under the superintendence of Prof. Chiene; work in Mineralogical and Geological Laboratory and Museum, under the superintendence of Prof. Geikie. In the summer-Practical Botany, by Prof. Dickson; Vegetable Histology, by Prof. Dickson ; Practical Natural History, by Prof. Ewart.

In the Watt Institution and School of $\Lambda$ rts provision is made for the instruction of classes in Chemistry Theuretical and Practical, Natural Philosophy, Mathematics, Arithmetic, Engineering, Architectural, Mechanical, Geometrical, and Machine Drawing, Sanitation, English Language and Literature, History, Animal Physiology, French, German, Agriculture, Botany, Geology, Biology, Freehand Drawing, Bookkeeping, and Writing.

With such provision for preparatory and accessory instruction, all that is further required is provision for professional studies. These may be classed under the following heads :-

Part I.-

Forest botany, cmbracing the structure, physiology, scientific classification, and natural history of herbs found in woods, and arborescent shrubs and trees.

Forest Pathology, or diseases, and the natural decay and death of trees.

Forest Mycology, or natural history of fungi found in forests, and of fungi injurious to trees and timber.

Forest Entomology, or natural history of insects injurious to forest products. 
Forest Ornithology, treating of birds injurious or beneficial to the forests.

Forest Mazology, treating of quadrupeds, \&c., injurious to forests.

\section{Part II.-}

Destruction of Furests by Man.

Forest Conservation in France and in Germany.

History of Forestry.

Advanced Modern Forest Economy.

Sylviculture in accordance with the Advanced Modern Forest Economy.

Forestry of different Countries on the Continent of Europe.

Forestry and Arboriculture of Britain.

Improved Forestry in India.

Treatment of Forests in British Colonies.

Destruction, Conservation, and Extension of Forests in the United States of America.

With many, the proximity of a forest in which students may be familiarised with practical work, is considered necessary to the efficiency of a School of Forestry in Britain. Such an adjunct has not been found necessary in Spain; but no one will deny that it might be advantageous to any School of Forestry to liave such an adjunct.

In the number of the Journal of Forestry for December, 1880 , reference is made (p. $4 !)(\mathrm{i})$ to the proprietor of an estate in Midlothian being willing to fen to the Government, at a low rate, a highly eligible an I conveniently situated piece of land, stretching from the environs of Eilinburgh to the top of the Pentland Fills, for experimental purposes in arboriculture, agriculture, and horticulture. It is stated that the land in question comprises a great diversity of soils and aspects, suitable for the growth and cultivation of all kinds of trees, and a burn, or watercourse, which affords a plentiful supply of water, 
and which could easily be made to form a highly attractive as well as useful object in the landscape. It is stated, further, that it presents a considerable range of altitude, rising from about 200 feet above the level of the sea to a height of about 1,600 feet.

In some of the Schools of Forestry on the Continent the students remove with their teachers to some forest at a distance in spring, and spend the summer in practical work. I do not suppose that any difficulty would be experienced in finding foresters of established reputation willing to supply practical instruction in the forests under their charge to students who were able to avail themselves of such an advantage; nor is it impossible that satisfactory arrangements might be made for such practical training being obtained in some of the Crown forests in England.

By Mr Mackenzie, superintendent of Epping Forest under the Corporation of the City of London, there was submitted to the Epping Forest Committee of the Court of Common Council in 1881, a memorial, in which he unfolded a scheme fur the establishnent of a School of Forestry in connection with that forest. There appears to be little probability of effect being given to his suggestion; but there is one point in regard to which he makes some important statements, of which advantage might be taken in endeavours to secure practical training for students who have no access to forests in Scotland in which to gain a knowledge of the practical work in which they desire to engage.

Writing to the Epping Forest Committee of the London Court of Conmon Cotincil, he says: 'You possess about 6000 acres of land all more or less forest, neglected, detached, and inharmonious in effect by reason if its laving been, from circumstances well known to youl all, so very much subdivided, that an effort must be made, as soon as the outlying portions are restored to your care, to blend them all into one harmonious, albiet diversified, whole; consequently the land must be carefully surveyed, and mapped out accurately, in order that a reliable plan 
may be obtained on which to work out a scheme which may guide the conservators of the forest for all time ; and lastly, that much planting, and the careful thinning and prunning of existing trees, must be judiciously prosecuted for many years.' It is added: 'The execution of all these works would form the best possible groundwork for the practical training of the foresters in the future.' And in the programme of study which he submits, he says: 'If the course of study should extend over four years, the first two to be spent at Epping Forest, where the trees have been neglected for so many years, it will be the object of the staff to organise order, and produce regularity out of disorder and chans; the third year should be spent in the New Forest, which is a tract of sufficient extent, having over 60,000 acres, and which, having been in Government keeping, may be supposed to be a farther advance and development of the principles pursued ly the student during his first two years at Epping; the fourth year should be spent at Windsor, where may be seen the full development of the principles cornmenced by the student at Epping. After this course of training, those pupils who have diligently applied themselves to their studies during the four years should be drafted off to other fields of usefulness, either at home or abroal.'

Should it be deemed desirable, as I think it is, that provision be male for still bigher or more varied training being giren to a select number of the more promising students, the desideratum can be met. In more than one of the most celebrated Schools of Forestry on the Continent, provision is made for the attendance of foreigners, and these enjoy all the educational advantages of the alumni un specified terms. Assuming that the teacher of Botany-if there be but one-or one of them, if there be more, le qualified by knowledge of the language spoken, such advanced students might be sent under his direction to attend at one of these Continental Forest Schools for a summer session; and possibly permission might be obtained from the same or some other School of 
Forestry for the British students to accompany the students of that country on their autumnal excursion, and to take part with them in the forest work, to the great advantage of teacher and taught, and through them to that of the country at large. 


\section{CHAPTER II.}

SCHOLASTIC ARRANGEMENTS.

\section{Section 1.-Conditions.}

Supposing Edinburgh selected as the site of a National School of Forestry, there are four practical arrangements by any one of which the advantages derived from this selection might be secured at a moderate expense:-1. The creation of a Professorship of Forestry or Forest Science in the University. 2. The creation of a Lectureship on Forest Science in the Watt Institute. 3. Ttre creation of such a Lectureship in connection with the Royal Highland and Agricultural Society of Scotland. 4. The creation by the Science and Art Department of the Committee of Council on Education of a School of Forestry in Edinburgh, resembling the Royal School of Science in Dublin, and the Royal School of Mines and Practical Geology in London.

In the Normal School of Science, and Royal School of Mines and Practical Geology in London, under the Science and Art Department of the Committee of Council on Education, instruction was given in the winter session 1883-84, the latest of which I have a report, in chemistry, physics, mechanics, \&c., mathematics, geology, and mineralogy, biology, botany, metallurgy, mining, agriculture, and astronomy. In the summer course of 1884 instruction was given to students in chemistry, mechanics including mechanical drawing, heat, metallurgy, hygiene, and agriculture; and lectures were given to working men in mineralogy, mechanics, and chemistry.

In the Royal College of Science in Dublin, under the Science and Art Department of the Cummitter of Conncil 
on Education, instruction was given in the same session, (1883-84), to students of the first year in pure mathematics, elementary mechanics, descriptive geometry with lessons in geometrical drawing, theoretical chemistry, and experimental physics. To students of the second year instruction was given in pure mathematics, general mechanics, mechanical drawing, practical physies, practical chemistry, biology, and mineralogy. To students of the third year instruction was given in mechanism and thermo-dynamies, applied mechanics and hydro-dynamics, enginecring, drawing, surveying, geology, palæontology, mining, metallurgy, applied chemistry, assaying and analytical chemistry ; and there were special courses of instruction given in hotany and practical botany, and in zoology and practical zoology.

The total number of individuals who attended the stated lectures was eighty, of whom twenty-nine were associates, students prosecuting the whole three years' course with a view of obtaining the diploma of associate. The corresponding numbers in the preceding year were fifty-nine and twenty-one respectively.

While England and Ireland have such institutions under the Science and Art Department of the Committee of Council on Education, Scotland has none. But it has under that deputment of the Government exceptional facilities for the organisation of a School of Forestry on the lines I bave suggested. In the Museum of Science and Art, which is under their direction, there is, as has been intimated, a valuable collection of forest products, cnriched by a contribution of well-nigh 3000 articles obtained from the Forestry Exhibition, enriched al io with those placed at the disposal of the Committee appointed by the Conference held at the close of that Exhibition, anil according to crerlible 1eport, to be further enriched with the copious and valuable collection of the Scottish Arboricultural Society, making it probably the most comprehensive and extensive collection of such articles in Britain, if not in Europe or in the world; and in 
the same Museum are well-selected illustrations of entomology and other departments of zoology, of mineralogy and geology, \&c. And adjacent to the Museum is the Watt Institute, receiving grants from the Department, reported in 1885 , amounting to $f 179$, where it may be assumerl accommodation for classes might be obtained, and where, as in the University, contiguous to the Museum, accessory studies might be pursued.

By the nearest possible approximation to unanimity, the Committee appointed at a meeting held in the International Forestry Exhibition in Edinburgh to consider the means necessary to the establishment of a School of Forestry in that city, have advocated in preference to the organization of classes for the study of Forestry in Edinburgh by the Scierce and Art Department of the Committee of Council on Education, the establishment of a Professorship of Forestry in the University.*

Amongst other advantages of such an arrangement, the expense-subject to the disadvantage of not having a number of teachers of equal rank in mauy departments of forest science and of forest economy which it is expedient should be comprised in the curriculum of study, would be very much less; and this being determined there would be little probability of its being subsequently increased, unless the advantage of this should become manifest. There would be secured for the study, and for successful students, a prestige which might operate favourably both in securing students able to meet the expense of University instruction, and in securing the services of teachers of higher grade than wight be found willing to undertake the work in conuection with the more extensive arrangements which have been under

\footnotetext{
* The following are the names of the members of that Committee :-The Most Hon. The Mlarquis of Lothian, K.T., President; The Right Hon. Thomas Clark, Lord Provost of Edinburgh; Sir William IIUir, K.C.S 1., Principal of the University of Edimburgh : Alexander Dickson, Esq. of Hartree, II.D., Professor of Botany, Fdinburgh; Colonel IIurdoch Snith, R.E., Director of Edinburgh Jluseum of Science and Art ; Sir Alexander Christison, Bart., M.D. : Robert Hutchisol, Esq. of Carlowrie ; P. Neill Fraser, Faๆ. : J. Croumbie Brown, LL.D. ; Hugh Cleghorn, Esq. of Stlavithie, M.1). : Malonln Dunı, Fisq.; W. A. Relfrage, Esi., C.E. Colmel Dods, Conventr.
} 
consideration, and arrangements might be made for the students graduating in the University.

At a meeting of the Council of the Edinburgh University held in the month of July last (1886), on consideration of a communication from the Senatus as to the proposed rules for graduation in science in the Department of Agriculture, the draft of a resolution embodying the proposed rules was approved, and it was ordered that it should be submitted to the General Council of the University at their next meeting for their consideration, in terms of sec. xii. (2) of the Universities (Scotland) Act, 1858. It was also ordered that any communication which might be received on the subject from the directors of the Highland and Agricultural Society of Scotland should be transmitted to the General Council for consideration in connection with the proposed rules. The following is a copy of the proposed rules :-

'1. In the Department of Agriculture the degree of Bachelor of Science shall be the only degree conferred. 2. The rules as to a preliminary examination on subjects of general education shall be the same as those for graduation in the Department of Phvsical and Natural Science. 3. The rules as to attendance on qualifying classes for three sessions shall be the same as those for graduation in the Department of Physical and Natural Science; provided always that instead of one of such three years of attendance, a year may be spent on a farm or farms, in pursuance of the practical study of agriculture. 4. Each candidate must produce a eertificate of attendance upon a qualifying class on each subject of examination, if that subject is taught in the University; and if the subject be not taught in the University, lie must produce a certificate of attendance on lectures on that subject, at an institution recognised by the University for the purpose; and should he, instead of one of the three years of attendance required in section 3 , have spent a year in the practical study of agriculture, he must producc a certificate to that effect. 5. Therc shall be two 
examinations for the degree of Bachelor of Science in the Department of Agriculture. These examinations shall be writtell, oral, and practical. 6. The first examination shall be in-(1) Agriculture, to such extent as may from time to time be fixed by the Senatus; (2) Chemistry, to the extent required for the first examination for the corresponding degree in the Department of Physical and Natural Science ; (3) Engineering, with special reference to field work and draining; (4) Biology, (a) botany or (b) natural bistory -either subject at the option of each candidate. In either case the examination shall be to the extent required for the first examination for the corresponding degree in the Department of Physical and Natural Science. 7. Candidates who have passed the first examination may present themselves at the end of six months for the second examination. 8. The second examination shall be in-(1) Agriculture, the whole subject; (2) Chemistry, as applied to agriculture; (3) Geology, in so far as bearing on agricultural science; (4) Veterinary hygiene, to such an extent as may from time to time be fixed by the Senatus. 9 . Candidates who have passed the second exa:nination sliall be recommended to the Senatus for the degree of Bachelor of Science. 10. The examinations shall be conducted by University examiners appointed by the University Court, and an additional examiner in agriculture, to be appointed by the University Court, after communicating with the Council on Education of the Highland and Agricultural Society of Scotland, and considering any recommendation by them. 11. The fees for the degree of Bachelor of Science in the Department of Agriculture shall be-(1) For the preliminary examination, or for registration of any exempting qualification, $£ 11$ s; (2) for the first Bachelor of Science examination, $£ 22 \mathrm{~s}$; (3) for the second Bachelor of Science examination, $£ 22 s=£ .5$ ss.'

On consideration of a minute of Senatus, it was resolved to recognise the University College of South Wales and Monmouthshire as one of the institutions at which two of 
the three academic years of study of candidates for the degree of Bachelor of Science may be passed.

It seems reasonable to suppose that in the event of a Professorship of Forestry or of Forest Scieuce being established in the University, similar arrangements might be made for studeuts passing satisfactorily through this class, being also allowed to graduate in science.

In conjunction with such arrangements, or irrespective of them, arrangements might be made for the study of forestry being pursued in the Watt Institute.

The advantages of such an arrangement, amongst others, would be these:-It is a popular institution of compreliensive technological study, many of the classes of which might be made subservient to the study of forestry by students giving their attention to this ; and such a degree of completeness might be thus given to a prescribed programme of forestal studies that, without detriment to any other course of studies followed there in some of the sane classes, a fully equipped School of Forestry might be represented as one of the constituent parts of the institution. It would allow of expansion being easily given, temporarily or permanently, to the course of study in forestry, if this should at any time be deemed expedient, or of contraction or change in this, if such should appear advisable; and that without requiring radical or fundamental change, or such modification as would justify captious censorious remark.

The fees charged, if in accordance with the fees charged in the other classes, would be such as might be met without difficulty by students of limited means; while the hours of study, if like those of other classes, being in the evening, would suit the convenience of those who are engaged in daily labour; and others, who, from any cause, might prefer studying accessory subjects in the course of the day in the University, which is adjacent, would have the opportunity of doing so,-while the proximity of the Museum of Science and Art, with its invaluable collection 
of forest products, \&c., would give every facility for the study of these.

From what has been commuuicated to me, on what I consider good authority, students at the Watt Institute, whatever their skill and attainments might be, would not, according to existing arrangements, be eligible for admission iuto the forest service of India, which is at present the only very eligible career open to educated foresters; but I have no cionbt that students, trained as they might be in classes in the Watt Institute, would prove themselves the equals in every respect but that of social position, of those in that service who have studied in Nancy; that when this came to be seen, and recognised as a fact, their services would be in demand for even the Indian service; that whether they were admitted to the Indian service ur not, they would soon in India, or elsewhere, create their own prestige; and other students succeeding them, if such arrangements be carried out, would reap the benefit of this, and the School would rise in favour, On these points I have no misgiving or doubt.

Failing all of these plans whereby might be established a National School of Forestry in Edinburgh, or mean while until the necessity or the importance of something of the kind indicated being done, permanent or provisional arrangements might with advantage be made by existing organisations, or by private enterprise, to organise arrangements for the study of forestry there. The latter was what was contemplated by the Committee of which mention has been made as having been appointed at a meeting held in the International Forestry Exhibition, and it was only when they found that they could not obtain the requisite funds that they resolved to advocatc the cstablishment of a Professorship in the University.

As has been intimated, a large collection of implements, specimens of wood, seeds, fibres, \&c., was, at the close of the Exhibition, placed at the disposal of this Committee for use in connection with a proposed School of 
Forestry. In a circular which they issued under date of 28th January, 1885, the Committee intimated that they felt difficulty in suggesting a definite scheme for the organisation of the School until they had some knowledge of the amount of funds which might be placed at their disposal; but that they contemplated the establishment of a Professorship of Forest Science for the instruction of students in all that pertains to practical and to scientific forestry, including the physiology and pathology of trees, the climatic and other effects produced by forests, the different methods of forest management in use in this and other lands, the economic uses to which forest products have been, or may be applied, and forest engineering and forest administration generally : the instruction being communicated by lectures, examinations, written and oral, excursions, \&c. And should their funds permit, that the large collection of forest implements, produce, and specimens of various kinds illustrative of forest science and forest economy, with such additions as from time to time might be available, should be placed in a permanent museum in connection with the contemplated School of Forestry; for the accomplishment of all of which they considered $£ 10,000$ would be requisite.

In the end of 1885 it was found that a mercantile establishment, in which free storage had been generously given for the large collection of articles placed at their disposal, required the premises in which these were stored. In these circumstances the Committee deemed it expedient to make over the whole to the Museum of Science and Art, in which, along with others which have been procured, they may be permanently exhibited, so soon as the necessary accommodation for this can be provided; and the subscriptions placed at their disposal, amounting only to $\mathfrak{£} 660$, they resolved to advocate the establishment of a Professorship of Forestry in the University.

Should their original design be carried out by any, in so far as it related to study and instruction, whether this were done by private enterprise or by some one or other 
of existing organisations, such as the Royal Highland and Agricultural Society of Scotland, or the Scottish Arboricultural Society, this would give an opportunity of seeing, and of showing, what can be done with even limited means; and by inference, what might be done with greater or better means at command; and it would afford oppor. tunities for experimenting, and so preparing for the perfecting of a scheme, which, placed on a more satisfactory basis, might achieve all that is desired. It is possible that the insecurity in regard to continuance attaching to such arrangements, together with the absence of prestige, might have a prejudicial effect on the supply both of teachers and of studeuts; but even should it prove only a temporary arrangement, it might, in the absence of something more commanding in promise and in effect, do mucb good.

\section{Section 2.-Curriculum of Studi.}

I do not happen to know of a more eligible site for a British National School of Forestry than Edinburgh would be; and in proceeding to bring under consideration what I consider suitable curriculum of study for adoption, I assume hypothetically that others will feel with me that such is the case.

This assumed, it is requisite to the satisfactory projection of a programme of instruction to know something of the object to be kept in view; of the teachers to be employed - their number and their qualifications; and of the students who are to study there-their capabilities and the time they can give to their studies.

If the sole object aimed at be to impart the instruction necessary for the satisfactory management of woods and plantations in Britain, or for the satisfactory management of forests and plantations in India, or in one or another, or more-in any or all of our colonies, the curriculum might properly be determined by the circumstance of which 
one of these oljects was to be the object aimed at ; but as at comparatively little additional expenditure of teaching power and of money, there could be imparted the instruction which is required in common by all of these, together with much beside, which might be advantageous, in every way, this is what is desirable in a British National School of Forestry, and what alone would reuder any School worthy of such a name.

With this point settled, there arises the question of the number and qualification of the teachers to be employed, and the question, Where may qualified teachers of forestry and forest science be looked for with some hope of their being found?

There are three qualifications which I deemed desirable, if not requisite, in teachers in a School of Forestrythe necessary knowledge; power of communicating to others the knowledge which it is desired tbey should impart; and aptitude for teaching. It may be necessary in the commeucement of a School of Forestry to abandon the hope of securing in a teacher or teachers, otherwise eligible, one or more of these qualifications, whether it be determined to organise a school in a fully equipped condition, or one in what nay be called an embryotic form. Which should be sacrificed may depend on circumstances too varied to be specified.

Subject to this caveat I may mention that in the Plea for the orgaanisation of of a School of Forestry in connection with the Arboretum in Edinburgh, issued by me in 1877, I stated:-

'The laying out of such grounds can be executed only by a professional forester. But thereafter it may be open to question whether the curatorship of them should be entrusted to a practical or to a scientific officer, and if the latter should be resolved on, there is provision made for the experiment of introducing the study of forest science at little additional expense.

'I presume if this were done, and if it were extensively 
made known that this was the case : that there was an Arboretum, about 30 acres in extent, adjoining the Botanic Gardens and Experimental Gardens, in extent some 20 acres more, with a view described "as one of the most magnificent views of Edinburgh which could be obtained," and " as one of the finest in Europe, including as it did the northern portion of the city, with its spires and domes, and the outstanding eminences of the Castle, Calton Hill, Salisbury Crags, and Arthur's Seat," and that related studies could be carried on under such men as Sir Wyville Thomson, and Professors Balfour, Kelland, Tait, Jenkin, Wilson, Geikie, Hodgson, Stuart Tytler, and Alexander Crum Brown, with such assistants as they have, and such men as are gathered around Dr Stevenson Macadam and Mr Lees in the Watt Institution, there will be no lack of candidates for the work.

'I consider that there must be many of the officers of the Forest Service in India well fitted, by previous training and experience, for conducting such a course of study as I have proposed Failing this, there might be found, by correspondence with students of forestry on the Continent, able men who might be willing to master the English language and give lectures on some or all of the subjects I have enumerated.

'I have, for some years, myself been engaged in the compilation of information on subjests connected with Economic Botany, with a view to this being, if not previuusly printed, or otherwise used, deposited in manuscript in the Public Library, Cape Town, Cape of Good Hope, for consultation by scientific and practical men seeking to develope the vegetable resources and the agricultural capabilities of that colony; and I have ready, compiled and translated, all the material requisite for such coirses of lectures on Forest Science as I have spokeu of. If other duties permitted, I should esteem it an honour, as any man might do, to be entrusted with an opportunity of testing the practicability of establishing a British School of Furestry in connection with the proposed Arboretum; 
and from this I conciude, that no difficulty need be anticipated in procuring teachers, if only the necessary arrangements for the teaching were made.'

This speaks of the past, not of the present; but as I felt then, many, I doubt not, will feel now, or as soon as measures may be matured for the opening of the School. I anticipate a plethora, and not a lack of candidates.

In order to the projection of a satisfactory programme of study, it is necessary to know something of the attainments and other qualifications of the teacher or teachers whose services can be obtained.

But beyond this there are to be taken into account the number and capabilities of the students, the period over which the curriculum is to extend, and the number of hours which the students can daily spend in class studies.

In lack of all these data it is impossible to speak with the precision which might otherwise have been practicable: they are important, but they are as yet unknown qualities.

With these unknown, I may state that in the Plea for the establishment of a School of Forestry in connection with the Arboretum in Edinburgh, which I issued in 1877, I submitted the following, as what I deemed at that time practicable and suitable; mentioning that I still deem them so.

'Since my return tu Europe, some ten years ago, from the Cape of Good Hope, where I held the appointments of Colonial Botanist and Professor of Botany in the South African College, I have, with the exception of a brief period, beer in constant communication, personal and epistolary, with professors and students of forest science, and officials entrusted with the management or administration of forests in Britain, on the Continent of Europe, in the United States of America, in the British Colonies, and in India, having in the course of that time visited the United States a second time, and travelled extensively in France, Bavaria, Austria, Russia, Finland, Prussia, and 
Belgium, to obtain and to verify information otherwise obtained in regard to forest, economy and forest science. And I submit for your consideration the opinion that, with the acquisition of this Arboretum, and with the existing arrangemeuts for study in the University of Edinburgh, and in the Watt Institution and School of Arts, there are required only facilities for the study of what is known on the Continent as Forest Science to enable these Institutions conjointly, or either of them with the help of the other, to take a place amongst the most completely equipped Schools of Forestry in Europe, and to undertake the training of foresters for the discharge of such duties as are now required of them in India, in our Colonies, and at home.

'I have before me the Programme de l'enseignement i L'Ecole Forestiere, at Nancy, and the official Report of the prescribed studies in the Central-forstlehr-Austalt, at Aschaffenburg, and I am more or less acquainted generally with the courses of study followed at most of the other Schools of Forestry in Europe; and I consider that some such course of study as the following would be equivalent for the purposes of our countrymen to that followed in any one of these valuable institutions, with the advantage of not requiring the acquisition of a foreign language, which few of our foresters and sons of foresters have facilities for effecting, or at least of effecting to such an extent as to enable them to understand instructions as thoroughly as they would instructions given in their own tongue:-

\section{' FIRST YRAR.}

\section{'Winter Session-}

'Instruction to be given in the structure and physiology of Trees and Shrubs; in the gengraphical distribution of Forests; in the treatment of Forests by Sartage, by Jardinage, by à tire et aire, and by les Compartements, or the Fachwerke Methode of Germany ; in the application of this to coppice wood, with a view to securing, 
along with other advantages, a sustained production of wood; and in the application of it to timber forests, according as the object may be to secure from these a maximum size of timber, or a maximum proluce of wood, or a maximum pecuniary return, along with natural reproduction, sustained production, and progressive improvement of the woods: and in measures to be employed in the conversion of coppice wood into timber forests, of timber forests into coppice wood, of mixed woods into either, and of either into mixed woods ;

'With attendance on the classes in the University for the study of Natural History, of Mathematics, of Engineering; or with attendance on the classes in the Watt Institution and School of Arts for the study of Mechanical Philosophy, and of Mathematics.

' Summer Session--

'Attendance on the classes in the University for the study of Botany and Vegetable Histology; and of Practical Natural History; and of Practical Engineering; or attendance on classes, if open, in the Watt Institution for the study of Botany, and of Mechanical and Geometrical Drawing.

\section{Autunn Months-}

' Tours of observation, with or without the teacher, in woods and forests in Britain; in France, in Germany, or in the North of Europe.

\section{'SECOND YEAR.}

Winter MonThs-

'Instruction in regard to Forest Economy, Forest Legislation, and Forest Literature in Britain; in Frauce and in Germany, countries in advance of all others in Forest Science, and in the practical application of it to the management of forests; in Russia, where arrangements are being made to introdnce and to carry ont extensively the improved forest manage- 
ment practised in Germany and in France; in Finland, where arrangements have been made to manage the forests in accordance with the requirements of Forest Science; in Sweden, where the latest arrangements suggested by Forest Science are heing carried out with vigour; in British Colonies; in the United States, and in India where have been introduced many of the suggestions of modern Forest Science, and the Forest Economy practised on the Continent of Europe ;

'With attendance at the classes in the University for the study of Theoretical Chemistry and Practical Chemistry, and Natural Philosophy, and the practical application of the same; or with attendance at the classes in the Watt Institution and School of Arts for the study of Chemistry, of Engineering, and of Geology.

'Summer and Autumn Monthi-

'Practical experience in the management of Woods, or in the management of Nurseries, to be acquired under the direction of approved foresters or approved nurserymen.

\section{'THIRD YEAR.}

'Winter Session ONLY-

'Instruction in the Chemistry of Vegetation and of Soils; in the Meteorological Effects of Forests on Moisture, on Temperature, and on Constituents of the Atmosphere; in Sylviculture, as applied in Belgium, \&c., to utilise waste lands, - in the Landes of France, to arrest and utilise drift sands, - in the Alps, the Cévennes, and the Pyrenees, to prevent the disastrons effects and consequences of torrents, - on the Karst, in Illyra, to restore fertility to a lani rendered sterile by the destruction of trees, - in the United States of America, to prevent anticipated evils,-in India, to secure desiderated good,-in 
Britain, to increase amenity, covert, and shelter ; and instruction in the injurions effects of animals, birds, insects, and various diseases on trees;

'With attendance on the classes in the University for the study of Geology, of Agriculture, and, if it be lesired, any of the following: for the study of Political Economy, of Conveyancing, or of Bandaging and Surgical Appliances; or with attendance on the classes in the Watt Institution for the study of Animal Physiology, of German, or of French.

'In the curriculum which I have sketched, I have had regard to all that is required in Continental Forest Schools, and only to what is required in some, if not in all, of these institutions, in the study of what is included under the designation of Furest Science. I have also had regard only to the teaching power of the University of Edinburgh, and of the Watt Institution and School of Arts, as existing provision for the teaching of the classes specified.

'In many of the institutions referred to, the provision for practical training in woods and forests is much more ample than is at present at command in Britain; but there is here a curresponding reduction in the time allotted to the curriculum ; and tilis is so arranged that it may be entered upon at the cominencemest of any one of the sessions.

'It is contemplated that the studies should be conducted by the use of text-bouks, by lectures, by oral examinations at which the students should be encouraged to ask questions of the teacher, by written exercises of varions kinds, and hy formal discussions by the students under the presidency of the teacher.

'And it is contemplated that the class should meet for' an hour five days a week, at a time which would not interfere with the classes attended at the University, or in the Watt Institution.'

In the enumeration of classes in the University and 
in the Watt Institution which might be attended by students of Forestry, I gave the names of the professors, lecturers, and teachers then in charge of those classes. Many of the honoured men whose names were then cited, are no longer amongst $\mathrm{us}$, but others have entered upon their labours, men to be assoeiated with whom many would esteem to be an honour and a privilege.

For thoroughly efficient and satisfactory teaching in the subjects of special study mentioned, there would he required a staff of at least three teachers, one giving instruction in forest science; a second, in forest economy and sylviculture; and the third, in arboriculture and the manigument of woods and plantations such as are seen in Britain. But neither is it necessary to have so many teachers from the first; nor is it necessary to have only these, or no others until these may have been installed.

A commencement might be made with one te:cher, and I had almost said, with a teacher in any one of these departments of study. Supposing a commencement made with a teacher of forest science; a teacher qualified for conducting the studies of a class satisfactorily in forest science would be one qualified for communicating instruction in both of the other departments; and with such instruction in these as might be given by him, the promoters and supporters of the school might rest satisfie I till the necessity for an aldition being male to the reaching power of the institution began to manifest itself. Then, another being added, the first would be relieved of having to give instruction in the department issigned to the new teacher, whether this should be one or other of those mentioned, or some one or more of departments of sturly comprised under the comprehensive designation Forest Science; and thereafter successive differentiations conld be introdnced as circumstances might require or warrant.

It may be questionable whether this could be done with a Professorship of Forestry in the University: 
but so far as appears, it might be done if arrangements were made for the study of forestry in connection with the Watt Institute, the Highland aud Agricultural Society of Scotland, or in connection with the Husenm of Science and Art in Edinburyh, on terms similar to those of the Royal School of Mines and Practical Geology in London, and the Royal College of Science in Dublin, all of which admit of expansion and curtailment, and changes being made more easily than could de done with a professorship in the University,

\section{Section 3.-Expense.}

The expenditure which might be entailed, by arrangements such as had been under consideration, should not, even with the expenditure already incurred on the annual maintenance of the Museum, make the total expenditure of the Department in Echuburgh equal to the expenditure on the Normal School of Science, and Royal School of Mines, in London; or approximate by thousands of pounds the expenditure on the Royal College of Science, and the Museum of Science and Art, in Dublin. Nor would it involve an expenditure on a National School of Forestry out of keeping with what is spent on such institutions elsewhere.

There is some difficulty in stating what may be considered the total expense incurred in the maintenance of almost any of the Schuols of Forestry on the Continent: from this circumstance among others-in the published accounts no mention is made of what might be considered the equivalent of rent for the premises in which the school is located, and of the grounds connected with thesewhether a simple arboretum, or an extensive forest as the case may be. I know not an exception. The premises and grounds, sometimes a mansion, sometimes a palace, with corresponding appointments, is granted by the Government free of reckoning. The reut of such premises, 
if charged, would add greatly to the actual expenditure. But so would it be here.

On examination I find in the Forest Budget of Spain for 1882, and I have no reason to suppose that that was in any way an exceptional year, the credit asked and granterl for the School of Forestry was 33,750 pesetas or francs; but this did not include the salaries drawn by the director, professors, and assistant professors, as members of advanced grades in the Corps of Forest Engineers, amounting to a much greater sum, probably abont 70,000 pesetas: in all, 103,750 pesetas, say $£ 4,600$.

In the French Forest Budget for 1880, and in that of the preceding year, 1879, there was asked and granted for instruction in forestry $208,78.5$ francs, about $£ 8,700$, of which sum 98,800 francs were designed for the School of Forestry at Nancy; and it is this alone perhaps with which we need concern ourselves here.

There existed at that time an organisation for imparting what is called secondary instruction in forestry in other schools situated at Villers-Cotterets, Grenoble, and Toulouse, to which forest engineers under forty years of age were admitted withont being subjected to an entrance examination. 'The course of instruction extended over seven months; this was attended by men in active service, and any who passed satisfactorily the final or exit examination were eligible for appointment as Garde-general adjoint. But it was found by a subcommittee of the Chambre, to which had been submitted questions relative to the instruction in forestry, thit the system followed at these schools failed generally to produce men fitted for the duties which the holders of that office were, by the forest regulations, required to discharge; and the committee recommended that these schools should be given up as not accomplishing the object for which they were organised. The instruction given in these schools represented an annual expense of 22,300 francs.

The credit granted also included provision for the Ecole Forestiere at Des Barres-Loiret, founded by M. Vilmoriu, 
and so designated by him in contradistinction on the onc hand to a nursery, a designation borrowed from domestic life; and in c ntradistinction on the other hand to a plantation or forest, it being a collection of trees raised from seed obtained from forests or from nurserymen or seedsmen of note, and reared with a view to the study of their habits, their identity, and their differences: an cstablishment such as an arboretum might be made. Subsequently to the death of the founder it became State property. Since then it las been greatly extended, and there are received into it, after passing satisfactorily an entrance examination, sons of forest overseers, for two years' study, to prepare them for employment as gardeners or as forest warders; instruction being given to them in French, drawing, mathematics, land surveying, sylviculture, and all details of forest service. For this instruction there was allotted 20,610 francs, to cover the salaries of a director, of a garde-general or warder, and of a brigadier, the wages of the students, and other expenses for materials. The grant for the whole of the Schools was, as has been stated, 208,78. francs-say $\mathfrak{L} 9,280$.

I cannot conceive of any circumstances in which the expenditure on a National School of Forestry in Edinburgh, if regulated by reasonable economy, should approximate that incurred on the maintenance of the School of Forestry in Nancy, or the School of Forestry in the Escurial, unless itexpanded far beyond the arrangements found sufficient in these institutions; nor is it necessary that the expenditure at first should exceed what might be required to make efficient the teaching of one instructor, or afterwards be increased unless the first lectureship or professorship should produce results such as would make it manifest that it would be pecuniarily advantageous to the empire to perpetuate and extend the arrangements made. And these amounts are much short of the expenditure insured on the existing Royal School of Mines in Lon lou, and the Royal College of Science in Dublin. 
On the Normal School of Science and Royal Sclivol of Nines in London there were expended in the financial year terminating on 31st March, 1885, £14,313, 2s 5d; ou the Royal College of Science, Dublin, $\mathfrak{E}(j 804,1 \mathrm{~s} 4 \mathrm{~d}$; with $£ 14,056$, 15s $10 \mathrm{~d}$ for the Dublin Museum of Science and Art. The expenditure on the Edinburgh Museum of Ścience and Art was $£ 10,689,2 \mathrm{~s} 11 \mathrm{~d}$, and such an arrangrement as I have submitted for consideration would at first, or even when fully developed, require no such expenditure as these. And the expenditure would be entailed latgely by provision for the support of students prosecuting their studies.

The arrangements for the support of students is similar, if not identical, in London and in Dublin. I may then take for illustration the Royal School of Science in Dublin. This supplies as far as practicable a complete course of instruction in science applicable to the iudustrial arts, especially those which may be classed broadly under the heads of mining, engineering, and manufactures, and it is intended alsu to aid in the instruction of teachers for the local Schools of Science. Students may enter as associates or as non-associates. By 'assuciate students' is meant all those whu enter for the three years' ' curriculum of the college ' in any department. 'There are nine ' royal exhibitions' of the value of $£ 50$ per annum, entitling the holder to free admission to all the lectures and to the laboratories; these are tenable for three years. And there are four 'royal scholarships' of the value of $\mathfrak{E 5 0}$ yearly each. And there are thirty-six 'national scholarships.' These are of the value of $30 \mathrm{~s}$ a week during the session of about nine months for three years, and they are tenable at the option of the holders at either the Royal College of Science, Dublin, or the Royal School of Mines, London. They also entitle the holders to free admission to all the lectures and all the laboratories.

Of the Royal Exhibitions, there are three open for competition annually. Of the Royal Scholarships, two 
are offered for competition each year to students, not beiug royal exhibitioners, on the completion of their first academic year. Of the National Scholarsbips, twelve are open for competition annually to persons who have taken a first or second certificate in the advanced stage in any subject of science in the examinations of the Science and Art Department, and who show that they are bona-fide science teachers. Holders of these may attend all the day lectures gratuitously, provide l that they be examined on in at least one subject, and that they pay a fee of $£ 1$ for each course in which they propose to be examined.

The fees chargred to associate students for lectures and laboratories average $£ 15$ a year. Students wishiug to make une payment for the whole three years' course of lectures are allowed to compound for $£ 2.5$ in addition to the laboratory fees. The fees payable by non-associate students are $\mathfrak{E} 2$ for each separate course of lectures, with charges for laboratory instruction, graduated in each class according to the time attended. A non-associate student taking a complete course of instruction is admitted at the same fees as are charged to associate students; and in any case such receive certificates after examination, if they have attended two-thirds of an entire course of lectures. By these arrangements provision is made for cuabling students of limited means to meet the expense of buard and education without loss of self-respect. They are similar to those earried out in London; and if such were made in connection with a School of Forestry in Ediuburgh they would bring the course of study prescribed, in whole or in part as the student might wish, within reach of a great number of intelligent young men, who could not meet the expense of University life and University fees, with the advantage supsradded that the holder of the exhibition or sebolarship would have the satisfaction of knowing, and of having it known by his fellow-students, that this he has secured by giving evidence of his qualification for engaging in the studies to which he aspires,--which may be more than they could 
have donc. And at the same time, a certificate of his having obtained such exhibition or scholarship, with certificate of his having passed satisfactorily both the entrance and the exit examinations of such a Governnent institution, might have assigued to it a definite value in auy application the holder night make for a Government appointment at home or abroad.

If similar provision were made for students of forestry, should a School be organised in connection with the Science and Art Department of the Committee of Council on Education, this would only be in keeping with what has hitherto becn done for aspirants for employment in the Forest Service of India.

In an editorial note in the number of the Journal of Forestry issued in March, 1879, it is stated :-

'We regret to find that no attempt has yet been made to reduce the enormous expense to which the country, and the parents or guardians of a pupil, are put to pay for his training in the Forest School at Nancy, an institution, too, be it observed, that does not at all meet the requirements necessary for the proper training of first-class forest officers for the management of the forests in British India or in the Colonies. Each pupil costs, for fees and maintenance, $£ 220$ per annum, of which heavy sum the pareuts are held liable to pay $£ 180$, which may be reduced to an average of $£ 120$ per annum by the industry and good conduct of the pupil; in reward for which the Government, at its discretion, pays the difference, $£ 60$ per annum.

'Such heavy charges can only be afforded by the opulent classes, and very much exceed the cost of training for any other profession in this country. They are also quite prohibitory to the young men best qualified by nature and early training for filling the office of forest officers in India or elsewhere. For less than half that cost per head per annum we train our clergy, doctors, lawyers, naval and military officers, engineers, \&c.; in fact, we do not know of any professional training which necessarily requires such 
an enormous expenditure for such poor results. Suppose there is an annual average of fifteen pupils being trained at Nancy for the Indian forest service. This would give a total cost of $£ 3000$ per anuum. Such a large sum properly expended in training forest students in a Forest Department in connection with any of our Universities would train fifty students in placc of fifteen, and make inuch superior men of them for the duties they are called on to perform in the management of our home, colonial, and Indian forests. The special training for India, or any colony, should be taught in that country. The science and technics of forestry can be better and more economically taught in Britain than anywhere else, and the practical training specially necessary for any particular country cannot be so well taught anywhere as on the spot where it has to be put into practice.'

Mr W. G. Pedder, revenue secretary, India Office, in giving evidence before a Select Committee of the Housc of Commons in July 1885, it is reported in a subsequent issue of that periodical, September 1885, stated, in regard to candidates for employment in the Forest Department in India:- 'It was found that the young mon sent to France were not sufficiently well acquainted with the French language to acquire knowledge through that medium. A change has consequently been made. The young officers selected were sent to undergo a course at the Royal Engineering College at West Hill, where they were instructed in the ordiuary engineering education, and in addition were taught Forestry, and Botany, and Forest Law, and Jurisprudence.

No application had been received from other than the Indian Department; but no doubt other students would be received, who would pay the fees of $£ 180$ a year, including everything excepting pocket-money.'

At much less expense than this, then, might be provided in Edinburgh, education, instruction, and training, equal to what has hitherto been given to candidates for appoint- 
ments as forest officials in India; and such, it may be assumed, would suffice for candidates for similar appoiutments in our colonies and at home.

In an editorial note in the Journal of Forestry for March, 1886, it is stated :-

' The fees for the course of training at the Forestry School at Cooper's Hill are, according to the evidence given by Mr Pedder before the Select Committee on Forestry, fixed at $\mathfrak{£ 1 8 0}$ a year for each student. This sum covers all expenses except pocket money, viz., board and lodgings, lectures, and a six weeks' tour annually to the Forest School at Nancy. The sum is large, so large indeed as to be probibitory to all poor aspirants for distinction in forestry science; we do not, however, say nor imply that the amount is too large to cover the expenses of the scheme on which the school is founded. This is a point we do not at present intend to touch upon. What strikes us as most objectionable in connection with these high fees is the fact that they will narrow the field whence forestry students may be drawn, in such a way as to exclude the whole of those who may be reasonably expected to be specially fitted by the circumstances and associations of their early years to enter on the study with a bent in its favour that would assure the highest success. We allude to the sons of practical foresters, and to young foresters generally. It inay fairly be presumed that young men who liave been associated with trees and with woodland management for many of the earlier years of their life, have acquired a large amount of information of a practical kiud respecting these subjects, and also a love of trees, which not one in a thousand candidates from any other field can possibly possess. Yet this valuable element is to be excluded from the public service because they are unable to pay the fees which are required to cover the expenses of the scheme of training decided upon. Surely this is matter for deep regret from all points of view. The annual fee is in point of fact three or four times the amount of the yearly salary of the average English forester. It is thereforc obvious 
that he caunot place his son at Cooper's Hill Furcstry School, let his capacity and bent for such a career be cver so conspicuuusly marked. This we consider is a serious mistake, alike in national and individual interests, at which should be speedily rectified by some means, either at Cooper's Hill, or by the establishment of a less costly school elsewhere. The six weeks' annual sojourn of the students in France must add very materially to the costs of the establishment at Cooper's Hill, and, it may be asked, for what good? It is difficult for any one outside the pale of officialism to conceive what practical advantage will accrue to the Indian Forest Service (in whose interests this annual continental visit of students is planned) from a mere holiday of a few youths to the forests in connection with the school at Nancy, during which in the circumstances they can see and learn little that they may not see and learn in India, where a similar system of forest management is in practice. Obviously it must be a matter of very little consequence whether these youths reach India with or without twelve weeks of such experience, if they have undergone the course of scientific and technical training prescribed in all other respects satisfactorily. It would be incredible to suppose that such a meagre insight into the practical features of sylviculture as may be obtained in the circumstances would be considered sufficient qualification in the estimation of the authorities to place these young men in posts of responsibility - as, for instance, to direct or control labour in the forest without superior control-immediately on their arrival in India. Although we are told by the same witness in the same report that only the inferior grades of forest officers are trained in India, it is too absurd to imagine that there is no course of training for the young men who have passed at Cooper's Hill as qualified at from 19 to 24 years of age after their arrival in India. If then, as we are bound to assume is the case, these students arrive in India incapable of undertaking even subordinate responsibility in practical forest work, after they have finished their course of study 
at Cooper's Hill, would the omission of their annual visit to Nancy of six weeks for two successive years be a regrettable matter in auy way? We think not, but leave practical people to draw their own conclusions.' 


\section{CHAPTER III.}

RELATIVE IMPORTANCE TO A SCHOOL OF FORESTRY, OF SCHOLASTIC SURROUNDINGS, AND OF ADJACENT FORESTS.

Is discussing in a preceding chapter the question of an appropriate site for a British National School of Forestry, I have adverted [ante p. 174] to the practicability of securing by feu, property in the immediate vicinity of Edinburgh, on which might be created a forest, in the creation and subsequent management of which students might hereafter be exercised in all that pertains to practical forestry, if Edinburgh should be selected as the site of such a School of Forestry.

This matter demands further consideration in connection with the subject of the immerliately preceding chapter - that of expense. Is such a forest really necessary to the efficient teaching of forestry and forest science? Many will say yes; beyond all doubt or question it is. That advantage might be derived from the creation of such a forest may be freely admitted; and that thus the efficiency of the teaching might be increased need not be denied, but the expense would be considerable, and I do not consider it necessary that that expense should be incurred. It may be asked, Is it not necessary to the efficiency of a Scliool of Forestry to have adjacent to it a forest, in which the students may be exercised in various departments of forest work? There prevails in Britain an opinion that it is. But I consider this a prejulice, by which I mean an opinion formed a priori, and not the result of observation; and nue which has retarded the establishment of a School of Forestry in Britain, by suggestions of an enormous expenditure for which it would be difficult to provide. 
Dr James Brown, in his treatise on Forestry,* already referred to, laments that there is nota school in Great Britain where young men can learn efficiently all the branches of study in connection with forestry ; and he gives the following advice as to the way in which a self-supporting institution for that purpose might be established: "Let an arboricnltural association be formed of some of the leading landed proprietors in the country, with a few men of science among them, having for their object the cultivation of trees on the most approved and improved principles of the age, and the training up of young men as foresters according to these principles, in order to fill the places of the existing foresters of the school, and thus as early as possible bring about an improved state of arboriculture for the general welfare of the country.

'Then, supposing that such an association were furmed, where and how is the field of their operations to be had? Of course, they could not undertake anything in a definite and practical way in respect to fore-try withont this. Such a field may be easily had, as there are many landed proprietors in this country who have more estates than one, and who would he willing, I have no doubt, to give over the woodlands on one of them for the purpose of forming an arboricultural school of it, of course under safe and proper conditions to both parties. The outline of the conditions might be made somewhat as follows: The proprietor, R. F., lets to the association —-, for a period of, say forty years from date, all the woodlands at present on the estate of A., extending to about 2000 acres, as per plan of the property to be referred to, at an annual rent of $£$ - The several crops embraced to be thinned, and otherwise to be dealt with for their improvement in health and value by the said association, and according to a mode to be proposed by them and approved of by the said R. F., the proprietor, who is to sell the timber and

'Forestry; or, A practical treatise on the planting, rearing, aml general management of forest trees." fourth ellitiun. Willian lilackwood \& Sols, Fidinhurgh anl London. 15,1. 
other produce for his own behoof, the association to be paid by him for the labour performed by them in dealing with the works of thinning and otherwise improving the crops, as may be agreed upon, all at the usual rates for such works; these to be agreed on between the association and the said proprietor's agent at the beginning of each year, and before the works commence for the season. And the said R. F., the proprietor, lets also to the said association, for the said period of forty years, for the purpose of being planted by them from time to time with suitable kinds of trees, as may be agreed on between the parties, that piece of waste land known as - and extending to 1800 acres, at the annual rent of $£-$. This portion of land is let to the association on the understanding that, at the end of their lease, the said R. F., the proprietor, shall take over all the crops that shall then be found growing on it, at a valuation to be settled by two neutral men of skill, mutually chosen, when the said R. F., or his heirs, will pay the association the full value that may then be made in respect to the crops of trees that may have been planted by them on said land. And it is to be understood that during the currency of the lease the said association shall have full power to manage the woods they may plant on said waste land in their own way aud as they may think fit, and to use for their own behoof all proceeds arising from them; it being understood, however, that all the crops they may plant shall be properly treated and trained, so as to insure their being valuable to the estate as a crop on the land, when they are handed over to the proprietor of the land at the end of the lease. And it is also agreed that the said association shall have no power to clear any portion of said crops or trees they may plant, or any portion of any crops, whatever, without the consent of the proprietor of the land.

'A president and vice-presidents, with directors, woulıl have to be appointed, as also a secretary, a treasurer, and inditor. Next, the working-resident staff might be a manager, who wonld be accountible to the president and 
directurs for the proper working of the objects of the association. He would be assisted by a professor of botany and vegetable physiology, and one of geology and chemistry, the latter combining physical geography and climatic science; while he, the inanager, ivould also have the assistance of a first-class practical forester, whose duties would be to carry out all the practical operations, under the directions of the manager, in dealing with the woods, and at the same time instruct and guide the pupils while at their various works in the woods.

'To accommodate a staff of this kind, together with, say fifty or sixty pupils, a convenient house would require to be provided, and as to whether the pupils would be resident in it or not, would of course depend on a careful consideration of all the circumstances in connection with the locality in which the field was situated. At all events, one-hialf of the pupils would require to attend at a given hour every morning, to hear lectures and other instruetions on the subjects to be taught by the professors, while the other half would go out to work in the woods. These would return in the afternoon to get their course of instructions, while those who were studying in the morning would go out and take their places in the woods; and in this way the routine of daily theoretical and practical instructions would be carried on. Of course a portion of the waste land would be taken up for planting every year, in order to have the young men trained to the proper way of doing it, as also thinning in the different plantations, with bark-stripping, pruning where necessary, draining, \&c. In short, all these branches of work would be undertaken every year on some portion of the crops; and as all the works would be performed by the pupils themselves, under the direction of the forester, every one would have the full opportunity of gaining practical experience, as well as theoretical knowledge, on the various branches of forestry. And it would be necessary to keep all the wnorls under the management of the association in the very best possible condition, so that 
their character might become a model for all others to imitate. And, bssides, it would be desirable for the manager and his professors to visit, from time to time, the woods on other properties, and take with them their pupils to see them, when they would have an opportunity of comparing the managenient of other woods with that of those on their home district; and in this way the pupils would get much useful information and experience, within the shortest possible time, under the guidance of their teachers, and thus render them more intelligent and experienced than they would be were their observations confined to the woods on the home field alone.

'In dealing with the pupils, the amount of fees they would pay would, of course, depend upon whether they were lodged in the institution or not, and had bed and board provided for them. I should say that they should be resident in the institution, and all receive like treatment as to education, board, and lodging. If they were not resident lodgers, irregularity would be certain to ensuc, and want of pruper rule. Then, if lodged, $£ 50$ a year might be a fair charge for each pupil. At all events, it should not exceed this sum. In accounting with the pupils they ought to have put to their credit, and deducted from their fees at the end of each term, when settlement is maie, the value of the work they perform in the woods, at a fixed rate per hour or per day, as may bo arranged. This would make them more industrious than they otherwise would be, and make them take good interest in the works they were engarged in. This value of work would, of course, be refunded to the association by their account against the proprietor of the woods for the work performed in them by their pupils.

' In order that the pupils might be properly iustructed in all the branches bearing on arboriculture, and to secure the professors an 1 all concerned doing their duties, an examination of the progress made by the pupils should be made by the president. and directors at the end of every six months, and afterwards put to the credit of the most proficient and de.erving. 
'As the young men became proficient in all the branches (after three years' residence at the institution), theoretical and practical, of forestry, and leave the institution, they should have each his certificate or diploma, stating his general acquirements and abilities, and whether he is first, second, or third class in his profession. These certificates should of course be given by the president and directors, and signed also by the professors; and they should form a guarantee to landed proprietors who might be in want of foresters that the holders are men of undoubted professional abilities, and worthy of being trusted with the mangement of their woods.'

In the first editorial article in the Journal of Forestry it is said, vol. i., p. 9: ' It is necessary for a properly equipped Forest School to have a large extent of forest attached to it, having a variety of elevations and soils suitable for the, profitable cultivation of all our hardy trees, besides the garden, nursery, or arboretum, which forms the nucleus or head-quarters for the schools. By proper arrangements, such an extent of suitable land could be got within easy reach of Edinburgh, along the slopes amongst the glens, and upon the Pentland Hills; or if for a school in England, amid the uplands of Surrey and Hants, or among the hills of Derbyshire, or in Wales, where trees thrive to perfection, and the land is of comparatively small value for any other purpose.'

At a meeting of the English Arboricultural Society held last summer - 1886, there was anvocated by $\mathrm{Mr}$ Wallace, land agent for Ravensworth, the purchase, with Government assistance, of a large tract in the Northumbrian Hills for a Forest School on a large scale. It was with the design that this should be in addition to anything which might be done in Scotland, it being allegerl that it was well known that trees growing luxuriantly in Scotland will not live in the north of England. 
In the evidence given before the Select Committee of the House of Commons by others, the same idea was advanced. I have intimated that I think otherwise.

The earlier German Schools of Forestry were instituted in connection with forestal operations, and consequently in connection with extensive forests; and the earlier Schools of Forestry instituted in accordance with them as a model were naturally established in connection with some extensive forest. But after a more extended experience had been gained, and greater facilities for travelling great distances at comparatively little expeuse were created, the Schools of Forestry were removed from the forests to seats of learning in the cities and towns, and combined with Universities and:Polytechnicums, and Schools of Agriculture and Rural Economy, and only in connection with like educational institutions do I know of Schocls of Forestry having been of late years organised.

It appeared to ine in visiting Schools of Forestry and in reading of their origin and cxistence, that most, if wot all, of the old-establisheil institutions were adjacent to forests. while most, if not all, of the later fonniled schools were not; and that some of these made much more use of forests somewhat remote from them for the practical training of students than did some of the former appear to me to make of like facilities for the work at their own door.

I have met with convictions in farour of different forms of ecclesiastically prevailing on this side, and on that of geographical boundaries; and so have I seen it with these conflicting opinions in regard to such forests. In the older Schools of Forestry in Germany, which are in the northern part of the Empire, we have the former; in the later formed schools in the sonth we have the later.

And certainly it was the case that practical training was not neglected by any-I never heard a complaint made of want of facility for securing this; and my opinion is decidedly in favour of the erlucation and technical instruction being 
prosecuted in connection with facilities for prosecuting without interruption these and higher studies, with some time spent annually in observing, and, if possible, in practising forestal operations under properly qualified teachers of practical forestry. And I have stated in the preceling chapter, on an appropriate site for a British National School of Forestry [ante. pp. 174-7], how this might be done if Edinburgh were made choice of for the site of such a school.

Having made this statement, I feel free to advance, and state that I have never known of a forest official in the south of Germany advocate a return to the old model in so far as this was essentially a school organised in connection with a forest, and I have never known such a location fur a School of Forestry advocated in Germany or out of Germany by any one known to ine to be acyuainted with the details of instruction in different existing School; of Forestry, who had not himself been educated at a Schonl of Forestry so located. I do not call in question the fact that such may have had far better opportunities of forming a satisfactory opinion on the subject from experience than I have from limited personal observation and hearsay; and I have mentioned the fact cited in the full knowledge that it may tell both ways.

In more than one case on visiting a School of Forestry, I have looked in vain for a forest, or even for an Arboretum, such as that in Edinburgh is becoming, and yet may become; and even where a removal of location has been made to the site now occupied by a school adjacent to a forest, it has never been from a University town to an exclusively forest district, but the reverse, with perhaps an exception which will be mentioned.

In Denmark, the School of Forestry is conectedn with the School of Agriculture and Rural Economy in Copenhagen. In Sweden, the principal School of Forestry is in Stockholm, and the practical training is effected at a distance. In Finland, the School of Forestry is at Evois, 
adjacent to a forest; but the practical training is conducter elsewhere. In Russia, the principal Schools of Forestry are in St. Petersburg and Moscow ; the practical traiuing is at Lissino. In Saxony, the School of Forestry is at Tharand, adjacent to a forest. In Prussia, the School of Forestry is at Nenstadt Eberwalde, adjacent to a forest. In Hanover, it is at Munden. In Hesse-Darmstadt, the School of Forestry, after mature deliberation, was incorporated with the University of Giessen. In Baden, the School of Forestry is connected with the Polytechnicum of Carlsruhe. In Wurtemburg, it was part of the Royal Academy of Rural and Forest Economy at Hohenheim; but I understand it is now combined with the University of Tübingen. In Bavaria, the School of Forestry acquired a high reputation at Aschaffenburg, whence it was removed to be combined with the University of Munich; subsequently Aschaffenburg was re-occupied as a preparatory School of Forestry, from which students proceed to Munich : but my latest information from Bavaria does not speak in commendation of the measure. Be this as it may, it is the only case of the kind known to me. The buildings were vacant; the inhabitants of the adjacent town were urgent; but even if the most were made of it, it could scarcely be considered an exception to what I have stated. In Austria, the School of Forestry has been removed from Mariabrum to Vienna. In Italy, the School of Forestry is at Vallambrosa, in the midst of a forest; and in Gotha, the School of Forestry is in Eisenach, not far from a forest. In Switzerland, the School of Forestry is combined with the Polytechnicum at Zurich. In France, the School of Forestry is in Nancy, adjacent to a forest. In Spain, the School of Forestry has been removed from Villaviciosa to the Escurial, where an effort was made to establish an Arboretum, but this was interrupted; and the maintenance of a crown forest in a distant province, as a special school for practical instruction, has been abandoned. I have met with no indication of opinion in Spain, that the school in the Escurial has at 
auy period of its history suffered from not being adjacent to such a forest as is spoken of; and looking at the experience of schools of industry on the Continent, I am satisfied that there is no necessity for the organisation of a School of Forestry in Britain being clogged with the supposition that it must be located in a forest.

'The relative advantages of having forestry, including under that designation both forest science and forest economy, taught in isolated professional Schools of Forestry, and of having it taught by professors of forestry in Universities and other educational institutions of a like comprehensive character, has been exhaustively discussed in Germany, the birthplace of forestry and of modern Schools of Forestry; and an unequivocal expression of opinicn in favour of the latter arrangement was given at a Congress of German Foresters, held in the autumn of 1874 at Freiburg, in the Breisgau, in the Grand Duchy of Baden.

It was the third Congress of these which had beeu held in Germany, and it was numerously attended, more numerously than either of the preceding meetings, The members of the Congress were from all parts of Germany, and from countries adjacent: 134 were from Baden; 55 from Bavaria; 55 from Prussia; 41 from Wurtemburg; 35 from Alsace-Lorraine; 21 from the Central German States; 15 from Hesse; and there were besides 18 from Switzerland, 3 from Austria, and 1 from Russia -378 in all. In that number were 23 members who were not professional foresters; a large proportion of the authors of German works on forestry were there, and many Government officials entrusted with the administration of forest management in Prussia, Bavaria, Wurtemburg, Hesse, and Baden.

The president closen was Dr Nürdlinger, Forstrath, and then Professor of Forestry at Hohenheim.

Four subjects had been proposed for discussion, and the first of these was that above referred to, which was stated 
thus, 'Forstakadèmie oder Allgemeine Hochschule?' Forst Academie being the name given to isolated educational institutions designed exclusively for the study of forest science and forestry; Allgemeine Hochschule, the comprebensive desiguation given to colleges in which provision is made for a much more extensive and comprehensive course of study being followed, if desired, while attendance may be confined to specified classes if this be required or preferred.

Such Allgemeine Hochschulen are the following:-The Royal Academy of Land and Forest Economy at Hohenheim in Bavaria, in which there are three distinct departments of study:-1. Landwirthschaft, or Rural Economy, inclusive of asgriculture, horriculture, cattle breeding, \&c. 2. Forstwirthschaft, or Forest Economy in all its departments ; and 3. Grund-und-Hilfs-Wissenshaften, or sciences on which these are based, and sciences by which they may be advanced, including mathematics, physical science, technical arts, political economy, and jurisprudence. For the teaching of all of these there is provided a staff of protessors, \&c., with all necessary appliances. And the Polytechnic School at Carlsrube, in the Grand Duchy of Baden, in which there is cmbodied-1. A school of mathematics. 2. A school of engineering. 3 . A school of machinery. 4. A school of architecture. 5. A school of forestry. For the teaching of all these there is provided a staff of forty-nine professors, lecturers, college tutors, and assistants, with all necessary appliances. And the designation is susceptible of such distention as to include universities.

The interest created by this discussion was great and wide-spread. Buth official* and private reports of it were published.

For the following information I am indebted to an account of the Congress furnished by Herr J. Lehr to the Allgemeine Forst-und Jagd Zeitung, edited by Professor Dr Gustav

Bericht uber die IIl. Versammiung deutscher F'orstmänner zu Freiburg 1. B. Voю lbis. J. Suptember, 1374, py. $11: 2$ S*o. Berlin, 137J. Verlag von Julius springer. 
Heyer, Director of the Forest Academv of Muinden, in Havover, and Privy Councillor of the kingdom of Prussia. The question gave occasion for a discussion occupying six hours, which was condueted with ability, and listened to ihroughoul with marked attention, the sederunt, com:uencing at $S$ A.M., being continued with an hour's interval till three o'clock in the afternoon. It appears to have been a continuation or resumption of a discussion of the same subject at Hiihlhausen the year before. Two distinguished students of forest science had been appointed to open the discussion by reading papers, each stating the case in favour of that one of the arrangements which he approved.

The discussion was opened by Oberforstmeister Professor Dankelmanu, Professor of the School of Forestry at Neustadt-Ebers walde, in Prussia, defending the organisation of forest academies in preference to the substitution for these of arrangements for the study of forest science in Universities or.other seats of learning.

The second speaker appointed to open the discussion was Dr Von Seckendorff, from Austria, Professor and Councillor of State, who spoke in support of the proposal to combine Schools of Forestry with Hochschulen in which other studies were prosecuted, and stated-in reference to in allegation which had been made, that the movement laul originated entirely with professors and candidates for professors' chairs, and not with practical foresters, or furest administrators-that the opinion held by him he had found shared by numerous forest officials with whon he hari been brought into contact in other lands, and more especially by those of them who had studied at forest academies, a very great majority of whom had spoken of a combination of Schools of Forestry with the Hochschulen as a thing demanded by the honourable stanting of forest science and of the forest service.

Before the introducers of the discussion had commenced the delivery of their addresses, several gentlemen, all from Prussia, had anuounced their intention to speak in 
defence of the maintenance of the special professional schools. It was now proposed, and agreed to, that as in the meantime a great many friends of the Allgemeine Hochschule had added their names to the list of intending speakers, speakers pro et contra should alternately address the meeting.

There spoke in succession Dr R. Hartig, Professor in Neustadt-Eberswalde, in Prussia ; Oberförster Heiss, from Neustadt, in the Palatinate; Oberförster Ilse, from Beurig-Saarburg, near Treves; Forstmeister Ganghofer, from Würtzburg, in Bavaria; Forstmeister Bando, from Neustadt-Eberswalde, in Prussia; Dr Borggreve, Professor in Bonn (Poppelsdorf), on the Rhine. Dr Lothar Meyer, Professor in Carlsruhe, in the Grand Duchy of Baden; Dr Gerstner, Professor in Würtzburg, in Bavaria; and Professor Dankelmann replied.

Thereafter the President desired those who wished to give their vote in favour of professional school instruction in forestry being combined with that given in the Allgemeine Hochschulen to stand up, when the whole assembly seemed to rise with loud cheering. Then those who were in favour of the continued maintenance of separate Schools of Forestry were requested to stand up, when sixteen members only of the assembly stood up. Thus was the decision of the Congress given in favour of the former arrangement. 


\section{CHAPTER IV.}

\section{FORESTAL LITELIATURE.}

Uxique as may be our position among the uations of Europe, in not having either in Britain or in any of our Colonies, a School of Forestry, or provision for the study of Forest Science, beyoud arrangements made for candidates for employment in the Forest Service of India, which have been latterly introduced into the College of Engineering at Cooper's Hill, our position is scarcely less unique in regard to forest literature.

In my Plea for the creation of a School of Forestry in connection with the Arboretum, published in 187\%, in illustration of the difference in the amount of literature existing in our language and iu the language of Contiuental Europe, and as indicative of the magnitude of the change which is passing over different lands in which the English. language is the language of the people, I asked to be allowed to make the following statement, though in its commencement personal to myself :-

'I went to the Cape of Good Hope to act as Colouial Botanist in the beginniug of 1863 . On my arrival I was ufficially informed that the office had been created soms five years before with the two-fold object (1) of ascertaining and making generally known the economic resources of the Colony, as regards its indigenous vegetable productions, and its fitness for the growth of valuable exotic trees and other plants; and ( 2 ) of perfecting our knowledge of the flora of South Africa, and thus contributing to the advancement of botanical science.

' On making my first tour of the Colony to see its flora and its capabilities, I found myself face to face with a 
ditticulty in the way of the developement of these capabilities, arising from a reckless destruction of forests and of forest products which was going on, and a progressive desiccation of the climate, accompanying or following the destruction of forests and the burning of herbage and bush in connection with agricultural operations and pastoral husbandry. And I knew not then, nor do I know now, of a single work published in England from which I could then have procured informatiou in regard to the treatment required by aboriginal forests, to secure their conservation and improvement, excepting Forests and Gardens of South India, by Dr Cleghorn, then Conservator of Forests in the Madras Presidency; The Forester, by Dr James Brown; the Arboretum et. Fruticetum Eritannicur, by Louden; and English Forests and Forest Trees, an anonymous work published by Ingram, Cooke, \& Co., London. But none of these supplied the information I required.

'Contrast with this the richness of continental languages in literature on such subjects. I have had sent to me lately Ofversight af Svenska skogsliteraturen, Bibliografistia Studieren af Axel Cnattingius, a long list of books and papers in Forest Science published in Sweden; I have also had sent to me a work by Don José Jordana y Morera, Ingenero de Montes, under the title of Apuntes Bibliographic Forestale, a catalogue raissoné of 1126 printed books, MSS. dc., in Spanish, on subjects connected with Forest Science.

'I am at present preparing for the press a report on measures adopted in France, Germany, Hungary, and elsewhere, to arrest and utilise drift-sand by planting them with grasses and trees; and in Der Europaeische F'lug sand und seine Kultur, von Josef Wessely General-Domaenen-Inspektor, and Forst-Academie-Direltor, published in Vienna in 1873, I tind a list of upwards of 100 books and papers on that one department of the subject, of which 30 , in Hungarian, Latin, and German, were published in Hungary alone.

'According to the statement of one gentleman, to whom application was made by a representation of the Government at the Cape for information in regard to what suit- 
able works on Forest Economy could be procured from Germany, the works on Forst-Wissenschaft, Forest Science, and Forst-Wirthschaft, Forest Economy, in the German language, may be reckoned by cartloads. From what I know of the abundance of works in German, on subjects connected with forestry, I am not surprised that such a report should have been given. And with the works in German may be reckoned the works in French

'In Hermann Schmidt's Fach Katalogue, published in Prague last year (1876), there are given the titles, \&c., of German works in Forst-und Jagd-Literatur, published from 1870 to 1875 inclusive, to the 31st of October of the latter year, amounting in all to 650 , exclusive of others given in an appendix, containing a selection of the works published prior to 1870. They are classified thus:General Forest Economy, 93 ; Forest Botany, 60 ; Forest History and Statistics, 50 ; Forest Legislation and Game Laws, 56; Forest Mathematics, 25; Forest Tables and Measurements. \&c., 148; Forest Technology, 6 ; Forest Zoology, 19; Peat and Bog Treatment, 14; Forest Calendars, 6; Forest and Game Periodicals, 27 ; Forest Union and Year Books, 13 ; Game, 91 ; Forestry and Game in Bohemian, 44-in all, 652. Upwards of a hundred new books published annually. Amongst the works mentioned is a volume entitled Die Literatur des letzten sieben Jahre (1862-1872) aus dem Gesammtgebiete der Land und. Forst-wirthschaft mit Einschlusz der landw. Gewerbe u. der Jagd, in Deutscher, Franzosischer u. Englisher Sprache He:ausg, v. d. Buchhandl. v. Gerold \& Co., in Wien, 1873, a valuable catalogue of 278 pages in large octavo.

' Since the time of which I have spoken, fifteen years ago, a change has manifested itself in the different lands in which the English language is spoken. By an order of the House of Commons, dated 17th August, 1871, there was printed the "Return to an address of the House, dated 15th May of the same year: a selcction of dispatches and their cnclosures to and from the Secretary 
of State for India in Council, on Forest Conservancy in India, showing the measures which have been adopted, and the measures which are going on, in the several presidencies and lieutenant-governorships, beginning with the dispatch from the Governor-General in Council, of 21 st day of May, 1862 , to the present time." And the Return comprises two printed volumes, consisting of 1671 folio pages on India, one of 441 pages on Madras, and one of 357 pages on Bombay -in all, 2469 pages folio. And they report an approved estimate of expenditure, for the year 1871-1872, on forests in the Indian Empire of $4.5,11,000$ rupees, and an estimated income of $57,34,000$ rupees; or, according to another account, an annual expenditure of upwards of $\mathfrak{L} 4.50,000$, with annual returns of upwards of $£ 570,000$.

'In 1871 a commission was appointed by the Governnent of Victoria to report aniongst other things on the best means of promoting the culture, extension, and preservation of State Forests in Victoria, and the intruduction of such foreign trees as may be suitable to the climate, and useful for industrions purposes, which Committee has gone to considerable expense and trouble in collecting and printing information from New Zealand, India, the United States, Hanover, Prussia, Sasony, Bavaria, Austria, Baden, Italy, and Sweden, as well as Great Britain, availing themselves largely of the published report by Captain Campboll Walker on State Forest; and forest management in Germany and Austria, which I have cited in speaking of the Forest Schools of Germany.

'In the Report of the Commission of Agriculture, laid before the Senate and the House of Representatives of the United States, in 186.5, there was embodied a Memoir on "Aınerican Forest.s-their Destruction and Preservation," by the Rev. Frederick Starr, of St. Lonis, Missouri, of which Report 16.5,000 copies were orlered by the Honse of Representatives to be printed, and within a week 20,000 "extra copies "were ordered by the Senate.' 
The work by Sennor Jordana cited in this quotation was published in 1875, and referred, as has been stated, to works which had appeared in Spain previons to 1860 .

Apart from the forestal literature which was in existence in Spain previous to the establishment of a School of Forest Engineers, there has been issued in connection with demands felt in connection with operations resulting: from that enterprise, numerous works on subjects connected with Forest Science and modern Forest Economy. There have been given in a preceding chapter [ante pp. 136-143] the titles of a hundred and fifty of these, with the dates of publication, and the names of the writers - forty-two in number-all of which works may be considered works designed to meet a felt want; and most of them have been published within the last ten years.

We cannot compare with such progress; but a beginning has been made in the publication of similar works in nur language.

The "Plea" issued by me was published in the spring of 1877. Within a month thereafter there was issued the first number of the Journal of Forestry. The first paragraph of the Introductory Editorial Notes urged the establishment in the British Islands of a School of Forestry. From that day till the close of the publication of the periodical with the issue for April last, prominence has been given to this matter in the pages of that journal; and in it valuable contributions have been made to the forest literature of our country. Long before that there had been organised the Scottish Arboricultural Socicty; one of the first subjects brought before them was the expediency of securing some such institution, and with like pertinacity to that of the Journal of Forestry, the published transactions of the Society have urged this ineasure, and added to our stores of information in regard to forests and forest operations in Scotland. During the period within which these transactions have heen pub- 
lished repeated new and enlarged editions have appeared of The Forester: a Practical Treatise on the Planting, Rearing, and General Management of Forest Trees, by Dr James Brown, lately deceased, one of the fathers and founders of the Society.

This work of Dr James Brown constitutes a kind of connecting link between the past and the present. It is likely long to hold its place as an authority on the subjects of which it treats-different from, but related to, other matters brought forward in connection with the advanced forest science of the day, but gracefully, and of right, taking its place amongst these. And something similar may be said of many other works, published in Great Britain both before and since; prominent amnngst which are some of the works of Louden.

It may have been noticed that amongst the forestal works published in Spain, within the last fifteen years, are many preparel in acrordance with the arrangement in connection with the School, whereby professors and others are commissioned to visit foreign lands, on special errands relating to some one or more departments of research or of practical operations pertaining to forestry ; and to report the results, for consideration in connection with corresponding researches or forestal operations carried on in Spain, provision being made for their expenses being paid by the State, and for the report being published at the expense of the State, if this be reconmended by the Facultative Junta, and approved by the Minister of State entrusted with the cognisance of the School.

Some years ago, in the Scottish Arboricultural Society, there was mooted by $\mathrm{Mr}$ Hutchieson of Carlowrie, one of the vice-presidents of the Society, the project of an International Forestry Exhibition; and when the project was carried into effect it was with a view to promote a movement for the establishment of a National School of Forestry in Scotland, as well as with a view of furthering and stimulating a greater improvement in the scientific 
management of woods in Scotland and the sister countries which has manifested itself during recent years.

At the meeting at which the movement for the accomplishment of this was formally initiated, all of those who were present formally pledged themselves to give their best efforts and endeavours to render the Exhibition a success, and of such importance and general interest as to make it worthy of the name of International. In redemption of this pledge I published popular treatises on the folluwing subjects:-

\section{I.-Introduction to the Study of Wodern Forest Economy.}

In this there are brought under consideration the extensive destruction of forests which has taken place in Europe and elsewhere, with notices of disastrous consequences which have followed-diminished supply of timber and firewood, droughts, floods, landslips, and saud-drifts-and notices of the appliances of Modern Forest Science successfully to cuunteract these evils by conservation, planting, and improved exploitation, under scientific administration aud management.

II.-The Forests of England; and the Management of them in Bye-gone Times.

Ancient forests, chases, parks, warrens, and woods, are described; details are given of destructive treatment to which they have been subjected, and of legislation and literiture relating to them previous to the present century.

\section{III. - Forestry of Norway.}

There are described in successive chapters the generil features of the culnutry. Details are given of the geographical distribution of forest trees, followed by discussions of conditions by which this has been determined-heat, moisture, soil, and exposure. The effects of glacial action on the contour of the country are noticed, with accounts of existing glaciers and snow-fields. And information is supplied in regard to forest exploitation and the transport of timber, in regard to the export timber trade, to public instruction in sylviculture, and to forest administration, and to ship-building and shipping.

IV.-Finland: its Forests and Forest Management.

In this volume is supplied information in regard to the 
lakes and rivers of Finland, known as The Land of a Thousand Lakes, and as The Last-born Daughter of the Sea; in regard to its physical geography, including notices of the contour of the country, its geolugical formations and indications of glacial action, its flora, fauna, and climate; and in regard to its forest economy, embracing a discussion of the advantages and disadvantages of Svedjande, the Sartage of France, and the Koomaree of India; and the details of the development of Modern Forest Economy in Finland, with notices of its School of Forestry, of its forests and forest trees, of the disposal of its forest products, and of its legislation and literature in forestry are given.

\section{V.-Forest Lands and Furestry of Northern Russia.}

Details are given of a trip from St. Petersburg to the forests around Petrozavodsk on Lake Onega, in the government of Olonetz; a description of the forests on that government by Mr Judrae, a forest official of high position; and of the forests of Archangel by Mr Hepworth Dison, of Lapland, of the land of the Samoides and of Nova Zembla; of the exploitation of the forests by Jurdinage, and of the evils of such exploitation; and of the export timber trade, and disposal of forest products. In connection with discussions of the physical geography of the region information is supplied in regard to the contour and general appearance of the country; its flora, its forests, and the palæontological botiny of the regions beyond, as viewed by Professor Heer and Count Saporta ; its fauma, with notices of game, and with copious lists of coleoptera and lepidoptera, found there by Forst-Meister Gunther, of Petrozavodsk.

\section{VI.-Forestry in the Mining Districts of the Ural Mountains in Eastern Russia.}

Intormation is in this volume supplied in regard to forest exploitation in the government of Ufa; an account of the country passed through in a journey thither from St. Petersburg, and of mishaps and difficulties experienced in travelling there; information in regard to the country and people to the east of the Ural Mountains; the metallurgic works there established; the mines and forests in the Ural Mountain Range ; the forest exploitation of the region; abuses practiced in connection with this; and conditinus occasioning a diminishod supply of wood; with glimpses of life in the district ; of the cou- 
ditiou of the labouring population ; and notices of the Russian couquest of Siberia.

VII.-Forests and Forestry in Poland, in Lithuania, in the Ukraine, and in the Baltic Provinces of Russia; with Notises of the Export of Timber from Memel, Dantzig, and Riga.

In relation to Poland information is supplied in regard to the journey thither from St. Petersburg; the history of Polaud ; the area, distribution, management, exploitation, and produce of the forests in the Vice-Royalty ; its Suhools of Furestry; and forestal literature. In relation to Lithuania information is supplied in regard to the country and its people, and the Jewish population, who traffic largely in forest produce; in regard to the forests of the Dnieper; forest exploitation ; and forest game. There follow accounts of the forests of the Ukraine, and of the appearance of the country ; of the timber exports by the Baltic; and the forest lands, forest administraticn, and general appearances at different seasons of the Russian Baltic Provinces of Courland, Iivonia, and Estonia.

VIII._French Forest Ordinance of 1669 ; with Historical Shetch of Previous T'reatment of Forests in France.

The early history of forests in France is given, with details of devastations of these going ou in the first half of the seventeenth century ; with a translation of the Ordinance of 1669 , which is the basis of modern forest economy; and notices of forest exploitation in Jardinage, in La Methode ä Tire et Aire, and in La Methode des Compartements.

Besides these, I had previously published on subjects connected with Forest Science and Forest Economy :--

I.-Pine Plantations on Sand Wastes in France.

In this are detailed the appearances presented by the Landes of the Gironde before and after culture, and the Landes of La Sologne; the legislation and literature of France in regard to the plinting of the Landes with trees; the characteristics of the sind wastes; the natural history, culture, and exploitation of the nuaritime pine, and of the Scots fir; and the diseases and injurious influences to which the maritime pine is subject. 
II.-Reboisement in France; or, Records of the Re-planting of the Alps, the Cevennes, and the Pyrenees, with Trees, Herbage, and Bush, with a vicu to arresting and preventing the destrurtive consequences of torrents.

In this are given a resumé of Surell's study of Alpine torrents, of the literature of France relative to Alpine torrents, and of remedial measures which have been proposed for adoption to prevent the disastrous consequences following from themtranslations of documents and enactments, showing what legislative and executive measures have been taken by the Government of France in connection with réboisement as a remedial application against destructive torrents-and details in regard to the past, present, and prospective aspects of the work.

\section{III.-Forests and Moisture ; or Effects of Forests on Humidity of Climate.}

In this are given details of phenomena of vegetation on which the meteorological effects of forests affecting the humidity of climate depend - of the effects of forests on the humidity of the atmosphere, and on the humidity of the ground, on marshes, on the moistare of a wide expanse of country, on the locial ritin. fall and on rivers-and of the correspondence between the distribution of the rainfall and of forests-the measure of correspondence between the distribution of the rainfall and that of forests-the distribution of the rainfall dependent on geographical position, or determined by the contour of a country -the distribution of forests affected bo the distribution of the rainfall-and the local effects of frrests on the subsequent distribution of the rainfall within the forest district.

IV.-Hydrology of South Africa; or Detuils of the Former Hydrographi: Condition of the Cape of Good Hope, and of Causes of its Present Aridity, with Suggestions of Appropriate Remedies for this Ariditity.

In this the desiccation of South Africa, from pre-Adamic times to the present day, is traced by indications supplied by geological formations, by the physicai geography or the general contour of the country, and by arborescent productions in the interior, with results confirmatory of the opinion that the appropriate remedies are irrigation, arboriculture, and an improved forest economy : or the erection of dams to prevent the escape of a portion of the ritinfall to the sea-the abandon- 
ment or restriction of the burning of the herbage aud bush in convection with pastoral and agricultural operations-the conservation and extension of existing forests-and the adoption of measures similar to the réboisement and gazonnement carried out in Frauce, with a view to prevent the formation of torrents, and the destruction of property occasioned by them.

V.-Water Supply of South Africa, and Facilities for the Storage of it.

In this volume are detailed meteorological observations on the humidity of the air and the rainfall, on clouds, and winds, and thunder-storms; sources from which is derived the supply of moisture which is at present available for agricultural operations in the Colony of the Cape of Guod Hope and regions beyond, embracing the atmosphere, the raiufall, rivers, fountains, subterranean streams and reservoirs, and the sea; and the supply of water and facilities for the storage of it in each of the divisions of the colony-in Basutoland, in the Orange River Free States, in Griqualand West, in the Transvaal 'Territory, in Zululand, at Natal, and in the Transkei Territory.

In view of the requirements of South Africa, with a view to the development of its agricultural capabilities, I have also prepared and placed at the service of the Government and community of the Colony of the Cape of Good Hope, like reports to these on forestal engineering in Spain; on hydraulic engineering in Spain; on the forest industries of Spain; on the phylloxera inSpain, with details of the invasion of Europe by it, and reports of measures of defence adopted in different countries against its devastations; and on the locust in Spain and Southern Europe, Asia, Northern Africa, South Africa and America. Together with special reports on forestal, bydraulic, aud agricultural requirements of the Colony.

Amongst the reports procured by the Executive Committee of the Edinburgh International Forestry Exhibition is an exhaustive one on the forestal literature of other lands, and English works exhibited there, prepared by the jurors appointed to report on these. 
Not a little has been done by members of the forest service of India to make their acquirements of knowledge and of forestal skill subservent to the advancement of forestry in other lands besides India. Amongst other names which suggest themselves at once are those of $\mathrm{Dr}$ Cleghorn, Colonel Walker Campbell, Colonel Michael, and Colonel Pearson; and good service is being done by the Indian Forester, a valuable periodical.

It is impossible to speak in too high terms of treatises published by the late Baron Von Mueller, of Victoria. Most valuable practical information is embodied in Reports, Memoirs, and Manuals, issued by Mr J. E. Brown, Conservator of Forests for the Government of South Australia. And the forest reports annually published in various of our Colonies, and the official reports issued by the Government of the United States of Ainerica, are producing a large and valuable boly of forestal literature in the English language.

Besides these, many valuable treatises on subjects connected with forestry, and pertaining to forest science, have been published both in Britain and in America. Several of these are known to me, and highly valued by me, but I am not able to supply a complete list of the works which have been published; and it might seem invidious, and prove misleading, were I to give a partial list, and it is such alone which I could supply.

We have an extensive and valuable literature relative to Arboriculture. For this there is, and ever has been, a demand ; but with works on Sylviculture, Modern Forest Science, and Modern Forest Economy, it is otherwise. Nor is there yet such a demand for works of this kind as would make it pecuniarly remunerative to any to engage largely in the publication of such works; but as the demand increases so will the supply.

But a beginning lias been made. In so far as I have taken part in this 1 have done so in anticipation of a future demand, not in consequence of any manifestation of a felt want, And in reference to the rapid supply of 
works on forestry in the Spanish language of late years, which I have noted, I may remark that this did not occur until after several successive batches of studentshad entered upon the active duties of their profession. It was then that it became manifest wherein the existing forestal literature of the country was deficient in view of the requirements of the day; and that the desire for information inducel purchase and perusal. And it is noteworthy that even still in connection with the publication of almost all of the Spanish works referred to, including the most expensivo and least popular of them, the writers were relieved of the expense of publication. It is not so with us.

To quote again from my "Plea for the Establishment of a School of Forestry in connection with the Arboretum in Edinburgh ":-

'I have been asked-How has it come to pass that so little has been done in Britain, while so much has been done on the Continent of Europe, to raise up a body of foresters, highly educated for the discharge of their duties? My answer must be-Hitherto the problem to be solved in Britain did not require the amount of information which was required for the solution of the complicated problems demanding solution there. On the Continent they were threatened in many quarters with a lack of fuel, with a lack of timber, with ruinous desiccation, and with destructive torrents, all consequent on the de.truction of their forests, and with the devastation of fertile lands by drift sands, which could only be arrested and utilised by the planting of trees. In Britain we find fuel in our coal mines, and in many country districts in our peat bogs; excepting for a short time about the beginning of the present century, when war was raging, we could get timber of every description from beyond the sea; and we know little of drought, of torrents, and of drift sands, and the difference has even told upon our language. While our French neighbours speak of Sylviculture, the culture of woods, we speak of Arboriculture, the culture of trees, 
While they, in speaking of Les Forêts aud of La Code Forestiére, refer to a country covered more or less with trees, we, in speaking of The Green Wood and of Forestry, hitherto have thought chiefly of the game and of the chase, or of the shooting of deer. Our forest laws relate maiuly, if I may not say exclusively, to hunting, these law's having nothing to do with shrubs and trees, exceptin's in so far as they may supply shelter or covert for gitume. I speak advisedly when I say, that, according to the technical use of the term in English law, a forest need not contain a single tree, and a dozen of contiguous counties might be covered with trees without these constituting a forest. The totally different circumstauces in which the different countries have stood in regard to the requirements of forest products account for the difference in the attention hitherto given on the Continent and in Britain to the study of what is known there as Forest Science.

'It may be asked, seeing it is so - Why should we nut go on as we bave been doing hitherto? 'The answer isin our Colonies, and in the Indian Empire of India, evils which have existed long are being experienced and remedied; and those whom the country would engage to go forth to meet the evils must go, at the country's expense, to acquire the necessary education in other lands, and in a foreign language unknown to most young gardeners and foresters, and sons of foresters, whose life has been spent in connection with the management of trees, and which is so taught in many of our schools, that few even of the young men of our country who have had a liberal education could understand instruction given in it as they could instruction given in their own tongue.'

The pecuniary returns, I may add, are likely far to exceed in amount the expenditure likely to be incurred.

In the years 1860-64, during which years I held the office of Colonial botanist, and thus had my attentiou directed to this matter, the annual revenue derived from 
the whole of the Crown forests at the Cape of Good Hope

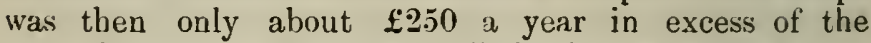
expeuditure on what was called the conservation, but included a wasteful sale of the produce; aud thereafter the free revenue rapidly diminished, and the forests were rapidly disappcaring. But latterly Count de Vassclot, an élève of the Forest School of Nancy, was appointed Commissioner of Forests in the Colony; and from a Colonial notice of an official report of his, it appears that these Crown forests, if regularly worked, would produce a yeurly revenue of $£ 235,000$ :

At the time referred to (1863-64) comparatively little was being done to obtain the greatest possible good from the Colonial forests of South Australia. In the interval the defence, exploitation, and extension of these forests has been entrusted to Mr J. E. Brown as Conservator of Forests. For eights years past there has been expended on these works, under his advice, well-nigh $\mathfrak{f} 6000$ a year; but this has been repaid within a small amount by revenue derived from the forests; while the value of the permanent improvements and extension of the forests is estimated at $£ 100,000$.

Again, from a statement in the Indian Pioncer, it appears that the Indian forest revenue for official year (1\$83-84) amounted to $£ 1,040,000$, and the charges to about $£ 600,000$, leaving a clear revenuc of $£ 440,000$. In France the revenue and expenditure of the forest department were $£ 1,405,104$ and $\mathfrak{E} 641,508$, according to a quotation by Dr Braudis. But the French State forests cover less than 4000 square miles. Those of the Indian Government, including the second-class reserves, cover over 89,000 square miles, and a large proportion of the expenditure in India is occasioned by extensive plantations. In Prussia, from 10,000 square miles of State forests, there is derived a net gain of nearly a million sterling annually.

THE END. 
. 


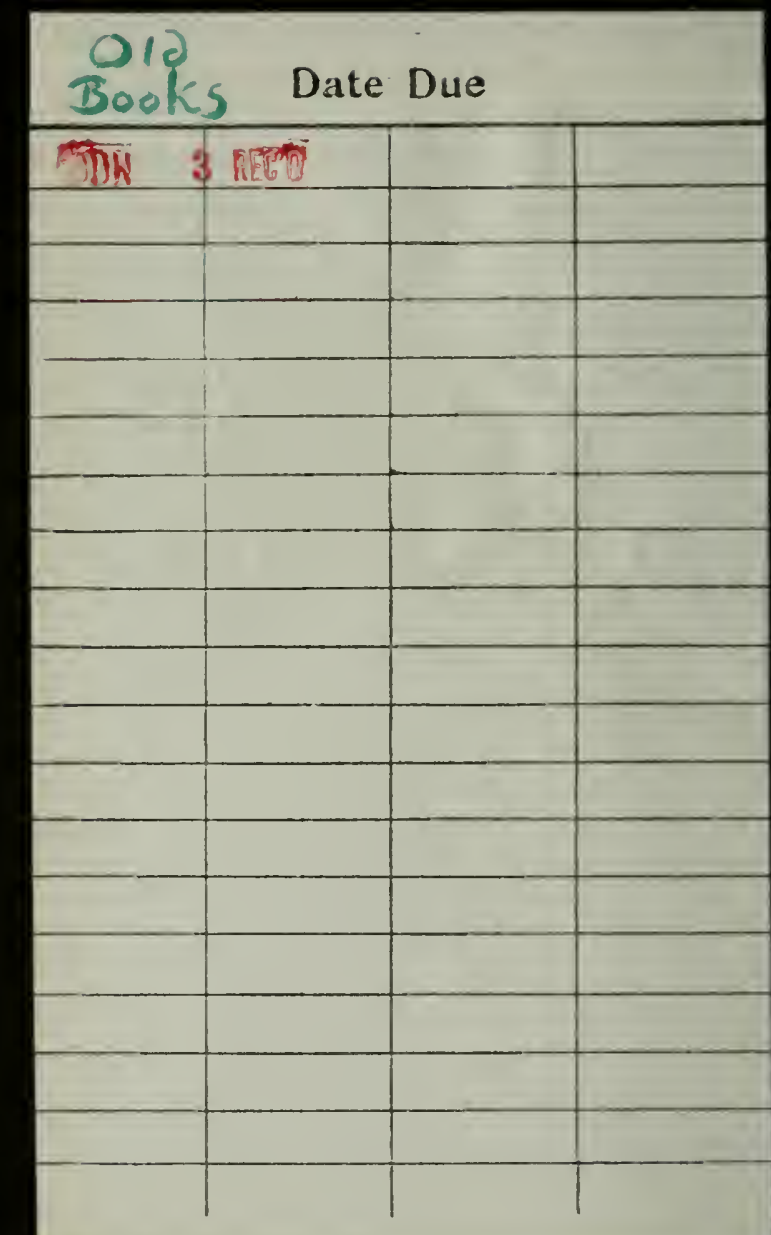




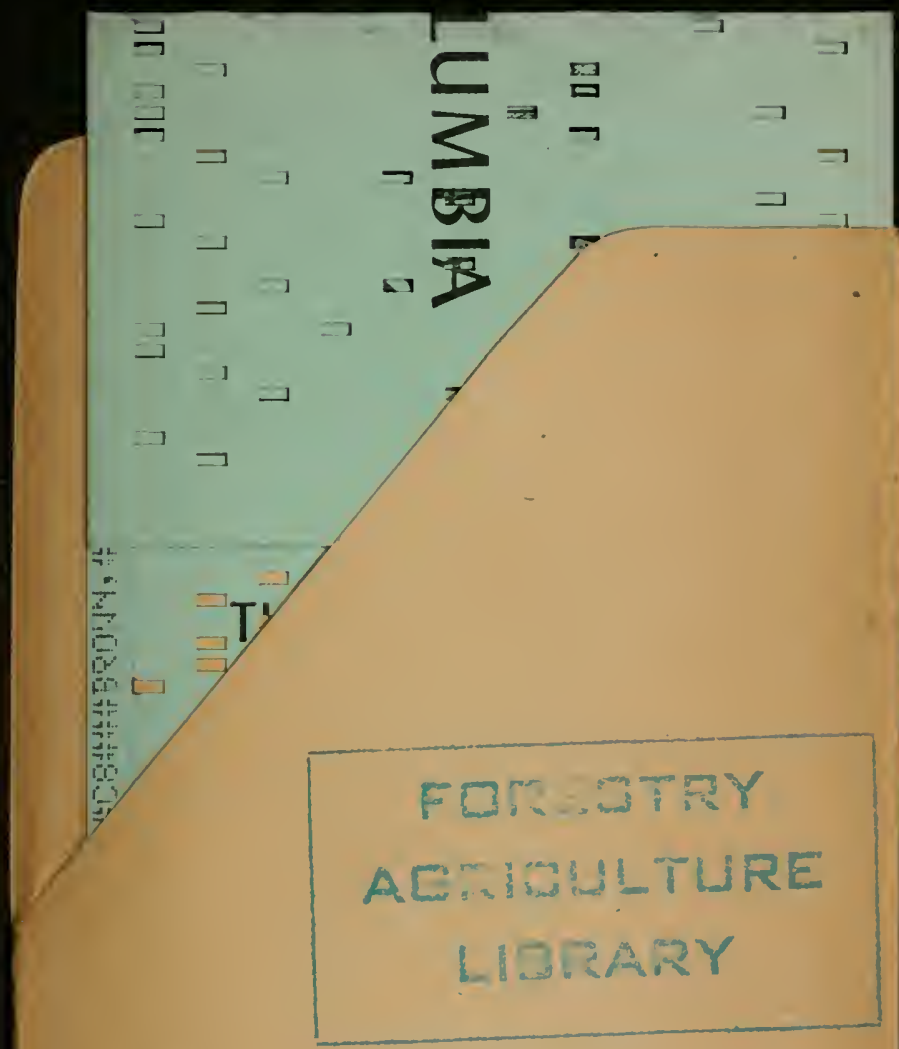


N.N.

$\frac{1}{1}$ 约

$\mathrm{AM}$ M

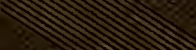

$6.9 \mathrm{~N}$ - N

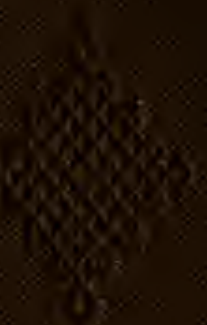

